\title{
Evaluation of Juvenile Salmonid Outmigration and Survival in the Lower Umatilla River Basin
}

\section{Annual Report}

\section{1 - 2002}

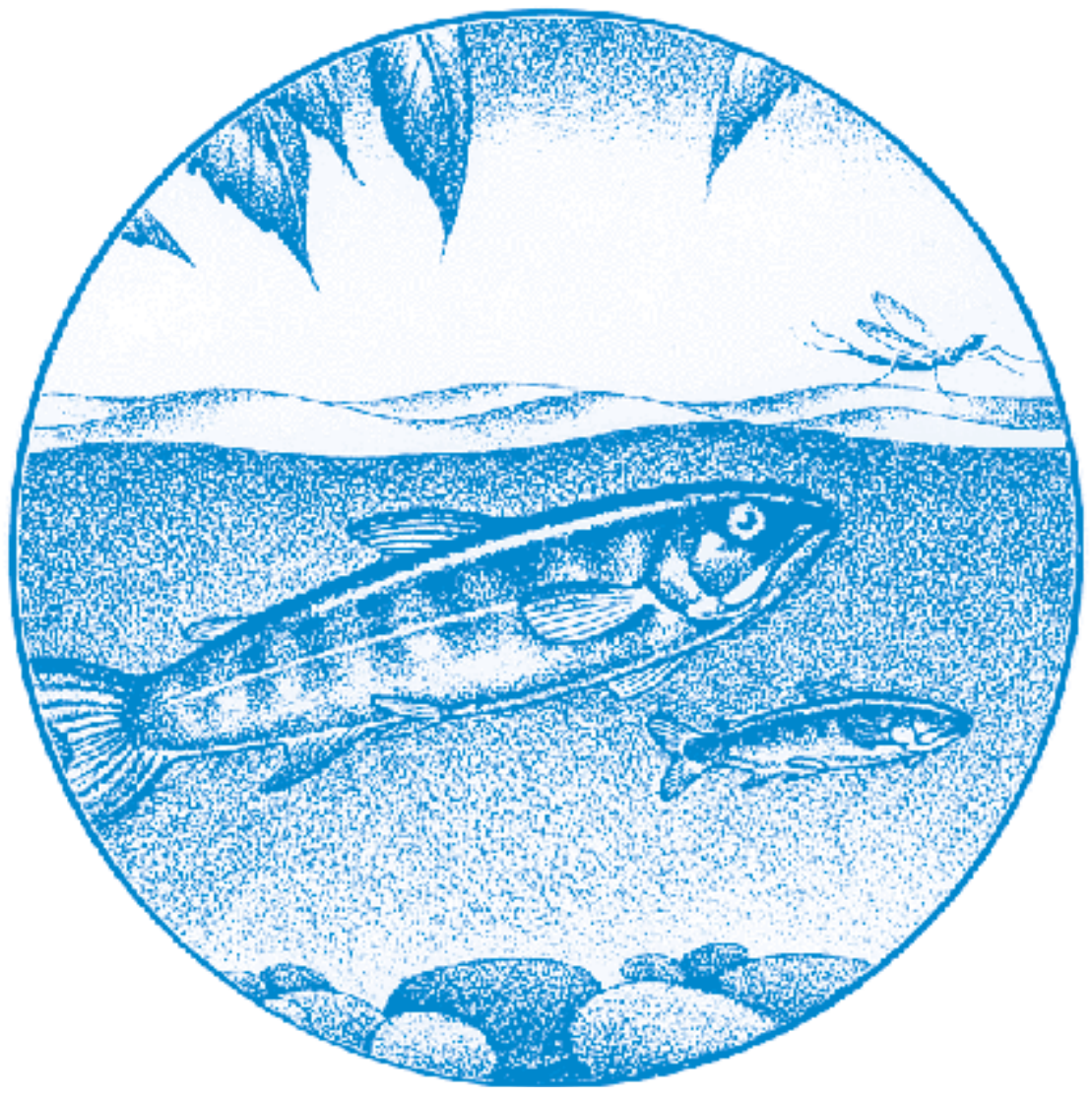

DOE/BP-00004340-4 
This Document should be cited as follows:

White, Tara, Josh Hanson, Shannon Jewett, Richard Carmichael, "Evaluation of Juvenile Salmonid Outmigration and Survival in the Lower Umatilla River Basin", Project No. 1989-

02401, 105 electronic pages, (BPA Report DOE/BP-00004340-4)

\author{
Bonneville Power Administration \\ P.O. Box 3621 \\ Portland, Oregon 97208
}

This report was funded by the Bonneville Power Administration (BPA), U.S. Department of Energy, as part of BPA's program to protect, mitigate, and enhance fish and wildlife affected by the development and operation of hydroelectric facilities on the Columbia River and its tributaries. The views in this report are the author's and do not necessarily represent the views of BPA. 


\title{
EVALUATION OF JUVENILE SALMONID OUTMIGRATION AND SURVIVAL IN THE LOWER UMATILLA RIVER BASIN
}

\author{
ANNUAL REPORT 2002 \\ (1 OCTOBER 2001 - 30 SEPTEMBER 2002)
}

\author{
Prepared by: \\ Tara C. White \\ Josh T. Hanson \\ Shannon M. Jewett \\ Richard W. Carmichael
Oregon Department of Fish and Wildlife
3406 N.E. Cherry Avenue
Salem, OR 97303-4924

Prepared for:

U.S. Department of Energy

Bonneville Power Administration

Environment, Fish and Wildlife

P.O. Box 3621

Portland, OR 97208-3621

Project Number 1989-024-01

Contract Number 00004340

January 2004 


\section{TABLE OF CONTENTS}

Page

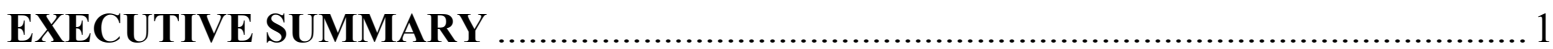

INTRODUCTION

STUDY AREA

METHODOLOGY …

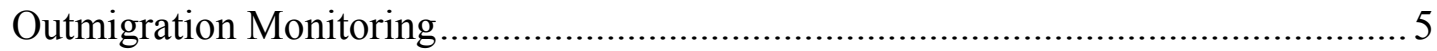

Fish Sampling and PIT-Tag Operations ………………........................... 5

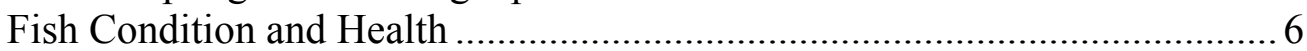

Migration Parameters..................................................................................... 6

Abundance and Survival...................................................................................

Migrant Abundance and Survival .............................................................. 7

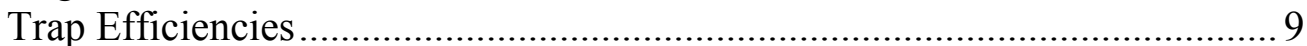

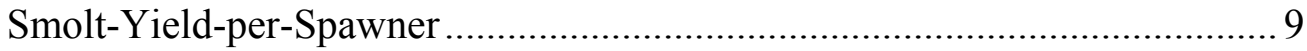

Transport Evaluation................................................................................. 10

Environmental Conditions and Fish Passage Operations ........................................... 10

Resident Species and Lamprey ………………………........................................... 11

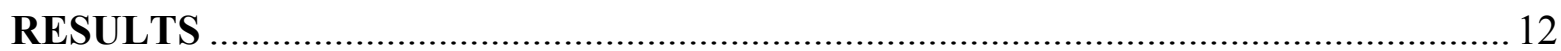

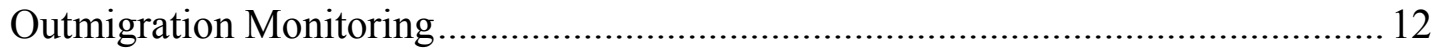

Fish Sampling and PIT-Tag Operations ................................................. 12

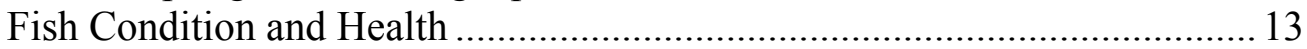

Migration Parameters................................................................................... 14

Abundance and Survival ............................................................................... 15

Migrant Abundance and Survival ......................................................... 15

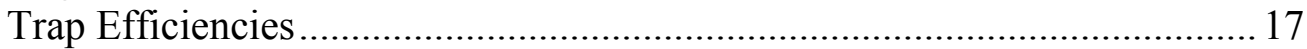

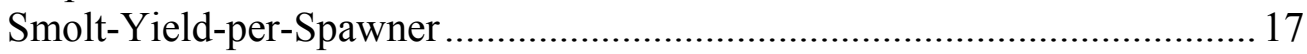

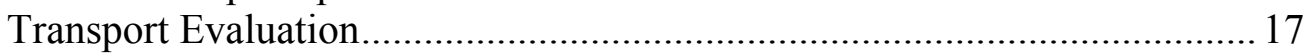

Environmental Conditions and Fish Passage Operations ....................................... 17

Resident Species and Lamprey ……………………….......................................... 19

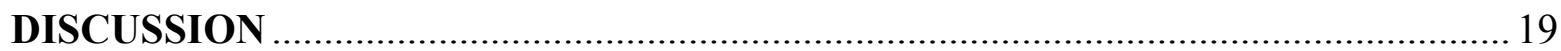

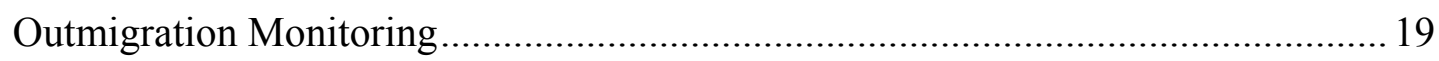

Abundance and Survival .................................................................................... 22

Environmental Conditions and Fish Passage Operations .......................................... 27

Resident Species and Lamprey ………………………............................................ 30 


\section{$\underline{\text { Page }}$}

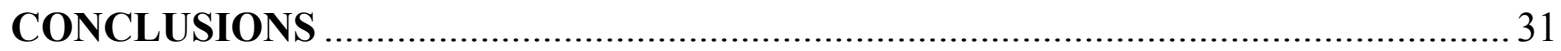

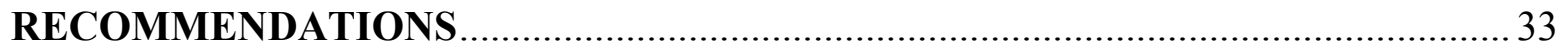

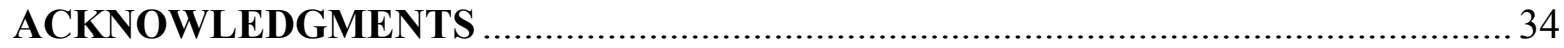

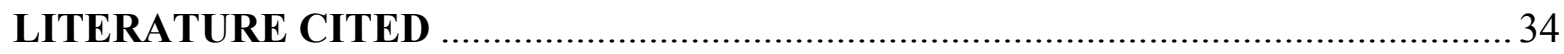

\section{LIST OF TABLES}

Page

Table 1. Summary of hatchery, rearing, acclimation and release strategies, Umatilla

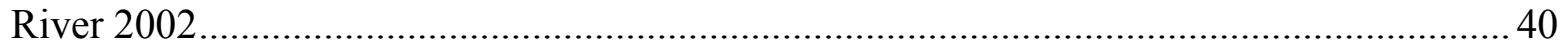

Table 2. Number of juvenile salmonids sampled and total passage index at RM 1.2 and 3.7,

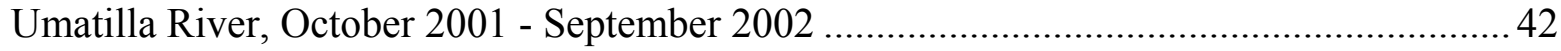

Table 3. PIT-tagged hatchery and natural production fish interrogated at RM 1.2 and RM 3.7, Umatilla River, February - September 2002 .......................................................... 43

Table 4. Detection efficiency and percent detection of juvenile salmonids interrogated at the east bank fish ladder of Three Mile Falls Dam (RM 3.7), October 2001 -

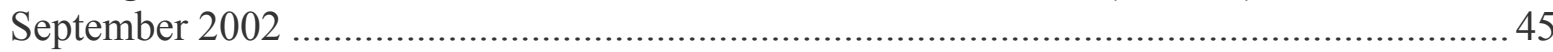

Table 5. Summary of scale loss for juvenile salmonids examined at RM 1.2 and RM 3.7, Umatilla River, October 2001 - September 2002 ….................................................... 46

Table 6. Summary of fish condition for juvenile salmonids examined at RM 1.2 and RM 3.7, Umatilla River, October 2001 - September 2002.

Table 7. Mortality rates for juvenile salmonids sampled at RM 1.2 and RM 3.7, Umatilla River, October 2001 - September 2002.

Table 8. Fork length ( $\mathrm{mm}$ ) summary of juvenile salmonids examined at RM 1.2 and RM 3.7, Umatilla River, October 2001 - September 2002

Table 9. Migration parameters of PIT-tagged hatchery salmonids monitored at RM 1.2 and RM 3.7, Umatilla River, October 2001 - September 2002 ………………………........ 51

Table 10. Migration parameters of natural salmonids passing RM 1.2 and RM 3.7, Umatilla River, October 2001 - July 2002

Table 11. Detection, abundance, and survival of PIT-tagged hatchery fish released into the upper Umatilla River and detected in the lower river, March - June 2002. 
Table 12. Binomial test for significant differences in detection of PIT tagged hatchery release groups, Umatilla River, 2002 ………………………………………………..... 56

Table 13. Monthly abundance estimates for natural fish sampled in the lower Umatilla

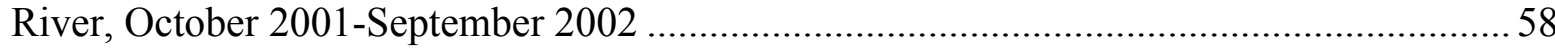

Table 14. Percent holding survival and tag retention of hatchery and natural juvenile salmonids tagged for trap efficiency tests at RM 3.7, Umatilla River, Spring 2002.

Table 15. Trap efficiency estimates, mean travel time, and detection information for hatchery and natural juvenile salmonids, West Extension Canal (RM 3.7), March-June 2002 .

Table 16. Smolt-yield-per-spawner of naturally-produced spring chinook salmon, fall chinook salmon and summer steelhead, Umatilla River, 2002. 66

Table 17. Summary of PIT-tagged hatchery subyearling fall chinook salmon released for trap and haul operations (transportation evaluation studies), Umatilla River, July 2002 .

Table 18. Correlation of daily fish passage index with river discharge and water temperature, Umatilla River, October 2001-September 2002

Table 19. Percent passage index for natural spring chinook salmon (NCHS), subyearling chinook salmon ( $\mathrm{NCH} 0)$, coho salmon (NCOH), and summer steelhead (NSTS) observed within given environmental categories. * represents significance $(P \leq 0.05)$

Table 20. Summary of linear regression analysis for trapping efficiency as a function of multiple environmental and operational variables ............................................................. 70

Table 21. Summary of Pacific lamprey captured at RM 1.2 and RM 3.7, $1995-2002 \ldots . . . . .71$

Table 22. Number of resident species captured at RM 1.2 and RM 3.7 and fork length summary statistics, Umatilla River, October 2001 - September 2002.

\section{LIST OF FIGURES}

\section{$\underline{\text { Page }}$}

Figure 1. Detailed study area map and release locations, Umatilla River 2002 ................... 72

Figure 2. Remote PIT-tag interrogation system (134 kHz) used at West Extension Canal

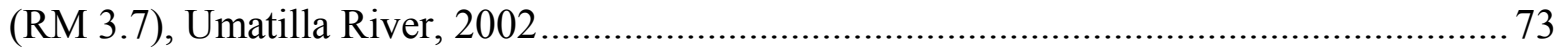


Figure 3. Temporary set up of portable detection system at east-bank viewing window, Three Mile Falls Dam (RM 3.7), Umatilla River, 2002 ...................................................... 74

Figure 4. Passage timing of hatchery yearling spring (HCHS) and fall chinook (HCHF) and natural spring chinook salmon (NCHS) versus river discharge (cfs), RM 1.2 and RM

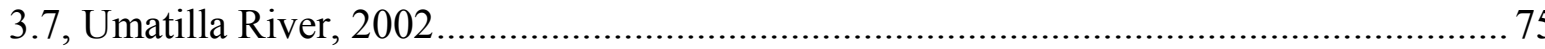

Figure 5. Passage timing of hatchery $(\mathrm{HCOH})$, unknown origin $(\mathrm{UCOH})$, and natural coho salmon ( $\mathrm{NCOH}$ ) versus river discharge (cfs), RM 1.2 and RM 3.7, Umatilla River, 2002 .

Figure 6. Passage timing of hatchery (HSTS) and natural summer steelhead (NSTS) versus river discharge (cfs), RM 1.2 and RM 3.7, Umatilla River, 2002 76

Figure 7. Passage timing of hatchery $(\mathrm{HCH} 0)$ and natural subyearling chinook salmon (NCH0) versus river discharge (cfs), RM 1.2 and RM 3.7, Umatilla River, 2002

Figure 8. Length-frequency distribution of yearling spring and fall chinook salmon captured at RM 1.2 and 3.7, Umatilla River, January -May 2002

Figure 9. Length-frequency distribution of coho salmon captured at RM 1.2 and RM 3.7, Umatilla River, March - June 2002

Figure 10. Length-frequency distribution of subyearling chinook salmon captured at RM 1.2 and RM 3.7, Umatilla River, May - July 2002 79

Figure 11. Length-frequency distribution of summer steelhead captured at RM 1.2 and RM 3.7, Umatilla River, March - June 2002 80

Figure 12. Percent and cumulative percent detection at RM 3.7 of PIT-tagged hatchery spring and fall chinook salmon from Umatilla Fish Hatchery (UFH), Willard National Fish Hatchery (WFH), and Bonneville Fish Hatchery (BFH), Umatilla River, March - May 2002.

Figure 13. Diel movement of PIT-tagged hatchery yearling spring and fall chinook salmon at RM 3.7, Umatilla River, March - May 2002.

Figure 14. Percent and cumulative percent detection at RM 3.7 of PIT-tagged hatchery subyearling fall chinook and coho salmon from Carson National Fish Hatchery (CFH) and Herman Creek Fish Hatchery (HCFH), Umatilla River, March - June 2002 ......................... 83

Figure 15. Diel movement of PIT-tagged hatchery subyearling fall chinook and coho salmon at RM 3.7, Umatilla River, March - June 2002 
Figure 16. Percent and cumulative percent detection of PIT-tagged hatchery summer steelhead (standard and extended reared) at RM 3.7, Umatilla River, April - June 2002 .... 85

Figure 17. Diel movement of PIT-tagged hatchery summer steelhead at RM 3.7, Umatilla

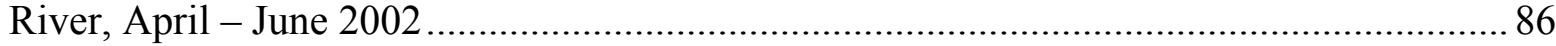

Figure 18. Mean weekly river discharge (cfs) and water temperature $\left({ }^{\circ} \mathrm{C}\right)$ at $\mathrm{RM} 2.1$, Umatilla River, October 2001 - September 2002

Figure 19. Mean weekly secchi depth (m) reading at RM 1.2 and 3.7, Umatilla River, October 2001 - July 2002

Figure 20. Mean daily discharge of McKay Reservoir water releases and Umatilla River discharge above and below the mouth of McKay Creek, Umatilla River, June 2002 - September 2002 88

Figure 21. Mean daily water temperature $\left({ }^{\circ} \mathrm{C}\right)$ of McKay Reservoir water releases and Umatilla River water temperature above and below the mouth of McKay Creek, October 2001 - September 2002. 88

Figure 22. Length-frequency distribution of juvenile Pacific lamprey sampled at RM 1.2, Umatilla River, November 2001 - March 2002 89

\section{LIST OF APPENDIX TABLES}

$\underline{\text { Page }}$

Appendix Table 1. Daily observations at RM 1.2, Umatilla River, October 2001 March 2002.

Appendix Table 2. Daily observations at West Extension Canal (RM 3.7), September 2001-October 2002

Appendix Table 3. ANOVA testing with transformed data for differences in juvenile survival between various release groups of spring chinook salmon, fall chinook salmon, and summer steelhead, outmigration years 1999-2002

Appendix Table 4. Summary of annual abundance estimates of natural juvenile salmonids emigrating the Umatilla River, 1997-2002 


\section{EXECUTIVE SUMMARY}

The year of 2002 represented the eighth year of a mutli-year project, monitoring the outmigration and survival of juvenile salmonids in the lower Umatilla River. This project both supplements and complements various ongoing and completed work within the Umatilla River basin. Knowledge gained on juvenile outmigration and survival assists researchers and managers in adapting hatchery practices, flow enhancement strategies, canal and fish ladder operations, and supplementation and enhancement efforts of natural and restored fish populations. Findings from this study also assist in assessment of the success of upriver habitat improvement projects and provide an overall evaluation of the Umatilla River fisheries restoration program.

General project objectives include: Evaluation of the outmigration and survival of natural and hatchery juvenile salmonids in the lower Umatilla River, in an effort to enhance the understanding of migration characteristics, survival bottlenecks, species interactions and effects of management strategies.

Specific objectives for 2002 included: 1). Operation of the remote interrogation system at Three Mile Falls Dam, West Extension Canal; 2). Design of improved PIT tag detection capabilities at Three Mile Falls Dam east bank adult fish ladder; 3). Estimates of migrant abundance, migration timing and in-basin survival of tagged juvenile salmonids representing various hatchery, rearing, acclimation and release strategies; 4). Monitoring of abundance and trends in natural production of salmon, steelhead and pacific lamprey; 5). Continuation of transport evaluation studies to evaluate the relative survival between transported and nontransported fish; 6). Assessment of the condition, health, size, growth and smolt status of hatchery and natural migrants; 7). Investigation of the effects of canal and fishway operations and environmental conditions on fish migration and survival; 8). Documentation of temporal distribution and diversity of resident fish species; and 9). Participation in planning and coordination activities within the basin and dissemination of results.

Key findings for 2002 revealed: (1) Migrant abundance of natural fish was roughly $10 \%$ that of hatchery produced fish; (2) An undetermined number of hatchery summer steelhead are residualizing in the upper Umatilla basin and potentially overwintering and migrating out as 2 year old smolts; (3) Transported fish may have a survival advantage over non-transported fish; (4) The later release of hatchery summer steelhead resulted in emigration timing that differed from that of naturally-produced fish; (5) Large-grade summer steelhead released lower in the river displayed improved survival over fish released higher; (6) Extended reared steelhead did not exhibit a survival advantage over standard reared fish; (7) Second year evaluation following reduction in the subyearling fall chinook program revealed survival to be similar to pre-reduction estimates; (8) Migration success was not improved nor in-river residence time reduced by acclimation of coho salmon at RM 56; (9) Early released spring chinook salmon migration and survival was unable to be evaluated due downstream monitoring facilities being in-operable during the early migration. 
Management Implications and Recommendations: (1) Natural salmonids should be PIT tagged in the upper Umatilla River in order to ascertain origin of migrating smolts, estimate outmigrant survival, and monitor trends in natural production; (2) Hatchery released steelhead should be closely monitored to assess the degree of suspected residualism and the impact releases may be having on natural populations; (3) Hatchery released coho salmon should be marked to differentiate between natural and hatchery smolts and help address management uncertainties; (4) Natural production goals for the Umatilla River should be reevaluated based on existing knowledge, habitat availability, current limiting factors, and basin capacity; (5) Improved PITtag interrogation capabilities should be implemented at the east bank fish ladder of Three Mile Falls Dam; (6) Additional research should be conducted to improve our understanding of flow exchange and McKay Reservoir releases on the various life stages of hatchery and natural salmonids.

\section{INTRODUCTION}

Historically the Umatilla River supported large runs of salmon (Oncorhynchus spp.), steelhead (O. mykiss), and Pacific lamprey (Lampetra tridentata) that provided productive Tribal and recreational fisheries. By the early 1920s, these runs were decimated. The extirpation and degradation of salmon and steelhead populations in the Umatilla River was a result of extensive agricultural development and associated water withdrawals, habitat destruction, water quality degradation, passage problems, over-harvest and habitat loss both inside and outside of the basin (Saul et al. draft 2001).

The Northwest Power Act of 1981 acted as a springboard for focusing attention and effort on restoring these once productive runs, throughout the Columbia River basin. The successive Fish and Wildlife Programs of the Northwest Power Planning Council (NPPC 1984, 1987, 1994) and the Comprehensive Plan for fisheries rehabilitation in the Umatilla River (Boyce 1986) articulated the necessary flow enhancement and fishery rehabilitation efforts required to restore anadromous fish populations in the Umatilla River basin. Efforts included such things as passage improvements at irrigation diversions, habitat restoration, initiation of hatchery production, construction of holding and acclimation facilities, flow enhancement efforts, and fish transport during low flows. Rehabilitation of anadromous fish stocks in the Umatilla River basin called for restoration of spring and fall races of chinook salmon (O. tshawytscha), coho salmon (O. kisutch), pacific lamprey and enhancement of summer steelhead production (CTUIR and ODFW 1989; Close 2002).

Many agencies contributed to the successful implementation of rehabilitation efforts in the Umatilla basin, including the Oregon Department of Fish and Wildlife (ODFW), the U.S. Bureau of Reclamation (USBR), Bonneville Power Administration (BPA), the National Marine Fisheries Service (NMFS), the Oregon Water Resources Department (OWRD), the Confederated Tribes of the Umatilla Indian Reservation (CTUIR), and various local irrigation districts (West Extension, Hermiston, Westland, and Stanfield). The Umatilla River Operations Group and the Umatilla Management, Monitoring and Evaluation Oversight Committee (UMMEOC) were created to coordinate river and fisheries management and research in the Umatilla River basin. The Umatilla Hatchery and Umatilla Basin annual operating plan (AOP) was developed to help guide the artificial production programs for the Umatilla River. Furthermore, construction of the 
subbasin plan (Saul et al. draft 2001) helped define the overall scope and nature of future goals and objectives in Umatilla River basin.

Over the past fifteen years, fisheries restoration efforts have resulted in increasing numbers of juvenile salmonid migrants and adult returns. Artificial production has increased through the Umatilla hatchery program and natural production has been enhanced through reintroduction efforts. Improvement in habitat, flows and passage facilities have further bolstered the fisheries restoration effort. Monitoring and research efforts to evaluate these specific restoration and enhancement projects were implemented. These efforts however, did not include an overall evaluation of the migration success and survival of hatchery-reared and naturally produced juvenile salmonids in the Umatilla River.

Long-term trend monitoring of juvenile abundance and survival was considered valuable as habitat was improved, flow enhanced, natural production expanded, and hatchery practices adjusted. In-basin survival needed to be addressed to answer critical uncertainties in the short term relative to overall survival in the long term. Monitoring and sampling in the lower river were considered crucial for gathering the necessary information regarding life history characteristics, lower river production, abundance, and smolt-to-adult survival of all natural salmonids. Specific questions still remained regarding in-basin survival and passage problems for juvenile fish, production potential for natural stocks, and aquatic community health. Furthermore, as production strategies evolved, results needed to be monitored and merits evaluated to help guide management decisions.

The Outmigration and Survival project was established in 1994 in attempt to address some of the above noted concerns. The project was intended to be long term and broader in scope than previous work, although concerns with juvenile fish passage at Three Mile Falls Dam still remained and needed to be addressed. Outmigration monitoring was originally conducted via branding and color-marked fish (Knapp et al. 1996, 1998a, 1998b). However the advent and installation of PIT tag technology at the John Day Dam in 1998, prompted the use of PIT (Passive Integrated Transponder) tags $(400 \mathrm{kHz})$ in the Umatilla River basin the same year. An upgrade to the $134 \mathrm{kHz}$ system in 2000, further enhanced monitoring capabilities. Five years of remote interrogation in the lower Umatilla River have provided improved migration, abundance and survival estimates of juvenile salmonids without the stress of handling. Remote detection capabilities have also greatly supplemented tag detections at mainstem Columbia dams and provided improved information on in-basin migration parameters.

Eighth year funding from BPA will: 1) Facilitate monitoring of tagged hatchery and natural juvenile salmonids in the Umatilla River basin, 2) Help define migration parameters, abundance, and survival of juvenile salmonids emigrating from the Umatilla River, 3) Clarify the effects of river and canal flow, water temperature, and other environmental variables on fish migration, and 4) Define the condition, health, size, growth and smolt status of hatchery and natural migrants; and 5) Aid in monitoring the movement of juvenile pacific lamprey. 


\section{STUDY AREA}

The Umatilla River basin is located within Umatilla and Morrow counties, of northeast Oregon (Figure 1). Draining an area of 2,290 square miles, it flows in a northwesterly direction into RM 289 of the Columbia River. The uppermost reaches of the basin are situated along the steep timbered slopes of the Blue Mountains of the Umatilla National Forest (ibid Saul et al. draft, 2001). The remainder of the drainage lies within the broad upland plain of the DeschutesUmatilla Plateau (Contour and Kissner 2000).

The Umatilla River contains a mainstem length of 115 miles (Contour and Kissner 2000) and is fed by eight (8) major tributaries. Elevation ranges from nearly 5,800 feet at the headwaters, to 260 feet at its confluence with the Columbia River (Saul et al., draft 2001). Identified by hydrologic unit number 17070103 (US Geological Survey, 1989), it receives a mean annual precipitation of 10 to $50 \mathrm{in}$./yr within the lower and upper basin, respectively (Contour and Kissner 2000; Saul et al. draft 2001). The Umatilla River subbasin lies within Oregon's North Central bio-geoclimatic zone (Zone 6).

The upper portion of the basin encompasses a section of the Umatilla National Forest as well as 172,000 acres of tribal land (Confederated Tribes of the Umatilla Indian Reservation). The majority of the land in the Umatilla basin is privately owned (82\%), with the remainder being divided amongst the State of Oregon, Umatilla County, various cities and CTUIR (ibid, Saul et al., draft 2001).

Specifically, the project area is situated within the lower Umatilla River mainstem, between RM 3.7 and RM 1.2 (Figure 1). The juvenile screening facility (inclined plane trap and PIT tag interrogation system) is located at RM 3.7 within West Extension Canal, immediately downstream of Three Mile Falls Dam. The secondary collection location (rotary screw trap) is situated at RM 1.2 in a deep pool beneath the Interstate 82 bridge. Sampling is conducted year round, with operations focusing at RM 3.7 between March and September and at RM 1.2 from October to February.

Release sites for trap and haul operations and trap efficiency tests are located at various points along the Umatilla mainstem. More specifically, the sites are situated between the mouth and RM 23 (Stanfield Bridge). The average monthly discharge within the lower river varies from a low of $23 \mathrm{cfs}$ in the summer (July) up to 1,095 cfs during spring runoff (April). Water temperatures have been known to peak at sub-lethal levels of between $18{ }^{\circ} \mathrm{C}$ and $27^{\circ} \mathrm{C}$ (Saul et al., draft 2001). 


\section{METHODOLOGY}

\section{Outmigration Monitoring}

\section{Fish Sampling and PIT-Tag Operations}

A rotary-screw trap and incline plane trap were utilized to capture emigrating juvenile salmonids from the Umatilla River. The rotary-screw trap was operated at RM 1.2 and the incline plane trap was situated at RM 3.7 in West Extension Canal. A detailed description of fish trapping and sampling operations can be found in White et al (2003). Origin of fish captured was categorized as "natural" or "hatchery" according to the presence or absence of an adipose fin, a worn appearance of the dorsal and ventral fins, or a wire tag.

All fish passing through the incline plane and rotary screw traps were interrogated for PIT tags (Figure 2). A full description of PIT tag interrogation, marking, and file management operations can be found in White et al (2003). Fish were tagged according to standards outlined in the PIT Tag Marking Procedures Manual (CBFWA, PIT Tag Steering Committee, 1999). The only notable change in PIT Tag operations during 2002 was an upgrade to the PITTag3 software program.

In addition to usual trapping and PIT Tag operations, a temporary remote interrogation system was also operated at the east-bank adult fish ladder of Three Mile Falls Dam to supplement juvenile tag detections and provide tag information on returning adults (Figure 3). Two 7" portable antennas were attached to the $3-1 / 2 \mathrm{ft}$ by $4-1 / 2 \mathrm{ft}$ glass viewing window. The glass is two inches thick and the fish passage channel behind the window is approximately one foot wide. Each antenna was connected to a PTS Model 2001F reader. Readers were set to store tag codes, which were regularly downloaded into an interrogation file and uploaded to the PTAGIS database.

Detection efficiency tests were conducted at the east-bank adult fish ladder of Three Mile Falls Dam throughout the emigration season. Four groups of yearling chinook salmon, 2 groups of subyearling fall chinook salmon, 2 groups of coho salmon, and 1 group of summer steelhead were used to test the detection capabilities of the temporary interrogation system. Coho salmon were of unknown origin, while all other fish were of hatchery origin. Individual groups were PIT tagged and held at West Extension Canal for 24 hours prior to release. Fish were transported in a 350 gal slip tank to the east-bank and released approximately 20 feet upstream from the interrogation site. Following detection, tag codes were placed in an interrogation file and then uploaded to the PTAGIS database. 


\section{Fish Condition and Health}

All natural emigrants and a subsample of 100 to 200 hatchery emigrants were examined on a daily basis to assess condition, size, smolt status, growth, and health. Descaling was categorized following criteria used by the Umatilla Hatchery Monitoring and Evaluation Project (Keefe et al. 1994). Single character descriptor codes were used to record observations of body injuries, external parasites, bird marks, fungal infections of the body surface, and bacterial kidney disease. Fork length was recorded to the nearest $\mathrm{mm}$ and development (smoltification) class was determined by brightness and the absence or presence of parr marks. Fish mortality was noted by species/origin type and identified as pre or post sampling. All dead natural fish and some diseased and dead hatchery fish were frozen and submitted to the ODFW Fish Pathology Lab for examination of fish health status.

The Spearman rank correlation test was used to analyze the possible relationship of fish condition with various independent variables. Independent variables included river discharge, water temperature, and secchi depth (water clarity). A nonparametric test was used because the assumption of bivariate normal distribution was not fulfilled. The Spearman rank correlation test was also used to assess relationships between fish size, period of peak emigration, and level of smoltification for hatchery emigrants.

Scale samples on a subsample of natural summer steelhead and spring chinook salmon were collected for age and origin analysis in cooperation with CTUIR. The growth in length $(\mathrm{mm} / \mathrm{d})$ for individual tagged fish was calculated as length at recapture minus length at tagging divided by the number of days between tagging and recapture.

\section{Migration Parameters}

Migration parameters were analyzed for hatchery juvenile salmonids using PIT tag detections at West Extension Canal. Parameters analyzed included emigration timing, duration, and travel speed for each species. Peak movement was determined by selecting the date when the maximum number of tagged emigrants were detected at the trap. Median emigration was the date when $50 \%$ of the tag detections were observed and diel movement was determined by the percentage of fish detected within hourly blocks of time. Travel speed was calculated for each tagged fish detected at West Extension Canal using the following equation:

$$
\mathrm{TS}=(\mathrm{RM}-3.7) / \mathrm{D}-\mathrm{R})
$$

where $T S=$ travel speed, $R M=$ river mile of release, $D=$ date and time of detection at West Extension Canal, and $R=$ date and time of force release. The median travel speed was calculated for each hatchery group using interrogated fish. Median rather than mean travel speeds were computed because detection distributions tended to be skewed. Negative travel speed estimates due to volitional movement of hatchery fishes were omitted from the analysis, as were tagged fish interrogated during fish sampling operations, due to the inability to assign an accurate date and time of detection.

A fish passage index was used to analyze the migration parameters of natural juvenile salmonids due to a reduced tagging effort in the upper basin. The fish passage index was the number of fish captured during a designated block of time expanded by the sampling rate. 
Designated blocks of time ranged from a few minutes to several hours and sample rates were between 1 and $100 \%$. The date when the first and last emigrant of each species was observed was determined along with peak movement and median emigration. Peak movement was determined by selecting the date when the maximum number of emigrants passed the traps. Median emigration was the date when $50 \%$ of the total fish passing the traps was observed.

\section{Abundance and Survival}

\section{Migrant Abundance and Survival}

Migrant abundance and survival was estimated for tagged hatchery fish and untagged natural fish leaving the Umatilla River basin. Migrant abundance of hatchery fish was estimated to monitor survival of specific hatchery release groups. Migrant abundance of natural salmonids was estimated to supplement tribal data and aid in monitoring of population abundance, natural production and smolt-to-adult survival.

\section{Abundance}

Migrant abundance of natural fish was estimated at West Extension Canal using the following equation:

$$
\begin{gathered}
A=B / T E \\
\text { and } \\
B=(C / T) / D
\end{gathered}
$$

where, $\mathrm{A}=$ estimated number of outmigrants, $\mathrm{B}=$ number of fish passing through the trap, $\mathrm{TE}=$ estimated trap efficiency, $\mathrm{C}=$ sample rate, $\mathrm{T}=$ proportion of time sampled, and $\mathrm{D}=$ diel pattern of fish movement.

Expansion factors used to calculate natural abundance differed at West Extension Canal and the rotary screw trap, due to the differing nature of the facilities and variations in sampling. Natural abundance at the rotary screw trap was estimated using a slight variation in the formula:

$$
\mathrm{A}=(\mathrm{C} / \mathrm{TR}) / \mathrm{TE}
$$

where, $\mathrm{A}=$ total number estimated outmigrants, $\mathrm{C}=$ the number of fish captured, $\mathrm{TR}=$ trap retention efficiency and $\mathrm{TE}=$ estimated trap efficiency. Sampling rate and time were not adjusted for due to $24 \mathrm{hr}$ a day trap operation.

Total abundance was estimated on a monthly basis and then summed to derive the total number of outmigrants for the season. For months where trap efficiencies of natural species were not available or were sparse, efficiency estimates from hatchery conspecifics were used to supplement the average estimate. If hatchery conspecifics were not available for a particular month, efficiency estimates from the month before or month after were used.

Trap efficiency and retention efficiency estimates for coho salmon were derived from 1997 and 1998 tests (Knapp et al, 1998b; Knapp et al 2000). Natural chinook salmon were assumed to be $100 \%$ retained in the rotary screw trap due to their small size. Since retention efficiency estimates were not available for natural or hatchery steelhead, a 50\% retention efficiency was assumed, based on a 77\% efficiency estimate for hatchery spring chinook (Knapp et al. 2000). Similarly, since trap efficiency estimates were also not available for natural or hatchery 
steelhead, a trap efficiency estimate of 1\% was applied, assuming the efficiency for natural summer steelhead would be around half that of yearling spring and fall chinook salmon (2.1 3.7\%; Knapp et al. 2000) due to their ability to avoid the trap (determined from sampling in 1997; Knapp et al. 1998b).

Abundance of hatchery fish was computed using methodology outlined in Burham et al. (1987) and Dauble et al. (1993), whereby:

$$
A=(D)(1 / T E)
$$

and, $\mathrm{A}=$ estimated proportion of tagged fish from specific release groups passing $\mathrm{RM} 3.7, \mathrm{D}=$ the number of tagged fish detected and TE = estimated trap efficiency. Since detections were date specific, efficiency estimates used encompassed corresponding tag dates. If efficiency estimates did not correspond to the dates tags were detected, trap efficiency data was arbitrarily pooled using the closest daily estimates before and after the detection date.

The Bootstrap method (Efron and Tibshirani 1986; Thedinga et al. 1994), with 1,000 iterations, was used to determine the variance and 95\% confidence interval for the abundance

estimate. Variances for abundance subtotals were summed to derive an overall variance for each release group and species. Confidence intervals (95\%) for the abundance estimate were calculated using the square root of the variance $(\mathrm{CI}=1.96 \sqrt{\mathrm{V}})$.

Survival

Migrant survival of hatchery fish was computed using the following equation:

$$
\begin{gathered}
S=A / R \\
\text { and } \\
A=(T D) /(1 / T E)
\end{gathered}
$$

where, $\mathrm{S}=$ survival, $\mathrm{A}=$ the outmigrant abundance at $\mathrm{RM} 3.7, \mathrm{R}=$ the number of tagged fish released at upriver sites, $\mathrm{TD}=$ number of tagged migrants recaptured downstream, and $\mathrm{TE}=$ estimated trap efficiency (Burham et al. 1987 and Dauble et al. 1993). The binomial test was used to test for significant differences in detection between individual release groups.

Survival was compared between various release groups and within each species of hatchery tagged fish (Table 1). Migrant survival comparisons included evaluation of optimal release sites and tactics, rearing strategies, and hatchery/broods.

Survival was unable to be estimated for natural species, due to the limited number of fish tagged. 


\section{Trap Efficiencies}

To calibrate the collection efficiency of the traps and estimate outmigrant abundance and survival, groups of 50 to 150 fish per species/release group were PIT-tagged and then released upstream of the traps for recapture. Fish captured at the rotary screw trap were also color marked following procedures outlined in Knapp et al. (1996). Tests were generally conducted 2 times per week for each species/release group while sufficient numbers of fish were being captured. Tagged fish were typically held for 24 hours to assess latent mortality (tagging effect), tag loss and determine the probability of survival of individual release groups. The probability of survival and estimated survival of tagged fish released was calculated using the following equations:

$$
\begin{gathered}
s=L / H, \\
\text { and } \\
M=N(s)
\end{gathered}
$$

where $\mathrm{s}=$ probability of survival, $\mathrm{L}=$ number of live tagged fish after holding, $\mathrm{H}=$ initial number of tagged fish held, $\mathrm{M}=$ estimated survival of tagged fish released, $\mathrm{N}=$ total number of tagged fish released. Tagged fish, which died or dropped their tags prior to release were removed from the test group. Tag retention and fish survival for all factors other than tagging were assumed to be $100 \%$ after release. Additional details regarding tagging, holding, and fish transport operations can be found in White et al. (2003).

Recaptured fish were enumerated by species/origin type and trap efficiency estimates were computed using the following formula:

$$
\mathrm{TE}=\mathrm{R} / \mathrm{M}
$$

where, $\mathrm{TE}=$ estimated trap efficiency, $\mathrm{R}=$ number of recaptured tagged fish, and $\mathrm{M}=$ number of tagged fish released and adjusted for survival. Separate trap efficiency estimates within a species were compared using $\mathrm{Chi}^{2}$ analysis and pooled if the estimates were not significantly different (P $\leq 0.05$ ). If less than five tagged fish of a particular release group were recaptured, adjacent test groups were pooled until the number of recaptures was greater than five. Pooling was continued until a significant difference was determined. The final trap efficiency estimate was the weighted mean of the pooled estimates.

\section{Smolt-Yield-Per-Spawner}

Natural smolt-yield-per-spawner (natural and hatchery) was estimated for naturally produced outmigrants. Smolt per spawner estimates were determined using the equation:

$$
\mathrm{SY}=\mathrm{A} / \mathrm{NS}
$$

where, $\mathrm{SY}=$ smolt yield, $\mathrm{A}=$ smolt abundance, and NS $=$ number of spawners.

Methodologies closely followed those outlined in Chess et al. (2003). The number of spawners for spring chinook salmon was based on the total number of redds counted during spawning ground surveys times two. Fall chinook spawner estimates were computed using the female spawning escapement at Three Mile Falls Dam times two. Escapement data was used to 
determine the number of spawners for natural summer steelhead. All spawning escapement and disposition data was derived from Contour and Kissner (2003) and Chess et al. (2003).

Steelhead data was presented by predominate smolt outmigration year (age $2+$ smolts). Age composition data from 1991-1996 was used to determine the primary migration age of naturally produced Umatilla steelhead (Chess et al. 2003).

\section{Transport Evaluation}

Transport evaluation (trap and haul) of hatchery subyearling fall chinook salmon was conducted the second week of July. Tests were conducted to determine relative survival of transported versus non-transported fish. Transported (treatment) fish were hauled to the mouth of the Umatilla River and released. Non-transported (control) fish were released directly beneath the Stanfield Bridge (RM 23).

Approximately 2,700 fish were PIT-tagged and held at the Irrigon Hatchery in indoor circular tanks $\left(12^{\circ} \mathrm{C}\right)$ for $30-45$ days. In July, fish were transferred from the hatchery to West Extension Canal. The holding tank at West Extension Canal was supplied with river water to gradually acclimate fish to ambient river temperatures $\left(18\right.$ to $\left.22.5^{\circ} \mathrm{C}\right)$ prior to release. Midsummer heat however, resulted in holding tank temperatures rising to between 19 and $26^{\circ} \mathrm{C}$.

Equipment difficulties at Westland (RM 27.2) precluded holding at the facility as was done in previous years. Fish were thus held at West Extension Canal and then transferred to Westland and held briefly in the pond to undergo the netting process (simulate trap \& haul) prior to release. Releases were made on a daily basis, during a one-week period. Non-transported (control) fish were released first, in five groups of approximately $300 \mathrm{fish} /$ release (1,500 fish). Transported (treatment) fish were released five days later, in groups of 200-300 fish/release (1,200 fish).

Lethal overnight holding temperatures $\left(26^{\circ} \mathrm{C}\right)$ on day three of the treatment releases resulted in the death of over half the remaining fish, preventing test completion. Remaining fish were in poor condition and thus not subjected to the Westland netting process. Instead fish were released directly at the river mouth. Tag detections from transported and non-transported fish groups were downloaded from the PTAGIS database and survival indices were compared.

\section{Environmental Conditions and Fish Passage Operations}

Physical and environmental conditions, including river discharge, flow augmentation, water temperature and water clarity were monitored throughout the season to characterize conditions in the Umatilla River and to assess their effects on fish emigration. Daily river discharge, flow augmentation from McKay Reservoir, and water temperature data was obtained from the USBR Hydromet Achieves: http://mac1.pn.usbr.gov/umatilla/umawebhydreadarc.html. Weekly mean discharge and temperature from the Umatilla gauging station (RM 2.1) was plotted against time. Weekly mean discharge and daily mean water temperature from McKay Reservoir was also plotted against time. Water clarity was measured to the nearest $0.05 \mathrm{~m}$ using a 7 -in-diameter Secchi disk. A mean depth was determined by averaging the depth at which the disk disappeared and reappeared as it was lowered and raised from the water. Weekly mean secchi depth was plotted against time. 
The relationship between river discharge and the number of emigrants passing a trap site (passage index) were tested using the Spearman rank correlation test. A separate test was run for each species/origin type. Spearman rank correlation test was also used to test for a relationship between water temperature and the number of emigrants passing a trapping site. The variable reflecting the river discharge or water temperature during the passage period was the average of the mean of the day before and the day of passage. The time period used for the analysis was between the day when the first and last emigrant was observed. Discharge and temperature variables from the Yoakum gauging station (RM 37.6) were utilized for the analysis. The Yoakum gauge is located below all anadromous fish bearing tributaries and hatchery acclimation facilities, is directly influenced by McKay Reservoir releases, and is located above any major irrigation diversion operations. Any missing discharge or temperature records were estimated by taking the average of the mean daily discharge or temperature three days prior and three days after the missing record.

In addition, a $\chi^{2}$ goodness-of-fit test was used to analysis the proportion of the emigration (passage index) of natural juvenile salmonids that occurred within a given environmental range. For river discharge, five ranges reflecting the percent change from the previous day were calculated. Changes in discharge were characterized as rapidly decreasing: $\geq-10$, slowly decreasing: $<-10$ to $>-1$, no change: \pm 1 , slowly increasing: $>1$ to $<10$, and rapidly increasing: $\geq 10 \%$. For water temperatures, six temperature ranges were utilized: $<10,10$ to $<$ $12.2,12.2$ to $<15.0,15.0$ to $<17.2,17.2$ to $<20.0$, and $\geq 20.0^{\circ} \mathrm{C}$. The analysis was based on a null hypothesis that the percentage of emigrants captured within an environmental range would not differ from the percentage of the emigration season within that environmental range. For example, if water temperatures of $\geq 20.0^{\circ} \mathrm{C}$ were encountered during $5 \%$ of the emigration season, then one would expect $5 \%$ of the emigrants to have been passed the traps within this temperature range. The emigration season was defined as being between the day when the first and last emigrant was observed.

Associations between canal diversion rate and trapping efficiency, river discharge and trapping efficiency, and water temperature and trapping efficiency were assessed using regression analysis. The variable reflecting diversion rate, river discharge, and water temperature was the average of the mean of the day of and the day after the trap efficiency release was made. Mean canal diversion rate was calculated by dividing the daily canal flow by the daily river flow. Daily river flow was calculated by adding the RM 2.1 gauge reading and the daily canal flow.

\section{Resident Species and Lamprey}

Resident fish were enumerated by species and fork length was recorded to the nearest mm. Total length was recorded and developmental stage was classified for juvenile lamprey. Larvae were identified as being brown in color with no eyes or a mouth. Macrophothalmia were silvery in color and had developed eyes and a mouth. Lamprey larger than $200 \mathrm{~mm}$ with eyes and a mouth were considered adults.

Trap efficiency tests utilizing macrophothalmia were performed at the rotary screw trap. Fish were marked with a small caudal fin clip (1-2 $\mathrm{mm}$ ) and held in a perforated bucket (in river) for 24 to 48 hours. Mortalities were removed and counted prior to transport to the release site. 
The release site was located approximately a quarter mile upstream (RM 1.5) of the trap. All lamprey data was submitted to CTUIR's lamprey restoration project (\# 94-026) for analyses and dissemination (Close, CTUIR, personal communication, 2002).

\section{RESULTS}

\section{Outmigration Monitoring}

\section{Fish Sampling and PIT-Tag Operations}

A total of 816 juvenile salmonids were sampled at the rotary-screw trap between 31 October 2001 and 9 March 2002 (Table 2). The trap operated continuously except during routine trap checks and during a high flow event in late February. Natural chinook salmon were observed throughout the sampling period; however, hatchery spring chinook salmon released in late February dominated the sample (68.4\%). Natural summer steelhead were not captured at the trap until January.

A total of 28,351 fish were sampled at the incline plane trap, which operated from 1 October through 30 October 2001, 7 March through 11 July 2002, and 20 September through 30 September 2002 (Table 2). Juvenile salmonids of hatchery origin dominated the sample $(63.8 \%)$, followed by coho salmon of unknown origin $(25.6 \%)$ and natural emigrants $(10.6 \%)$. No juvenile salmonids were captured at the incline plane trap during the month of September. Species composition through time of hatchery and natural emigrants is presented in Figures 4, 5, 6, and 7. A total of four adult summer steelhead ( 3 natural and 1 hatchery) and one unmarked fall chinook salmon were captured at the incline plane trap in 2002.

A combined total of 5,043 hours were sampled during the monitoring period for a daily average of 23.2 hours at the rotary-screw trap and 12.9 hours at the incline plane trap. Fish were bypassed $46.3 \%$ of the time at the incline plane trap. Sampling was not conducted between midJuly and late-September due low river flows and high water temperatures.

8,529 hatchery salmonids were tagged and released in the upper Umatilla River in 2002. In addition, 230 natural salmonids were tagged upriver by CTUIR. Of these, $13.7 \%$ of hatchery $(1,167)$ and $2.6 \%$ of natural (6) fish were interrogated at West Extension Canal (Table 3). Most fish (95.7\%) were passively interrogated through the $134 \mathrm{kHz}$ remote detection system. The remaining $4.3 \%$ were actively interrogated through hand sampling. In addition, two spring chinook salmon were interrogated in February through hand sampling at the rotary screw trap.

Hatchery species detected in the lower Umatilla River included yearling spring and fall chinook salmon, subyearling fall chinook salmon, coho salmon, and summer steelhead (Table 3). The interrogation system at West Extension Canal was not in operation until March, therefore detections of spring chinook salmon released in February were minimal. A significant difference in detection was not evident between over-wintered and standard acclimated spring chinook salmon. Fish reared in Michigan ponds exhibited slightly better detection rates than fish reared in Oregon ponds. Percent detection of Willard National Fish Hatchery spring chinook salmon released in March was 1 1/2 - 2 times less than that of fish from the Umatilla Fish Hatchery. Release timing appeared to be an important factor in relative detection of yearling fall chinook 
salmon. Fish released in March were detected nearly 3 times more than April released fish. Percent detection of subyearling fall chinook salmon acclimated at RM 73.5 was significantly lower than subyearlings direct-released at RM 48. Tagged coho salmon released in April were detected 2.5 times more than fish released in March, regardless of hatchery origin. Little difference in detection was evident between fish reared at Cascade and Herman Creek Fish Hatchery. Significant differences in detection were seen among of summer steelhead release groups. Extended-reared summer steelhead were detected less than standard-reared summer steelhead. In addition, detection of summer steelhead increased with decreased river mile of release.

One hundred seventy two juvenile fish were detected during the 2002 migration season at the east-bank fish ladder of Three Mile Falls Dam. Detections included hatchery production, ladder efficiency, and West Extension Canal trap efficiency fish. Six percent of all tagged hatchery production fish were interrogated with the temporary detection system. Seventy-eight adult salmonids were detected between October and December 2001. Of the adult returns, 16 were fall chinook salmon, 59 were coho salmon, and 3 were summer steelhead. All fish, with the exception of the summer steelhead were tagged as juveniles at John Day Dam and released at the Dalles Dam in May and June of 2000. Two of the summer steelhead were tagged at the Umatilla Fish Hatchery and released into the Umatilla River in April of 2000. The third was a natural fish tagged in the upper Umatilla River in April of 2000 as well. Detection efficiency for juvenile salmonids at the adult fish ladder ranged between 0.0 and $8.0 \%$ (Table 4 ).

\section{Fish Condition and Health}

Scale loss was minimal in 2002. Only $1.0 \%$ of the 12,573 fish examined were descaled (Table 5). Coho salmon of unknown origin had the highest descaling rate (1.4\%), followed by natural $(0.9 \%)$ and hatchery emigrants $(0.6 \%)$. Total weekly descaling rates were positively correlated to water temperature $(P=0.0339)$ and negatively correlated to secchi depth $(P=$ $0.0040)$. No relationship existed between descaling rates and river discharge.

Bird marks (2.8\%), body injuries (2.0\%), and parasites $(2.0 \%)$ were generally low in 2002 (Table 6). Bird marks were most prevalent on coho salmon of unknown origin $(3.4 \%)$, followed by hatchery $(3.1 \%)$ and natural emigrants $(1.3 \%)$. Juvenile salmonids of hatchery origin exhibited the highest incidence of body injuries (6.6\%) compared to unknown coho salmon $(2.1 \%)$ and natural emigrants $(1.2 \%)$. Parasites were observed on $11.8 \%$ of the natural emigrants, while less than $1 \%$ was observed on hatchery fish and coho salmon of unknown origin. Correlation analysis indicated that the weekly rate of bird marks $(P=0.0002)$, body injuries $(P=.0034)$, and parasites $(P=0.0001)$ were positively related to river discharge. Analysis also indicated a negative relationship with secchi depth $(P=0.0012, P=0.0012$, and $P$ $=0.0042$; respectively). No relationship existed between fish condition variables and water temperature.

Correlation analysis indicated that no relationship was evident between the smolt status of hatchery emigrants and fish size or period of peak migration. However, small sample sizes reduced the confidence in the results of the analysis for most hatchery groups. 
Total sampling mortality in 2002 was $2.1 \%$ (Table 7). Hatchery coho salmon exhibited the highest sampling mortality at $5.6 \%$. Subyearling chinook salmon was the only natural migrant with a sampling mortality rate over $1.0 \%$.

A total of 20 fish were submitted to ODFW Fish Pathology Lab for examination of fish health status. Results indicated that BKD was not present in natural emigrants; however, BKD was present in one coho salmon of unknown origin. A more detailed analysis, including ELISA test results for $\mathrm{BKD}$, cultured bacteria, and internal and external examination results can be found in Onjukka et al. (2003).

Monthly length-frequency distributions for all juvenile salmonids sampled are presented in Figures $8,9,10$, and 11 . Mean monthly fork lengths (Table 8 ) for hatchery yearling spring and fall chinook salmon decreased during the monitoring season, while hatchery coho and subyearling fall chinook salmon increased. Hatchery summer steelhead showed no significant change in size. Natural spring chinook salmon decreased in length between February and March, but increased to a maximum mean monthly fork length of $112.6 \mathrm{~mm}$ in May. Mean monthly fork length for natural subyearling chinook salmon ranged from 73.3 to $122.0 \mathrm{~mm}$. Natural summer steelhead were the largest natural emigrants, ranging in size from 68 to $320 \mathrm{~mm}$. Sample size was small for natural coho salmon, however it appears that fall emigrants are larger than those seen in the spring. Coho salmon of unknown origin increased in length between March and May, however a significant decrease was observed between May and June (144.5 to $95.4 \mathrm{~mm})$.

Mean growth rates for hatchery spring chinook salmon, subyearling fall chinook salmon, and summer steelhead were $0.12 \pm 0.01 \mathrm{~mm} / \mathrm{d}(\mathrm{SE}), 0.35 \pm 0.07 \mathrm{~mm} / \mathrm{d}$ (SE), and $0.24 \pm 0.03$ $\mathrm{mm} / \mathrm{d}(\mathrm{SE})$; respectively.

\section{Migration Parameters}

Production Fish: Peak movement of hatchery spring chinook salmon occurred between 3 and 34 days after the date of force release (Table 9; Figure 12). No peak date of detection was discernable for early released fish from either the Umatilla Fish Hatchery (February) or the Willard National Fish Hatchery (March). Migration parameters for the early Umatilla Fish Hatchery group were not determined due to the low number of detections. Fish reared at the Umatilla Fish Hatchery in Michigan raceways traveled $2 \frac{1}{2}-7$ times faster than all other groups of spring chinook salmon. Primary fish movement occurred during the day except in March, when the majority of fish moved at sunrise or sunset (Figure 13).

Primary movement of early released yearling fall chinook salmon occurred in April, 41 days after the date of force release (Table 9; Figure 12). No peak was discernable for the late released fish. Median travel speed of fall chinook salmon released in March was similar to April released fish. Diel movement of fall chinook salmon was similar to that of spring chinook salmon. The majority of fish moved during the day, except in March when primary fish movement occurred before sunrise or after sunset (Figure 13).

Peak emigration of subyearling fall chinook salmon occurred in late May. Detections peaked within 4 days following the date of force release (Table 9; Figure 14). Median travel speed was similar for all groups of fish. Duration of detection was shorter for direct-stream released fish 
compared to acclimated groups. Primary fish movement occurred between sunrise and sunset (Figure 15).

The majority of hatchery coho salmon emigrated between late April and early May regardless of release date or hatchery origin (Table 9; Figure 14). Median travel speed for March released coho was slower than all other species. Diel movement of coho salmon occurred primarily between sunrise and sunset (Figure 15).

Most summer steelhead appeared to move between May and early June regardless of release date. Peak movement was not discernable for 2 of 5 summer steelhead release groups but median passage dates were all within 2 weeks (Table 9; Figure 16). Median travel speed was similar for all groups with the exception of large-grade fish reared for an extended period at Umatilla Fish Hatchery. This group of fish traveled about $2 \frac{1}{2}$ times faster than all other groups. The majority of summer steelhead moved between sunrise and sunset (Figure 17).

Natural Fish: Migration parameters for natural fish were similar to previous years. Movement of spring chinook salmon peaked in early May, but median passage was 6 weeks earlier in late March (Table 10). Spring chinook salmon were first captured in January and last seen in late May. Peak and median passage for natural subyearling fall chinook was in late June. Subyearling migrants from October to December of 2001 were likely part of the 2001 migration year rather than 2002. Subyearling chinook salmon are typically moving through the lower river in June and July of the current migration year. Median and peak movement of coho salmon was in early June. Natural coho salmon were captured from October through July. Median passage of summer steelhead occurred in late April and peak passage one week later in May. Natural steelhead were first captured in January and last seen in June.

\section{Abundance and Survival}

\section{Migrant Abundance and Survival}

Production Fish: Significantly improved survival was observed for Umatilla Fish Hatchery spring chinook salmon (mean 98.1\%) over fish from the Willard National Fish Hatchery (27.3\%; Tables 11 and 12). In addition, mean survival of fish from oxygen-supplemented Michigan ponds (M2A-M2C; 112.6\%) was slightly higher than that of standard-reared fish (O5A and O5B; $85.1 \%$ ). Cold water reared (overwintered) spring chinook salmon (O4A and O4B) displayed little difference in survival (89.5\%) over standard-acclimated fish (O5A and O5B; 85.1\%). Due to high variability from annual trap efficiencies, confidence intervals were relatively wide and survival estimates high.

Spring chinook salmon reared at the Umatilla Fish Hatchery and released in March, exhibited improved migrant survival over both earlier (February) and later (April) released fish. Survival of the February release groups, however, was most likely underestimated as a result of detection facilities at the downstream dams not fully operating until March. Little difference in survival was noted between early (March) and late (April) release groups from the Willard National Fish Hatchery (27.3\% and 29.3\%, respectively). Overall migrant survival of hatchery spring chinook salmon was $63.2 \%( \pm 13.0 \%)$. 
Detection and survival of yearling fall chinook salmon was greater for March-released fish over April-released fish (Table 11). Overall, $60.4 \%$ of tagged yearling fall chinook salmon from these two groups survived to the lower Umatilla River $( \pm 16.7 \%)$.

Survival estimates for tagged subyearling fall chinook salmon reared at the Umatilla Fish Hatchery ranged from $36.7 \%-99.3 \%$ (Table 11). Fish direct-released at RM 48.5 exhibited significantly improved survival (93.7\%) over fish acclimated and released at RM 73.5 (40.2\%; Table 12). The overall migrant survival of tagged subyearling fall chinook salmon was $68.1 \%$ $( \pm 7.8 \%)$.

Survival estimates of hatchery summer steelhead indicated that large-grade steelhead tended to survive better over small-grade steelhead (mean 106.6\% vs.77.4\%; Tables 11 and 12). In addition, fish acclimated and released at Minthorn (RM 64.5) and Bonifer Springs (RM 7; Meacham RM 2) exhibited substantially reduced migrant survival over Pendleton released fish (RM 56). Standard reared fish displayed improved migrant survival over extended rearing scenarios (117.3\% vs. $66.7 \%)$. Regardless of size or rearing strategy applied, however, early released steelhead did not survive as well (64.9\%) as later-released fish $(133.7 \%)$. The overall survival of tagged summer steelhead reared at the Umatilla Fish Hatchery was $85.8 \%( \pm 15.4 \%)$.

Herman Creek Fish Hatchery coho salmon displayed considerably improved migrant survival (mean 55.9\%) over fish from the Cascade National Fish Hatchery (37.3\%). March (early) released fish exhibited similar survival rates to April (late) released fish, however binomial testing indicated significantly improved detections for later released fish (Table 12). The overall survival of tagged coho salmon was $30.1 \%( \pm 10.2)$.

Natural Fish: Survival of natural migrants was unable to be estimated due to the limited number of fish tagged. Migrant abundance of natural salmonids is presented in Table 13. Abundance estimates of chinook salmon includes both race (spring and fall chinook) and age classes $(0+$ and $1+)$ of fish. Abundance of chinook salmon peaked in March and was comprised primarily of age $1+$ fish $(81 \%)$. Total chinook abundance was estimated at 45,289 fish, of which $37,205(82 \%)$ were projected to be primarily spring chinook yearlings and 8,084 (18\%) subyearling spring and fall chinook.

Abundance of natural coho salmon peaked in May at 2,990 fish (67\%). Total abundance was estimated at 4,444 fish, and was comprised of both yearling and subyearling age classes (ascertained in the field as natural, apart from an unmarked designation).

Natural summer steelhead were most abundant in May as well, with $77 \%$ of the fish being sampled during the month. All age classes of steelhead were represented, with a total estimated abundance of 77,016 fish. Analysis of 1991-1996 age composition data from adult returns indicated approximately $88 \%$ of naturally produced steelhead smolts emigrated at age $2+$ (Chess et al. 2003). Therefore, of the 77,016 steelhead sampled in 2002, $605(0.8 \%)$ were estimated to be age $1+$ fish, $67,638(87.8 \%)$ age $2+$ fish, $8,194(10.6 \%)$ age $3+$ fish, and $579(0.8 \%)$ age $4+$ fish. 


\section{Trap Efficiencies}

Hatchery fish tagged for trap efficiency tests included 1,221 spring chinook salmon, 1,021 fall chinook salmon, 508 subyearling fall chinook salmon, and 891 summer steelhead. In addition, 1,206 coho salmon of unknown origin, 543 natural chinook salmon, and 271 natural summer steelhead were tagged (Table 14). Percent holding survival and tag retention were greater than $90 \%$ for all species with the exception of hatchery subyearling fall chinook salmon (tagged on 1 June 2002). The holding tank did not receive sufficient flow throughout the entire holding period, contributing to increased mortality (40\%; Table 14).

Significant differences were found among daily trap efficiency estimates for all fish groups (Table 15). Mean pooled estimates of trap efficiency data ranged between $21.1-36.9 \%$ for both natural and hatchery salmonids. Seventy eight to ninety seven percent of all test fish were detected within 5 days of release except for hatchery summer steelhead in which only $50.6 \%$ were detected. In addition, hatchery summer steelhead had the slowest overall mean travel time of all species. In general, trap efficiencies for most species increase with decreased river flow and increased canal diversion rates.

\section{Smolt-Yield-per-Spawner}

Smolt per spawner estimates of naturally produced juveniles for the 2002 outmigration year, revealed fall chinook salmon to have the lowest number of smolts per spawner (7.8) and summer steelhead to have the highest (29.4; Table 16). The number of smolts per spawner for naturally spawning spring chinook salmon was estimated at 25.1 .

\section{Transport Evaluation}

Transport evaluation tests revealed an increased detection of transported fish compared to non-transported fish (Table 17). Mean percent detection of non-transported subyearling fall chinook salmon released during low flow conditions $\left(17.2-95.5 \mathrm{f}^{3} / \mathrm{s}\right)$ and in-river temperatures of $18-22.5^{\circ} \mathrm{C}$, was $0.5 \%$. Transported subyearlings (treatment fish groups) on the other hand, displayed detection rates ranging from $1.8 \%$ to $17.5 \%$. Elevated holding temperatures and methodologies applied likely influenced the validity of the test. Binomial testing for significant differences between groups was not possible due to insufficient detections of non-transported fish.

\section{Environmental Conditions and Fish Passage Operations}

Mean weekly discharge in the lower river (RM 2.1) ranged from 2 to $2,182 \mathrm{cfs}$ during the 2002 Water Year (Figure 18). Daily mean discharge peaked at 4,989 cfs on 15 April 2002 and was recorded at only $1 \mathrm{cfs}$ on several days in July and August. Mean discharge exceeded 2,000 cfs for 8 days in 2002 and was below $50 \mathrm{cfs}$ for 38 days. Mean weekly water temperature ranged from 4.0 to $31.4^{\circ} \mathrm{C}$ (Figure 18). Water temperatures peaked on $13 \mathrm{July} 2002$ at $37.4^{\circ} \mathrm{C}$ and reached a low of $2.7^{\circ} \mathrm{C}$ on 29 January 2002. Daily mean water temperature exceeded $24.0^{\circ} \mathrm{C}$ for 55 days in 2002 , with 31 of those days at or above $28.0^{\circ} \mathrm{C}$. 
Mean weekly secchi depth ranged from 0.3 to 2.1 meters and is plotted against time in Figure 19. Secchi depth was negatively correlated with river discharge $(r=-0.818, P<0.001$, and $N=42$ ). As river discharge increased secchi depth (water clarity) decreased.

Springtime flow augmentation from McKay Reservoir began on 4 June 2002 and ceased on 7 July 2002 (Figure 20). McKay releases comprised 4.8 to $77.2 \%$ of the total river discharge for an average of $56.4 \%$. Releases were 5.1 to $19.3^{\circ} \mathrm{C}$ cooler than ambient stream temperatures (mean $14.2^{\circ} \mathrm{C}$; Figure 21 ). Sixty five percent of the hatchery subyearling fall chinook salmon and $93 \%$ of the natural subyearling fall chinook salmon were captured while flows were augmented.

Correlation analysis showed a positive, significant, relationship between river discharge and daily fish passage of all hatchery reared juvenile salmonids, except yearling fall chinook salmon and summer steelhead (Table 18). Natural spring chinook salmon, natural summer steelhead, and coho salmon of unknown origin also exhibited positive, significant, associations with river discharge and daily passage. No relationship was evident between river discharge and daily fish passage of natural coho or subyearling chinook salmon. Relationships between water temperature and daily fish passage were both positive and negative (Table 18). Hatchery spring chinook salmon and coho salmon of unknown origin had negative associations, while hatchery steelhead, natural subyearling chinook salmon, natural coho salmon, and natural summer steelhead all exhibited positive correlations. No relationship existed between water temperature and daily fish passage of hatchery coho salmon, subyearling fall chinook salmon, or natural spring chinook salmon.

Chi-squared goodness-of-fit test indicated that the emigration of all natural juvenile salmonids was not proportional to the percentage of the season within a given environmental range (Table 19). The movement of most natural emigrants occurred on a falling river limb and at water temperatures below $12.5^{\circ} \mathrm{C}$. However, the majority of natural subyearling chinook salmon $(63 \%)$ and coho salmon (39\%) passed the traps at water temperatures above $20^{\circ} \mathrm{C}$.

Linear regression analysis indicated that multiple environmental and operational variables influence the efficiency of the juvenile bypass facility at varying degrees for different groups of juvenile salmonids (Table 20). The highest regression coefficient was observed between natural chinook salmon trapping efficiency and all independent variables $\left(r^{2}=0.724, P=.007\right)$. There were no significant relationships between natural summer steelhead and all independent variables used in the regression analysis. The trapping efficiency of hatchery spring chinook salmon was positively correlated with canal diversion, explaining $55.7 \%$ of the variation in the efficiency of the juvenile bypass facility. Multiple-regression, using all variables, explained $61.0 \%$ of the variation in the efficiency of the bypass facility for hatchery spring chinook salmon $\left(r^{2}=0.610, P=0.004\right)$. The trapping efficiency of unknown coho salmon was also related to all variables with water temperature explaining $38.6 \%$ of the variation in the efficiency of the bypass facility. Multiple-regression indicated that all variables explained $42.9 \%$ of the variation of the bypass facility for unknown coho salmon $\left(r^{2}=0.429, P=0.044\right)$. 


\section{Resident Species and Lamprey}

A total of 7,646 resident species, including 110 Pacific lamprey, were collected during trapping operations (Tables 21 and Table 22). Chiselmouth (Acrocheilus alutaceus) and sucker species (Catostomus spp.) accounted for $80.7 \%$ of the resident species collection. The primary period of movement for resident fishes in 2002 was during early summer. A second period of movement was observed in late fall. A wide range in length for most species was observed throughout the trapping season.

Juvenile lamprey, macropothalmia and larvae, were captured at the rotary-screw trap between November 2001 and March 2002. The first fish was observed 7 November 2001 and the last was observed 4 March 2002. Two adult lamprey were captured at West Extension Canal during the month of June. Only one group of 67 juvenile lamprey was released for a trap efficiency estimate and no marked fish were recaptured. The length-frequency distribution for juvenile lamprey sampled in 2002 is presented in Figure 22. The average length for larvae and macrophothalmia was 154.8 and $147.0 \mathrm{~mm}$, respectively. A more detailed analysis of 2002 lamprey data will be performed by CTUIR (Close, CTUIR, personal communication, 2002).

\section{DISCUSSION}

\section{Outmigration Monitoring}

Little change was seen in migration parameters of hatchery or natural salmonids in 2002 compared with previous years. However, detection data of hatchery salmonids from $1999-2002$ has provided valuable information on emigration success of juvenile migrants and monitoring of migration trends (Ehlers et al 2001, Knapp et al 2002, and White et al 2003).

Juvenile detection data was unable to be analyzed for February released spring chinook salmon because downstream monitoring facilities were not operating until early March. Analysis of the performance of this group of fish compared to other strategies will be determined from coded-wire tag analysis of adult returns.

March released yearling fall chinook salmon were detected 3 times more at Three Mile Falls Dam than April released fish. However, cumulative unique detections at downstream dams were fairly similar between groups, suggesting that something other than release timing may be governing the migration and survival of yearling fall chinook in the Umatilla River. Fish released in March were subject to milder flow conditions ( $300 \mathrm{cfs}$ ), than fish released in April. In addition, April released fish were released during spring freshet, where flows reached a high of almost 5,000 cfs. Flows have not fluctuated this drastically since the 1997 migration year (Ehlers et al 2001, Knapp et al 1998b, 2000, 2002, and White et al 2003). Furthermore, trap efficiencies for yearling fall chinook salmon in 2002 were roughly 20\% in March but dropped to $1.5 \%$ during the April release. This suggests river discharge may be playing an important role in fish detection at West Extension Canal.

Second year evaluation following reduction of the subyearling fall chinook salmon program from 2.6 million to $600 \mathrm{~K}$, revealed emigration success of juvenile salmonids to be fairly similar to pre-reduction estimates. In-basin detections ranged between $22.0-35.0 \%$ in 1999 and 2000 
when 2.6 million fish were released. With the reduction in the program to $600 \mathrm{~K}$ in 2001 , detections increased slightly to $34.0-43.5 \%$. 2002 detections displayed a wider but similar range $(11.2-52.5 \%)$. Preliminary analysis of 2003 data suggests detections to be low for all groups $(<20 \%)$. This group of fish (subyearling fall chinook salmon) is exposed to extreme environmental conditions that fluctuate annually. Increased flows and reduced water temperatures are required in order to improve survival and emigration success. In years with higher water temperatures migrants may be more susceptible to disease (Becker \& Fujihara 1978) and/or increased levels of mortality. Increased flow augmentation during subyearling migration may increase survival (Conner et al 2003) and assist with data comparisons for purposes of program management.

Outmigration monitoring of acclimated coho salmon revealed results similar to 2001. As per previous years, coho salmon released in March did not move out until late April to early May, which may be a result of smolt development size (Thorpe 1988), environmental factors (McCormick et al. 1998), or both. In addition, detection data has revealed early released coho salmon to be detected significantly less than later released fish (White et al. 2003). Migration success does not appear to have been improved or in-river residence time reduced by acclimation of coho salmon. Preliminary analysis of 2003 data indicates similar trends.

Hatchery summer steelhead released lower in the river displayed improved emigration success and migrant survival over upper river releases. This was consistent with previous trends (Ehlers et al 2001, Knapp et al 2002, and White et al 2003). In addition, first year monitoring of large-grade steelhead released from the Pendleton Acclimation facility revealed an increased rate of detection and higher emigration success than fish from any other release group. Ward and Slaney (1993) found that releasing steelhead smolts in the lower reaches of rivers could maximize adult survival and minimize competition with wild steelhead. Releases of summer steelhead at the Pendleton acclimation facility should therefore be continued to determine if it is a better release location.

Scale loss in 2002 was the lowest observed in the last five years. Correlation analysis indicated a positive relationship between descaling rate and water temperature. This relationship is possibly due to scales being more easily dislodged, as juveniles become smolts, which is partially directed by water temperature (Bouck and Smith 1978; McCormick et al 1998). Hatchery emigrants, including coho salmon of unknown origin, continue to exhibit a higher descaling rate than natural emigrants. This is likely due to fish acclimation activities, including transportation, netting, tagging, and seining during force releases.

Bird marks and body injuries were down in 2002 compared to 2001; however, hatchery emigrants continued to exhibit higher rates compared to natural emigrants. In addition, hatchery summer steelhead continued to have the highest incidence of bird marks compared to any other species/origin type. Reasons for higher susceptibility of hatchery summer steelhead to avian predators and the potential for decreased emigration success has been discussed in past studies (Knapp et al 2002; Collis et al 2001; White et al 2003); however, current research activities do not address the number of emigrants being consumed by avian predators. The ability to quantify mortality due to predation by piscivorous birds would contribute to the better understanding of the effects of bird predation on the survival and condition of juvenile salmonids emigrating from the Umatilla River. Studies conducted in other systems, including the Columbia River, have indicated that mortality caused by foraging birds ranges from 2 to $22 \%$ (Ruggerone 1986). 
Results from such a study would provide co-mangers with direction for developing and implementing measures to reduce salmonid mortality caused by avian predators.

Parasites, predominately black spot, continue to be more prevalent on natural compared to hatchery emigrants. This is likely due to the difference in rearing conditions for the two groups and their length of residency in the Umatilla River. Naturally produced salmonids in the Umatilla River are exposed to a severely degraded system that has been placed on the Clean Water Act Section 303(d) list for impairing variables that include: temperature, $\mathrm{pH}$, aquatic weeds and algae, sedimentation, turbidity, habitat, ammonia, nitrate, bacteria, and flow modification (DEQ 2000). They are exposed to these sub-optimal conditions for 6 months to 3 years, depending upon the species. Data that links the incidence of black spot to habitat degradation in the Umatilla River is not available, however, a study by Steedman (1991) indicated that habitat degradation was associated with an increased incidence of black spot in 18 of 49 fish species, including salmonids, in 10 Canadian stream systems. In contrast, hatchery fish are being reared in an environment with controlled water quality parameters and reside in the Umatilla River for less than 6 months. This likely reduces the incidence of black spot in hatchery emigrants. It is not known weather black spot affects the emigration success of natural juvenile salmonids; however, severe infections can cause spinal deformities or secondary infections (Steedman 1991). The incidence of bacteria kidney disease continues to be high in some groups of hatchery produced spring chinook salmon smolts, however, laboratory tests by ODFW pathologists indicate the disease does not seem to be a problem of significance for natural smolts. General observations and a limited amount of natural fish health monitoring have indicated that the presence of diseased hatchery fish does not seem to be affecting the health of natural salmonids.

Monthly fork length distributions varied little for hatchery emigrants. In addition, all hatchery emigrants were larger than their natural counterparts. The observed decrease in mean fork length between the months of May and June for natural chinook salmon made it possible to delineate between yearling and subyearling emigrants; however, the ability to accurately distinguish between fall race and spring race populations as juveniles is not possible without genetic analysis (Connor et al 2001; Rasmussen et al 2003). The ability to discriminate between these populations would provide researchers and co-managers with added information on age structure and emigration timing of natural chinook salmon in the Umatilla River. These life history characteristics would provide valuable information that could be applied to refine population estimates, SAR's, and flow augmentation strategies.

The monthly fork length distributions for natural summer steelhead indicated the possibility for age-specific emigration timing. Large emigrants ( $\geq 300 \mathrm{~mm}$; Age $3+)$ are typically seen early in the migration-period, however, there is likely inter-annual variation due to the high variability in juvenile rearing conditions common to the Umatilla River basin. A more detailed analysis of scales collected from smolts in the future, and a review of historical data may shed more light on the life history characteristics of Umatilla River summer steelhead. A second theory incorporates the fall movement of juvenile summer steelhead from cooler, less productive tributaries and upper-river reaches into warmer, more productive lower-river reaches for winter rearing. Such movement has been observed at juvenile fish traps operated in the upper basin but very little juvenile monitoring has been conducted between RM 56.0 and RM 3.7 (Contor et al 1995 and 1996). An increased level of monitoring in the lower river would help explain life 
history characteristics of Umatilla River summer steelhead and identify areas being used for winter rearing to provide added direction in habitat restoration efforts.

Several years of fork length data and two years of PIT tag data has indicated a prolonged residency for hatchery coho salmon, in which they are actively feeding (increased monthly mean fork length during the monitoring period) and potentially competing with naturally rearing juvenile salmonids (Ehlers 2001; Knapp et al. 2000 and 2002; White et al. 2003). Ideally, hatchery smolts should only utilize the Umatilla River as an emigration corridor to the sea. An increased level of research and monitoring is needed to better evaluate the hatchery release strategies and post-release performance of juvenile coho salmon and their potential for interaction with natural rearing juvenile salmonids.

Numerous studies have identified fish size as a measure of smoltification for hatchery reared juvenile salmonids (Beckman et al 1999; Ewing et al 1980; Whalen et al 1999). In addition, previous assessments from hatchery smolts released in the Umatilla River have shown that fish released at a small size were not fully smolted, which potentially delayed their emigration timing (Knapp et al 1996, 1997, 1998, and 2000). However, analysis of smolt status for hatchery emigrants in 2002 did not indicate a relationship between the degree of smoltification and fork length; or degree of smoltification and period of peak emigration. This is possibly a result of small sample sizes and using visible brightness and the absence or presence of parr marks to determine smolt development. Ewing and Birks (1982) indicated that the disappearance of parr marks should be ruled out as criterion for smolt development since it is not cyclic and may be present during the lifetime of a fish. They also indicated that only gill $(\mathrm{Na}+\mathrm{K})$-ATPase activity showed a relationship between peaks in activity and migration or ocean entry in spring chinook salmon smolts.

\section{Abundance and Survival}

Production Fish: Migrant survival of tagged hatchery fish groups fluctuated considerably in 2002 compared to 2001 estimates $( \pm 6-50 \%$; TCW 5). Overall survival generally decreased for races of spring and fall chinook salmon and increased for coho salmon and summer steelhead. Regardless of fluctuations in survival, however, confidence intervals remained relatively similar. Annual fluctuations in estimates may be due to variations in hatchery rearing and release strategies, environmental conditions, or low and variable trap efficiencies, which hinder estimate accuracy. We are currently looking at means of refining estimate accuracy and reducing standard error. Refinements include, but are not limited to, statistical examination of fish tagging requirements, improvements in detection capabilities and review of alternate project methodologies (i.e. SURPH model).

Interestingly, survival of chinook salmon was similar among spring and fall races, as well as yearling and subyearling fish (60-68\%). Yearling fall chinook salmon survival remained relatively steady at $60 \%$, whereas survival of hatchery spring chinook salmon declined by $1 / 3$ in $2002(63 \%)$, compared with the previous year (94\%). Subyearling fall chinook salmon survival also exhibited a decline (68\%), in comparison to 2001 estimates $(112 \%)$.

Umatilla Fish Hatchery spring chinook salmon survived significantly better in 2002 compared to fish from the Willard National Fish Hatchery. This was similar to 2001 findings 
where Umatilla Fish Hatchery releases displayed improved survival over fish from the Little White Salmon and Carson National Fish Hatcheries. Over the past two years, spring chinook salmon reared at the Umatilla Fish Hatchery have experienced lower levels of disease (Onjukka et al. 2003), and improved survival over fish from any other hatchery. This improved survival could be due to the fact that Umatilla Fish Hatchery is fed by well water, whereas the other three hatcheries (Willard, Little White, and Carson) are fed by surface water. Additional hypothesis involve differences in the environment or medicated feeding regimes between production locations (Onjukka et al. 2003).

Hatchery spring chinook salmon reared in oxygen-supplemented Michigan ponds once again displayed slightly improved survival over standard-reared fish (OR-reared), however ANOVA testing with transformed data (OY 99-02) revealed no significant differences in survival between the two groups (Appendix Table 3). We found similar smolt-to-adult survival results, which were not significantly different between MI and OR-reared fish (Chess et al. 2003). Therefore contrary to expectations, oxygen supplemented rearing strategies may not have provided a survival advantage over standard-reared fish.

Similarly, 2002 cold-water reared (overwintered) spring chinook salmon displayed slightly improved survival over standard acclimated fish. However, ANOVA testing with transformed data (OY 99-02) revealed no significant difference in survival between the two groups (Appendix Table 3). The insignificant difference in juvenile survival may be a result of the smaller size-at-release of overwintered fish, which may have counteracted the benefits of the cold-water strategies. The intent of the cold-water rearing strategy was to extend the period of cold-water acclimation, thereby simulating conditions similar to those at Bonneville Fish Hatchery and potentially improving survival. Past studies have shown significantly improved survival of fish reared at Bonneville Fish Hatchery over those reared at Umatilla Fish Hatchery (BY91-BY93). The improved survival was attributed to Bonneville Fish Hatchery being fed by colder surface water whereas Umatilla Fish Hatchery being fed by warmer well water.

Spring chinook salmon released in February exhibited considerably reduced survival over March and April released fish. The poorer survival may be a result of the earlier release timing or due to detection facilities at downstream dams not fully operating until March. February released fish likely exited the Umatilla River prior to start-up of the West Extension Canal juvenile detection facility (07 March 03). Sampling at the rotary-screw trap revealed a wave of smolt migration in mid to late February, suggesting the fish had left the system shortly after release. Furthermore, the majority of fish detected were observed at the rotary-screw trap and the east bank adult fish ladder prior to the first week of March.

Second year evaluations following reduction of the subyearling fall chinook salmon program from 2.6 million to 600,000, revealed overall smolt survival to be similar to 1999 and 2000 (prereduction) estimates. Nevertheless, subyearlings direct released at RM 48.5 displayed significantly improved survival over fish acclimated and released at RM 73.5. The improved survival at RM 48.5 was likely a result of the lower release site and is consistent with reach survival findings where survival progressively increased with decreased river mile of release (White et al. 2003). The cold-water influence of McKay Creek Reservoir, which is used to augment lower river flow during smolt outmigration (Chess et al. 2003), may have also contributed to improved survival. McKay Creek, located at RM 52 provides roughly 1-27\% of the flow to the lower river during subyearling releases (late May). This additional flow may 
contribute to a cooling effect of waters immediately downstream, which may in turn impact survival.

The improved survival of large-grade compared to small-grade summer steelhead was consistent with previous findings (Knapp et al. 1998 and 2000; White et al. 2003). It was also consistent with to smolt-to-adult survival trends, which exhibited significantly improved survival of large-grade steelhead over smalls (Chess et al. 2003). The lower survival success of steelhead smalls may be indicative of their suspected residualism (White 2003; Chess et al. 2003) or potential to overwinter and migrate out as two-year-old fish (Knapp et al. 2000). Smolt monitoring has indicated smolts released as far back as 1998 have remained in the Umatilla for one and two years prior to emigrating. Three small-grade summer steelhead released for reach survival tests in 2001 for example, were detected at RM 3.7 in 2002. Similar results for steelhead smalls were observed in 2001 tagged production release groups (Stonecypher, pers. comm. 2002). Stonecypher et al. 2001 further reported only 3 out of 20 radio tagged small-grade steelhead migrated out of the basin subsequent to release. Local trout anglers have reported catching significant numbers of "resident trout" in the lower river (RM 32; Chess 2003). The delayed migration and increase in fresh water rearing may be a result of forcing hatchery steelhead into a 1 year old smolt, which is counter to a goal of mimicking natural life history patterns (Knapp et al. 2000 and 2002). Future releases should be closely monitored to assess the degree of suspected residualism and their potential impact on natural populations. Additional fish may need to be tagged or detection systems installed at upper river sites in order to document timing, location and/or migratory behavior of potential residuals.

The superior survival of lower released fish over upper river releases was once again evident in 2002. This was apparent for most species. Eight years of smolt migration monitoring has shown the Minthorn acclimation site (RM 64.5) to be a superior steelhead release location over that of Bonifer Springs (Meacham RM 2). Additionally, first year test releases from the Pendleton acclimation facility (RM 56) produced similar trends; improved survival of lower released fish.

Analysis of extended rearing strategies displayed results contrary to expectations. The original objective behind the extended rearing strategies was that it would augment smoltification and size at release, thereby improving survival and the steelheads desire to leave the system. However, far fewer extended reared fish were detected at Three Mile Falls Dam and lower Columbia River sites than standard reared fish. This indicated potentially one of two things: 1) reduced survival of extended reared fish, or 2) a tendency for extended reared fish to residualize. Evidence points towards the second option as the more likely possibility. Fish observed at the hatchery prior to release were noted to be precocially mature (Chess pers. comm. 2003), leading to speculation that they may have remained in the system subsequent to release and even attempted to spawn.

Second year tagging of coho salmon revealed improved survival over 2001 estimates. Contrary to the previous year, coho salmon reared at Herman Creek Fish Hatchery displayed improved survival over those reared at Cascade Fish Hatchery. This may be a result of fish from Herman Creek Fish Hatchery being affected by disease in 2001, which resulted in an increased in suspected mortality. 
Natural Fish: Natural smolt abundance generally improved in 2002 and was similar to 2000 estimates. Abundance of natural coho salmon nevertheless remained poor, with 53\% fewer migrants $(4,444)$ than estimated the previous year $(9,444)$. This reduced number of juvenile migrants is likely an artifact of $94 \%$ of hatchery released coho salmon not being marked (Rowan 2003), thus making it difficult to distinguish between hatchery and natural fish. An estimated 895,474 coho salmon of undetermined origin left the Umatilla River in 2002, which comprised $92.6 \%$ of the total estimated emigrants. Only $7 \%$ of emigrating coho were positively identified as hatchery released fish (clipped). Less than $1 \%$ was confirmed to be naturals.

The problem with not marking hatchery coho is that it makes it difficult to track natural abundance. Coho salmon have been historically released in the Umatilla River since 1966, however not consistently until 1987 (Rowan 2003). Since 1987 over 1 million coho have been released annually into the Umatilla, yet little monitoring has been conducted. Both the Master Plan and Subbasin Plan identify one of the fishery rehabilitation goals for the Umatilla River as reestablishing coho runs and sustainable harvest of salmon (CTUIR and ODFW 1989; and CTUIR and ODFW 2001). The Master Plan then goes on to describe the monitoring and evaluation (M\&E) goals for the restoration and enhancement of spring and fall chinook salmon and summer steelhead, but fails to mention coho salmon. Harvest plan guidelines, natural return expectations and disposition of coho salmon currently remain undefined (CTUIR and ODFW 1989; Saul et al. 2001). The lack of description of coho M\&E in the Master Plan occurred because coho releases are not part of the BPA funded production program. There is a need to conduct $\mathrm{M} \& \mathrm{E}$ on natural and artificial coho production due to the potential impacts of this program on other program goals.

Managers should consider the benefit coho salmon marking might have on addressing basin management objectives and natural production uncertainties. The 2002 coho migrants (yearling and subyearling) were produced from adult returns in 2000 (4,654; Zimmerman et al 2001) and 2001. With a combined return of nearly 23,000 coho (natural and hatchery) in 2001 (Zimmerman 2002), smolt production is expected to rise, with an increase in migrants in 2003.

Natural chinook salmon abundance improved in 2002 compared with the previous year. A total of 45,289 migrants were estimated in 2002, compared with 37,697 in 2001. This $20 \%$ increase in natural production appears to be derived from an increase in the number of emigrating yearling spring chinook salmon. Yearling chinook salmon abundance increased by almost 5 fold in 2002 (36,242 migrants vs.7,406 in 2001). The increase in yearling smolt abundance correlates with the higher number of adults, which were potentially available to spawn. An estimated 2,724 potential spawners were available in 2000 (Chess 2003), nearly a three fold increase over the last 10 years.

Although yearling chinook salmon abundance increased, subyearling abundance declined. An estimated $70 \%(21,244)$ fewer emigrants were evident in 2002 than observed in 2001 . The poorer migrant abundance may be attributed to reduced flows and elevated water temperatures during subyearling emigration. Sixty-three percent of subyearling migrants left the Umatilla in 2002 in water temperatures at or above $20^{\circ} \mathrm{C}$. In addition, Chess et al. (2003) suggested reduced subyearling production may be a result of high winter flow events and/or sediment transport and deposition from Wildhorse Creek, which likely affects egg and fry survival. 
Migrant abundance of natural summer steelhead rebounded in 2002 and was similar to 19982000 estimates. The drop in smolt abundance in 2001 may have been due to high water temperatures near the end of the migration period, which may have contributed to reduced survival.

2002 migrant abundance of natural salmonids was $10 \%$ of that of hatchery-produced fish. Of the total estimated abundance of emigrating salmonids in the Umatilla River basin, only $0.3 \%$ of coho salmon, $3.4 \%$ of chinook salmon and $5.8 \%$ of summer steelhead were estimated to be natural. With the exception of spring chinook salmon, abundance estimates for natural smolts fell well outside the expected range of natural production (Boyce 1986). 2002 steelhead abundance (77, 016 smolts) was substantially above Boyce's 1986 capacity predictions of 25,191 $-47,277$ smolts. Fall chinook production was significantly below the predicted range of 1 to 2 million smolts $(8,084$ smolts). Only abundance estimates for spring chinook salmon $(36,242)$ were within the range of predicted production (15,900-40,350). It should be noted, however, that predictions presented in Boyce's 1986 Comprehensive Report were compiled prior to completion of rehabilitation activities in the Umatilla River. Estimates assumed smolt production was limited chiefly by late summer rearing habitat for spring chinook salmon and summer steelhead, and overestimated the available spawning habitat for fall chinook salmon (Boyce 1986; Chess 2003). Production rates and natural spawning potential were additionally predicted using data from nearby basins (i.e. John Day, Deschutes, etc.). An updated version of natural production expectations should be constructed based on current knowledge and available data.

Smolt-Yield-per-Spawner: Over the past 6 years, the number of natural smolts per spawner for fish in the Umatilla River has ranged between 1-237, depending on the species (1997-2002 outmigration years). The narrowest range observed has been in natural summer steelhead, with smolt per spawner ratios that ranged between 21 and 53, with a mean of 32 . Although little comparable data is available for the same time period as that of the Umatilla, the Yakima River basin reported a mean of 97 smolts per spawner between 1997 and 2000, an average almost three times higher than that of the Umatilla River steelhead (Berg and Fast 2002; Chess et al. 2003).

Smolts per spawner estimates for spring chinook salmon over the last 6 years (OY 97-02) have ranged between 11 and 94, with a mean of 21. Chess et al. 2003 reported that this was considerably lower than predicted in nearby basins. The Yakima River and Tucannon River basins have averaged 103 and 85 smolts per spawner respectively, for the same timeframe (Chess et al. 2003; Berg and Fast 2002; Gallinat 2002). John Day estimates for the 2001 outmigration year were slightly more comparable at 59 smolts per spawner (Wilson et al 2001). Data suggests that in-basin productivity is substantially lower in the Umatilla River basin than that of surrounding Columbia River basins.

Natural fall chinook salmon have displayed the widest variation in the number of smolts per spawner over the last six years (1-237; a mean of 54). This fluctuation in estimates may be somewhat reflective of the fluctuation in the number of potential spawners, lower river flow, temperature, egg-to-fry survival, etc.

Transport Evaluation: Past transport evaluation studies conducted on the Umatilla River have provided mixed results in determining the effects of transportation on the survival of subyearling fall chinook salmon. Knapp et al (1998a and 1998b) reported that non-transported 
chinook salmon had a higher survival rate compared to transported fish. 2001 findings by White et al (2003) however, suggested opposite results; transported fish displayed improved survival over non-transported fish.

2002 transport evaluation tests suggest similar findings to 2001. Transported fish had a higher overall detection rate at mainstem and Columbia River dams than non-transported fish, suggesting survival of transported fish may be higher. However, the results are inconclusive. Binomial testing for statistical differences between groups was not possible due to insufficient detections of non-transported fish. Furthermore, numerous biases were associated with the experimental design and variable environmental conditions provided additional experimental constraints. For example, test fish consisted of hatchery-reared subyearling fall chinook salmon. True test fish would have consisted of natural subyearling fall chinook and been collected at Westland. In addition, fish were transferred to and held at West Extension Canal prior to being transferred to Westland and released. True control fish (non-transported) would not have been subject to any transportation or holding procedures. Furthermore, transported fish were subjected to lethal holding temperatures $\left(22-26^{\circ} \mathrm{C}\right)$, which resulted in the death and early release of nearly half of the fish. Additionally, due to restricted river flow, non-transported fish were released directly beneath the Stanfield Bridge instead of at Westland.

Additional testing should be conducted using pre-established parameters in order to obtain a clearer understanding of the potential benefits of transporting fish. Fish should consist of natural subyearling fall chinook salmon and be collected at Westland between late June and early July. Collection should commence once a pre-determined temperature and flow threshold have been met (i.e. $16^{\circ} \mathrm{C}$ and $150 \mathrm{cfs}$ ). Non-transported fish should be released immediately below Westland and transported fish trucked to the mouth and released. Neither group should be subjected to additional transportation or holding procedures. Furthermore, trap and haul operations should not be regarded as a long-term management strategy. Flow enhancement options should be pursued as they may be the only acceptable way to meet long-term fisheries goals in the Umatilla River (Boyce 1986).

\section{Environmental Conditions and Bypass Operations}

Environmental conditions during the 2002 emigration season were similar to past years. Early spring emigrants moving seaward between February and April continue to be exposed to more favorable environmental conditions compared to late spring and summer emigrants, moving between the months of May and June. Early spring emigrants are typically moving during periods of higher river discharge and lower water temperature. Mean monthly discharge typically decreases by $68 \%$ and river temperature increases by $5^{\circ} \mathrm{C}$ between April and May. In the Snake River, Conner et al (2003) indicated a possible survival advantage for hatchery subyearling fall chinook salmon released during periods of relatively high flow and cool water temperatures compared to those released during periods of relatively low flow and warm water temperatures. Higher river discharge may provide a survival advantage by increasing travel speed, thus reducing exposure time to predators. The corresponding decrease in water temperature may also reduce the potential for transmitting infectious diseases between individual fish. A potential survival disadvantage for early spring emigrants in the Umatilla River is the high turbidity levels typically observed during the emigration period. Servizi and Martens (1992) observed an increase in the number of juvenile coho salmon present near the water 
surface as turbidity increased. If this avoidance behavior is used by smolts in the Umatilla River it may increase their susceptibility to avian predation. In addition, high levels of suspended sediment potentially decrease egg-to-fry survival, reduce the feeding effectiveness of rearing juvenile salmonids, and limit the quantity and quality of spawning habitat present (Bisson and Bilby 1982; Servizi and Martens 1992).

Water temperature often exceeds the preferred temperature range $\left(9-15^{\circ} \mathrm{C}\right)$ and upper tolerance level $\left(25^{\circ} \mathrm{C}\right)$ for juvenile salmonids, and may affect the emigration success of salmonids in the Umatilla River (Brett 1952; Piper et al 1982). This is especially true for natural subyearling chinook salmon, with the majority of fish passing the lower river traps at temperatures $\geq 20^{\circ} \mathrm{C}(63 \%$ in 2002). High water temperature is also a concern for migrating adult spring chinook salmon and rearing juvenile spring chinook salmon, coho salmon, and summer steelhead. Adult spring chinook salmon must hold in the Umatilla River during seasonal low flow and maximum stream temperature periods. This is believed to be the primary cause of prespawn mortality and a potential limiting factor for the natural production of spring chinook salmon (Chess et al 2003; Contour and Kissner 2000). In addition, this is a critical time period for rearing juveniles. The potential negative effects caused by high stream temperatures on rearing juvenile salmonids include mortality, increased risk of infection, decreased foraging ability, decreased food supply, and limited growth (Bidgood and Berst 1969; Kaya 1978; and Nielson et al 1994). Past evaluations of the Umatilla River have identified summer low flows and high water temperatures as primary limiting factors to natural salmonid production throughout all life stages (Boyce 1985; Contor et al 1995; CTUIR 1994). An increase in the natural production potential of the Umatilla River is likely to occur only if the level of riparian habitat protection and restoration is increased in order to improve basin wide water quality. In addition, an increased level of monitoring and evaluation of migrating adults and rearing juveniles is needed to provide a clearer understanding of how these harsh environmental conditions are impacting natural production of spring chinook salmon. Research should also investigate the potential for local adaptation that may be responsible for the persistence of natural summer steelhead in water temperatures that frequently exceed their upper tolerance level during critical summer rearing periods.

Current and past reports have indicated that relationships between environmental variables and emigration timing of juvenile salmonids in the Umatilla River are species specific and variable from year to year (Ehlers et al 2001; Knapp et al 1996, 1998a, 1998b, 2000, and 2002; White et al 2003). The high variability in these relationships is likely due to seasonal variation in natural and augmented river flows, water temperature, and hatchery fish release sites, dates, and size. Pooling multiple years of data would likely provide a clearer understanding of the relationships between environmental variables and fish migration.

The efficiency of the juvenile bypass at West Extension Canal is influenced by water temperature, river flow, and canal diversion rate (Ehlers et al 2001; Knapp et al 1996, 1998a, 1998b, 2000, and 2002; White et al 2003). Relationships are species specific and variable from year to year. Combining multiple years of data would provide enough replicate releases of PITtagged smolts to generate a multi-variant smolt trapping relationship that could be used to refine current and future smolt abundance estimates. Such a model could also be developed by radio tracking juvenile salmonids over a wide range of environmental and operational conditions to identify route selection (adult ladder, juvenile bypass, or over the dam) under varying conditions. 
Experiments utilizing radio telemetry of juvenile salmonids would also provide quantifiable data to address concerns with potential passage delays as a result of current juvenile bypass operations and modifications. Current operating priorities (migrant trapping) and facility design require the bypass to be operated at $5 \mathrm{cfs}$; however, past studies indicated that fish moved through the bypass at a faster rate when flows were at $25 \mathrm{cfs}$ compared to $5 \mathrm{cfs}$ (Cameron and Knapp 1993; Hayes et al. 1992). Additional testing needs to be conducted to assure current operations are not negatively impacting migrating juvenile salmonids. This testing should be given high priority by basin co-mangers due to the importance of data collected at the juvenile bypass. The baseline data includes: species and stock composition of smolts, smolt production estimates, emigration timing, and in-basin survival. Monitoring of these parameters is vital to the overall evaluation of the rehabilitation of anadromous fish stocks in the Umatilla River Basin.

The effect of McKay Reservoir releases on the Umatilla River hydrograph and how it influences migration conditions, production, and survival of salmonids is not clearly understood. Close (1999) indicated that releases from McKay Reservoir reduced peak discharge and increased base-discharge. In particular, since the early 1900's summer discharge has more than tripled from RM 52.0 to RM 27.2; however, the river has been virtually de-watered from RM 27.2 to the confluence with the Columbia River. Also, fall base-discharge can be more than doubled when stored water is being released. Releases are primarily for irrigation purposes; however, protected blocks of water are released in the spring and fall to provide fish passage for adult and juvenile salmonids. General observations and preliminary analysis of water release data indicates that flow augmentation is providing water to the mouth for fish passage; however, significant reductions in water temperature are restricted to areas directly below McKay Reservoir (Ehlers et al. 2001; Knapp et al. 2000 and 2002; White et al. 2003). Current research being conducted by USBR will potentially provide more precise measurements and a clearer understanding of McKay Reservoir releases. This research may also provide some insight on the suspected late-summer rearing of juvenile salmonids in the lower Umatilla River; however, research also needs to address the spring and fall periods and potential impacts that releases may have on migrating and spawning salmonids. One area of concern is the potential migration bottleneck due to the extreme temperatures and flow differential at RM 52.0 during the spring migration period. Zimmerman and Duke (2001) reported the occurrence of adult spring chinook salmon at Westland Canal (RM 27.2) and Stanfield Ladder (RM 32.4) in late June. They indicated that the fish did not migrate upstream to summer holding areas, however, the observed number was low and currently not a problem of significant concern. Chess et al (2003) indicated that only $30-40 \%$ of the spring chinook salmon spawning escapement is accounted for by spawning ground surveys. This maybe a result of McKay Reservoir releases, a limited amount of summer holding habitat, pre-spawn mortality, harvest, or constraints on surveys due to environmental conditions. One additional uncertainty is if the cold water being released from McKay Reservoir is delaying the emigration of juvenile salmonids by reducing growth rates during the critical spring time period associated with successful smoltification (Conner and Burge 2003; Dickhoff et al 1997; Beckman and Dickhoff 1998). If the water releases are delaying the emigration of smolts from upriver areas, this potentially exposes them to higher water temperatures and lower discharge in the lower Umatilla River and mainstem Columbia River then would be experienced otherwise. This exposure to increased temperatures and decreased discharge may reduce their survival to ocean entry. An increased level of understanding with regards to flow exchange and augmentation and its effects on all stages of the salmonid life cycle is needed to effectively manage water in the Umatilla River. 


\section{Resident Species and Lamprey}

Year round trapping operations suggest that endemic species still dominate the resident fish population in the lower Umatilla River and several non-endemic species are present in smaller numbers. The wide range in size and time of capture of many different species of fishes suggests that multiple age classes of both endemic and non-endemic species are utilizing the lower Umatilla River throughout the year. The primary period of movement is in the early summer when water temperature increases, and again in the late fall when water temperature decreases.

The number of Pacific lamprey captured during the 2002 monitoring season dropped significantly from 2001. This reduction is possibly due to the limited operation of the rotaryscrew trap during high discharge events and a large number of emigrants being missed. An additional explanation may be that the drop in numbers is an indicator of a poor emigration year. Juveniles from the initial outplanting of 600 adults in 2000 are not expected to contribute to the total number of emigrants until 2004 (Close 2000; Close et al 2002).

Little is known in regards to current management strategies targeted on improving salmonid production and the effects they may have on resident fishes and Pacific lamprey. In particular, questions surrounding increases in spring and summer flows through exchange projects and McKay Reservoir water releases and how the distribution and diversity of resident species is being affected. If basin co-managers desire a better understanding of the entire aquatic community, specific research needs to be conducted to quantify resident fish populations and their role in the Umatilla River. 


\section{CONCLUSIONS}

\section{Migration Trends:}

Migration parameters of hatchery species have been similar the past 5 years (1998-2002).

$>$ Median passage of hatchery summer steelhead in 2002 was later than that of natural steelhead. In past years emigration of hatchery fish has mimicked that of natural fish.

$>$ Acclimated subyearling fall chinook salmon performed poorly in 2002 compared to direct-released fish. Four times fewer fish were detected than direct released fish.

$>$ Diel patterns of movement of hatchery salmonids were similar to previous years.

$>$ Migration parameters of coho salmon are currently poorly understood.

\section{Abundance and Survival:}

$>$ Migrant abundance of natural salmonids was estimated at only $10 \%$ of hatchery produced fish.

$>$ With the exception of spring chinook salmon, abundance estimates for natural smolts fell well outside the expected capacity of natural production.

$>$ Abundance estimates for coho salmon were extremely poor due to the high component of unmarked hatchery released fish.

$>$ Low smolt per spawner estimates suggested in-basin productivity to be substantially lower than that of nearby Columbia River tributaries.

$>$ Later released salmon continued to display improved migrant survival over early released fish.

$>$ Spring chinook salmon from the Umatilla Fish Hatchery continued to display significantly improved survival and lower levels of disease over fish from other hatcheries.

$>$ Migrant survival of MI-reared spring chinook salmon (oxygen-supplemented raceways) was not significantly different from that of OR-reared fish. This was consistent with smolt-to-adult survival trends.

$>$ Cold-water reared spring chinook salmon did not exhibit a survival advantage over standard acclimated fish.

$>$ Monitoring of February released spring chinook salmon was difficult due to the inoperation of downstream monitoring facilities.

$>$ Second year evaluations following reduction in the subyearling fall chinook salmon program revealed survival to be similar to pre-reduction estimates.

$>$ Large-grade summer steelhead continued to exhibit improved migrant survival over small-grade summer steelhead. This was consistent with smolt-to-adult survival trends.

$>$ The lower survival of summer steelhead smalls may be indicative of their suspected residualism or potential to overwinter and migrate out as two-year-old smolts.

$>$ Extended rearing scenarios for summer steelhead did not appear to provide a survival advantage over standard reared fish.

$>$ Transported fish had a higher overall detection rate at Three Mile Falls Dam and mainstem Columbia River dams, suggesting survival of transported fish may be higher.

$>$ Hatchery summer steelhead released at Bonifer Springs (RM 79) once again displayed reduced migrant survival over lower released fish. 


\section{Environmental Conditions:}

$>$ Emigrants moving between February and April are exposed to more favorable environmental conditions compared to those moving between May and June; however, no survival advantage was evident in 2002.

$>$ Low river discharge and high water temperature is a limiting factor for both hatchery and natural salmonids and may be reducing the success of emigrants moving between May and June.

$>$ Multiple environmental and operational variables appear to influence the migration timing of juvenile salmonids and efficiency of the juvenile bypass at West Extension Canal. Relationships are species specific and variable from year to year. Combining multiple years of data will likely help define the relationships.

$>$ McKay Reservoir releases continue to provide minimal amounts of flow for fish passage. Additional research is required to identify the potential affects of McKay Reservoir releases on all stages of the salmonid life cycle.

\section{Fish Sampling:}

Hatchery emigrants continue to be in poorer condition compared to natural emigrants, which may reduce their emigration success.

$>$ The ability to quantify mortality due to predation by piscivorous birds would contribute to the better understanding of the effects of bird predation on the survival and condition of juvenile salmonids emigrating from the Umatilla River.

$>$ Black spot disease continues to be highly prevalent in natural emigrants and is likely a result of poor water quality.

$>$ Hatchery emigrants continue to be larger than their natural counterparts.

$>$ The ability to accurately distinguish between fall race and spring race chinook salmon as juveniles would provide valuable information that could be applied to refine population estimates, SAR's, and flow augmentation strategies.

$>$ A more detailed age structure analysis for natural summer steelhead smolts is required to provide a clearer understanding of their life history characteristics.

$>$ An increased level of research and monitoring is needed to better evaluate the postrelease performance of juvenile coho salmon and their potential for interaction with natural rearing juvenile salmonids.

$>$ No apparent relationship between fish size and level of smoltification or period of peak emigration and level of smoltification is evident for hatchery reared juvenile salmonids using current methodology. Multiple physical and biochemical measures are likely required to accurately quantify the degree of smoltification and to ascertain relationships with fish size and period of peak migration. 


\section{RECOMMENDATIONS}

1. PIT tagging of natural salmonids in the upper Umatilla basin should be continued in order to ascertain origin of migrating smolts, estimate outmigrant survival, and monitor natural production. PIT tagging will aid in defining general trends and determining the effect of hatchery releases on natural species.

2. Releases of summer steelhead should be closely monitored to assess the degree of potential residualism and impact the releases may be having on natural populations. Additional fish may need to be tagged or detection systems installed at upper river sites to document timing, location and/or migratory behavior of potential residuals.

3. Managers should consider the benefit coho salmon marking might have on addressing management objectives and basin uncertainties. Marking would help differentiate between hatchery and naturally produced fish and assist with verification of migration parameters, abundance and survival estimates. Clipping would also help determine the effects of hatchery-produced fish on natural production.

4. New natural production goals for the Umatilla Basin should be developed to reflect current knowledge, habitat availability, limiting factors and basin capacity.

5. Installation of a permanent remote interrogation system at the east-bank fish ladder of Three Mile Falls Dam should be pursued and supported for detection of returning adults and juvenile migrants. This system would enhance estimates of juvenile migrants and provide valuable information on adult returns.

6. An increased level of understanding with regards to flow exchange and augmentation and its effects on all life stages of salmonids is required to effectively manage water in the Umatilla River. Additional research should be conducted to identify the potential affects of McKay Reservoir releases on natural and hatchery salmonids, particularly subyearling fall chinook salmon.

7. Preliminary findings suggest the early release of coho salmon should be eliminated. Second year evaluations of PIT tagged hatchery coho revealed survival of early released fish to be significantly lower than that of later releases. Initial review of 2003 data corroborates this finding.

8. Spring chinook salmon should continue to be reared at the Willard National Fish Hatchery rather than Little White Salmon National Fish Hatchery. If disease continues to be present at Little White Salmon National Fish Hatchery than an alternative rearing location should be found. 


\section{ACKNOWLEDGEMENTS}

Special recognition goes to Mr. Todd Anderson and Ms. Danette Ehlers for many hours of trap operation and field data collection. Additional recognition is extended to Ms. Suzanne Knapp who supervised project planning and field operations. The invaluable assistance of numerous field personnel, administrators, and agencies including individuals from the Bureau of Reclamation, West Extension Irrigation District, the fish passage facility's Operation \& Maintenance staff, ODFW Pathology staff in La Grande, Irrigon and Umatilla Hatchery personnel, the staff of the Umatilla Hatchery Monitoring and Evaluation project, staff of the Umatilla Hatchery Satellite Facilities Operation and Maintenance, and Bonneville Power Administration contract monitors Mr. Jay Marcotte and Mr. Jonathan McCloud was greatly appreciated.

\section{LITTERATURE CITED}

Becker, C.D. and M.P. Fujihara. 1978. The bacterial pathogen Flexibacter columnaris and epizootiology among Columbia River fish. A review and synthesis. American Fisheries Society, Monograph 2, Bethesda, Maryland.

Beckman, B.R., and W.W. Dickhoff. 1998. Plasticity of smolting in spring chinook salmon: relation to growth and insulin-like growth factor-I. Journal of Fish Biology 53:808-826.

Beckman, B.R., W.W. Dickhoff, W.S. Zaugg, C. Sharpe, S. Hirtzel, R. Schrock, D. Larsen, R.D. Ewing, A. Palmisano, C.B. Schreck, and C.V.W. Mahnken. 1999. Growth, smoltification, and smolt-to-adult return of spring chinook salmon from hatcheries on the Deschutes River, Oregon. Transactions of the American Fisheries Society 128:11251150 .

Berg, L. and D. Fast. 2002. Draft Yakima subbasin summary. Report prepared for the Northwest Power Planning Council, Portland, Oregon.

Bidgood, B.F., and A.H. Berst. 1969. Lethal temperatures for Great Lakes rainbow trout. Journal of the Fisheries Research Board of Canada 16:456-459.

Bisson, P.A., and R.E. Bilby. 1982. Avoidance of suspended sediment by juvenile coho salmon. North American Journal of Fisheries Management 4:371-374.

Bouck, G.R., and S.D. Smith. 1979. Mortality of experimentally descaled smolts of coho salmon (Oncorhynchus kisutch) in fresh and salt water. Transactions of the American Fisheries Society 108:67-69.

Boyce, R.R. 1986. A comprehensive plan for rehabilitation of anadromous fish stocks in the Umatilla river basin. Final report of Oregon Department of Fish and Wildlife to Bonneville Power Administration, Portland, Oregon.

Brett, J.R. 1952. Temperature tolerance in young Pacific salmon, genus Onchorhynchus. Journal of the Fisheries Research Board of Canada 9:265-323. 
Cameron, W.A. and S.M. Knapp. 1993. Report A. Pages 5-48 in S.M. Knapp, editor. Evaluation of juvenile fish bypass and adult passage facilities at water diversions in the Umatilla River: annual progress report 1992. Oregon Department of Fish and Wildlife and Confederated Tribes of the Umatilla Indian Reservation report to Bonneville Power Administration, Portland, Oregon.

Chess, D.W., W. Cameron, R.W. Stonecypher, Jr., and R. Carmichael. 2003. Draft. Comprehensive assessment of salmonid restoration and enhancement efforts in the Umatilla River Basin. Oregon Department of Fish and Wildlife report to Bonneville Power Administration, Portland, Oregon and the Independent Scientific Review Panel.

CBFWA Pittag Steering Committee 1999. PIT-tag marking station procedural manual. Version 1.0

Close, D.A. 1999. Restoration plan for Pacific lampreys (Lampetra tridentata) in the Umatilla River, Oregon. Confederated Tribes of the Umatilla Indian Reservation report to Bonneville Power Administration, Portland, Oregon.

Close, D.A. 2002. Pacific lamprey research and restoration project: annual report 2000. Prepared by the Confederated Tribes of the Umatilla Indian Reservation for the Bonneville Power Administration, Portland, Oregon.

Close, D.A., M.S. Fitzpatrick, and H.W. Li. 2002. The ecological and cultural importance of a species at risk of extinction, Pacific lamprey. Fisheries 27:19-25.

Collis, K., D.D. Roby, D.P. Craig, B.A. Ryan, and R.D. Ledgerwood. 2001. Colonial waterbird predation on juvenile salmonids tagged with passive integrated transponders in the Columbia River estuary: vulnerability of different salmonid species, stocks, and rearing types. Transactions of the American Fisheries Society 130:385-396.

Conner, W.P., H.L. Burge, J.R. Yearsley, and T.C. Bjornn. 2003. Influence of Flow and Temperature on Survival of Wild Subyearling Fall Chinook Salmon in the Snake River. North American Journal of Fisheries Management 23:362-375.

Connor, W.P., and H.L. Burge. 2003. Growth of wild subyearling fall chinook salmon in the Snake River. North American Journal of Fisheries Management 23:594-599.

Connor, W.P., S.G. Smith, T. Anderson, S.M. Bradbury, D.C. Burum, E.E. Hockersmith, M.L. Schuck, G.W. Mendel, and R.M. Bugert. 2003. In press. Post-release performance of hatchery yearling and subyearling fall chinook salmon released into the Snake River. M02-161 North American Journal of Fisheries Management.

Connor, W.P., A.R. Marshall, T.C. Bjornn, and H.L. Burge. 2001. Growth and long-range dispersal by wild subyearling spring and summer chinook salmon in the Snake River Basin. Transaction of the American Fisheries Society 130:1070-1076. 
Contor, C.R., E. Hoverson, and P. Kissner. 1995. Umatilla basin natural production monitoring and evaluation: annual progress report 1993-1994. Confederated Tribes of the Umatilla Indian Reservation report to Bonneville Power Administration, Portland, Oregon.

Contor, C.R., E. Hoverson, P. Kissner, and J. Volkman. 1996. Umatilla basin natural production monitoring and evaluation: annual progress report 1994-1995. Confederated Tribes of the Umatilla Indian Reservation report to Bonneville Power Administration, Portland, Oregon.

Contor, C.R., and P. Kissner. 2000. Umatilla basin natural production monitoring and evaluation: annual progress report 1997-1998. Confederated Tribes of the Umatilla Indian Reservation report to Bonneville Power Administration, Portland, Oregon.

Contor, C.R. 2003. - Umatilla basin natural production monitoring and evaluation project progress report 1999-2003. Fisheries program department of natural resources Confederated Tribes of the Umatilla Indian Reservation. Prepared for the U.S. Department of Energy Bonneville Power Administration, Division of Fish and Wildlife, Portland, Oregon.

CTUIR. 1994. Umatilla basin natural production monitoring and evaluation: annual progress report 1992-1993. Confederated Tribes of the Umatilla Indian Reservation report to Bonneville Power Administration, Portland, Oregon.

CTUIR (Confederated Tribes of the Umatilla Indian Reservation) and ODFW (Oregon Department of Fish and Wildlife). 1989. Umatilla River subbasin - salmon and steelhead plan. Prepared for the Northwest Power Planning Council for Columbia basin system planning.

Dauble, D.D., J. Skalski, A. Hoffman, and A. E. Giorgi. 1993. Evaluation and application of statistical methods for estimating smolt survival. Report to the Bonneville Power Administration, Portland, Oregon.

Dickhoff, W.W., B.R. Beckman, D.A. Larsen, C. Duan, and S. Moriyama. 1997. The role of growth in endocrine regulation of salmon smoltification. Fish Physiology and Biochemistry 17:231-236.

Efron, B. and R. Tibshirani. 1986. Bootstrap methods for standard errors, confidence intervals, and other measures of statistical accuracy. Statistical Science 1(1): 54-77.

Ehlers, D.L., S.M. Knapp, S.M. Jewett, and R.W. Carmichael. 2001. Evaluation of juvenile salmonid outmigration and survival in the lower Umatilla River basin: annual report 1999. Oregon Department of Fish and Wildlife report to Bonneville Power Administration, Portland, Oregon.

Ewing, R.D., H.J. Pribble, S.L. Johnson, C.A. Fustich, J. Diamond, and J.A. Lichatowich. 1980. Influence of size, growth rate, and photoperiod on cyclic changes in gill $(\mathrm{Na}+\mathrm{K})-$ ATPase activity in chinook salmon (Oncorhynchus tshawytscha). Canadian Journal of Fisheries and Aquatic Sciences 37:600-605. 
Ewing, R.D., and E.K. Birks. 1982. Criteria for parr-smolt transformation in juvenile chinook salmon (Oncorhynchus tshawytscha). Aquaculture 28:185-194.

Gallinat, M.P., L. Ross, and M. Varney. 2002. Tucannon River spring chinook salmon hatchery evaluation program: annual report 2001. Prepared for the U.S. Fish and Wildlife Service, Boise, Idaho.

Hayes, M.C., S.M. Knapp, and A.A. Nigro. 1992. Report B. Pages 53-104 in S.M. Knapp, editor. Evaluation of juvenile fish bypass and adult passage facilities at water diversions in the Umatilla River: annual progress report 1990-1991. Oregon Department of Fish and Wildlife and Confederated Tribes of the Umatilla Indian Reservation report to Bonneville Power Administration, Portland, Oregon.

Kaya, C.M. 1978. Thermal resistance of rainbow trout from a permanently heated stream, and of two hatchery strains. The Progressive Fish-Culturist 4:138-142.

Keefe, M.L., R.W. Carmichael, S.M. Focher W.J. Groberg, and M.C. Hayes. 1994. Fish research project - Oregon. Umatilla Hatchery monitoring and evaluation: 1993 annual report. Oregon Department of Fish and Wildlife report to Bonneville Power Administration, Portland, Oregon.

Knapp, S.M., D.L. Ehlers, J.C. Kern, W.A. Cameron, S.L. Shapleigh, and R.W. Carmichael. 1996. Evaluation of juvenile salmonid outmigration and survival in the lower Umatilla River: annual report 1995. Oregon Department of Fish and Wildlife report to Bonneville Power Administration, Portland, Oregon.

Knapp, S.M., J.C. Kern, W.A. Cameron, S.M. Snedaker, and R.W. Carmichael. 1998a. Evaluation of juvenile salmonid outmigration and survival in the lower Umatilla River basin. Annual progress report 1995-1996 prepared by the Oregon Department of Fish and Wildlife for the Bonneville Power Administration, Portland, Oregon.

Knapp, S.M., W.A. Cameron, J.C. Kern, and R.W. Carmichael. 1998b. Evaluation of juvenile salmonid outmigration and survival in the lower Umatilla River basin. Annual progress report 1996-1997 prepared by the Oregon Department of Fish and Wildlife for the Bonneville Power Administration, Portland, Oregon.

Knapp, S.M., D.L. Ehlers, S.M. Focher, T.A. Jones, and J.C. Kern, and R.W. Carmichael. 2000. Evaluation of juvenile salmonid outmigration and survival in the lower Umatilla River basin. Annual progress report 1997-1998 prepared by the Oregon Department of Fish and Wildlife for the Bonneville Power Administration, Portland, Oregon.

Knapp, S.M., D.L. Ehlers, S.M. Jewett, and R.W. Carmichael. 2002. Evaluation of juvenile salmonid outmigration and survival in the lower Umatilla River basin. Annual progress report 2000-2001 prepared by the Oregon Department of Fish and Wildlife for the Bonneville Power Administration, Portland, Oregon. 
Maynard, D.J., T.A. Flagg and C.V.W. Mahnken. 1995. A review of seminatural culture strategies for enhancing the postrelease survival of anadromous salmonids. American Fisheries Society Symposium 15:307-314.

McCormick, S.D., L.P. Hansen, T.P. Quinn, and R.L. Saunders. 1998. Movement, migration, and smolting of Atlantic salmon (Salmo salar). Canadian Journal of Fisheries and Aquatic Sciences 55:77-92.

Nielsen, J.L., T.E. Lisle, and V. Ozaki. 1994. Thermally stratified pools and their use by steelhead in northern California streams. Transactions of the American Fisheries Society 123:613-626.

Onjukka, S.T., G.M. O’Connor, B.M. Farman, and B. Myers. 2003. In press. Umatilla Hatchery monitoring and evaluation: Report B Fish health monitoring and evaluation. Annual reports 2001-2002. Oregon Department of Fish and Wildlife report to Bonneville Power Administration, Portland, Oregon.

Oregon Department of Environmental Quality in partnership with the Umatilla Basin Watershed Council and the Confederated Tribes of the Umatilla Indian Reservation. 2000. Draft. Umatilla River basin total daily maximum load and water quality management plan.

Piper, R.G., I.B. McElwain, L.E. Orme, J.P. McCaren, L.G. Fowler, and J.R. Leonard. 1982. Broodstock, spawning, and egg handling. Pages 134-135 in Fish Hatchery Management. United States Department of the Interior Fish and Wildlife Service, Washington, D.C.

Rasmussen, C., C.O. Ostberg, D.R. Clifton, J.L. Holloway, and R.J. Rodriguez. 2003. Identification of a genetic marker that discriminates ocean-type and stream-type chinook salmon in the Columbia River Basin. Transactions of the American Fisheries Society 132:131-142.

Ruggerone, G.T. 1986. Consumption of migrating juvenile salmonids by gulls foraging below a Columbia River dam. Transactions of the American Fisheries Society 115:736-742.

Rowan, G. 2003. Umatilla hatchery satellite facilities operation and maintenance: 2002 annual report. Prepared by the Confederated Tribes of the Umatilla Indian Reserve for Bonneville Power Administration.

SAS Institute, Inc. 1990. SAS language: reference, version 6.12. Cary, North Carolina.

Saul, D., C. Rabe, A. Davidson, and D. Rollins. 2001. Umatilla Subbasin Summary - Draft. Prepared for the Northwest Power Planning Council for the Columbia Plateau Rolling Provincial Review, August 2001.

Servizi, J.A., and D.W. Martens. 1992. Sublethal responses of coho salmon (Oncorhynchus kisutch) to suspended sediments. Canadian Journal of Fisheries and Aquatic Sciences 49:1389-1395.

Sokal, R. and F.J. Rohlf. 2001. Biometry, 3rd Edition. W.H. Freeman and Company, New York. 
Steedman, R.J. 1991. Occurrence and environmental correlates of black spot disease in stream fishes near Toronto, Ontario. Transactions of the American Fisheries Society 4:494-499.

Stonecypher, R.W., Jr., W.A. Cameron, M.C. Hayes, and R.W. Carmichael. 2001. Umatilla hatchery monitoring and evaluation. 1999 annual report to the Bonneville power Administration, Portland, Oregon.

Stonecypher, R.W. 2002. Personnal Communication.

Taylor, G. H. 1993. Normal annual precipitation, State of Oregon. Period 1961-1990. Map. Oregon climate Service, Oregon State University, Corvallis Oregon.

Thedinga, J.F., M.L. Murphy, S.W. Johnson, J.M. Lorenz, and K.V. Koski. 1994. Determination of smolt yield with rotary-screw traps in the Situk River, Alaska, to predict effects of glacial flooding. North American Journal of Fisheries Management 14:837-851.

Thorpe, J.E. 1988. Salmon migration. Sci. Prog. Oxford, 72:345-370

U.S. Geological Survey (USGS). 1989. Hydrological unit map, State of Oregon. U.S. Geological Survey, Reston, Virgina.

Ward, B.R., and P.A. Slaney. 1993. Returns of Pen-Reared Steelhead from Riverine, Estuarine, and Marine Releases. Transactions of the American Fisheries Society Vol. 119, No. 3, pp. 492-499.

Whalen, K.G., D.L. Parrish, and S.D. McCormick. 1999. Migration timing of Atlantic salmon smolts relative to environmental and physiological factors. Transactions of the American Fisheries Society 128:289-301.

White, T.C., S.M. Jewett, J.T. Hanson, and R.W. Carmichael. 2003. Evaluation of Juvenile salmonid outmigration and survival in the lower Umatilla River basin: Annual progress report 2000-2001 prepared by the Oregon Department of Fish and Wildlife for the Bonneville Power Administration, Portland, Oregon.

Wedemeyer, G.A., R.L. Saunders, and W.C. Clarke. 1980. Environmental factors affecting smoltification and early marine survival of anadromous salmonids. United States National Marine Fisheries Service Marine Fisheries Review 42:1-14.

Zimmerman, B. and B. Duke. 2001. Umatilla River Fish Passage Operations Program, Annual Progress Report, October 2000-September 2001. Prepared for Bonneville Power Administration by Confederated Tribes of the Umatilla Indian Reserve and the Oregon Department of Fish and Wildlife.

Zimmerman, B. 2002. Umatilla River Fish Passage Operations Program, Monthly Report, Historical Data, November 2002. 
Table 1. Summary of hatchery, rearing, acclimation and release strategies, Umatilla River 2002.

\begin{tabular}{|c|c|c|c|c|c|}
\hline $\begin{array}{l}\text { Hatchery, } \\
\text { raceway }\end{array}$ & $\begin{array}{l}\text { Rearing } \\
\text { strategy }\end{array}$ & $\begin{array}{l}\text { Acclimation } \\
\text { site }^{a}\end{array}$ & $\begin{array}{l}\text { Acclimation } \\
\text { period }\end{array}$ & $\begin{array}{l}\text { Release } \\
\text { site }\end{array}$ & $\begin{array}{c}\text { Release } \\
\text { type/period }\end{array}$ \\
\hline \multicolumn{6}{|c|}{ Spring Chinook Salmon } \\
\hline \multicolumn{6}{|c|}{ Umatilla Fish Hatchery } \\
\hline O4A & Oregon & IC-1 & 16 weeks & RM 80 & Early (Mar) \\
\hline O4B & Oregon & IC-1 & 16 weeks & RM 80 & Early (Mar) \\
\hline O5A & Oregon & IC-4 & 6 weeks & RM 80 & Early (Mar) \\
\hline O5B & Oregon & IC-4 & 6 weeks & RM 80 & Early (Mar) \\
\hline M2A & Michigan & IC-3 & 6 weeks & RM 80 & Early (Mar) \\
\hline M2B & Michigan & IC-3 & 6 weeks & RM 80 & Early (Mar) \\
\hline M2C & Michigan & IC-3 & 6 weeks & RM 80 & Early (Mar) \\
\hline M1A & Michigan & IC-2 & 3 weeks & RM 80 & Winter (Feb) \\
\hline M1B & Michigan & IC-2 & 3 weeks & RM 80 & Winter (Feb) \\
\hline M1C & Michigan & IC-2 & 3 weeks & RM 80 & Winter (Feb) \\
\hline \multicolumn{6}{|c|}{ Willard National Fish Hatchery } \\
\hline $41-45$ & Standard & IC-2 & 4 weeks & RM 80 & Early (Mar) \\
\hline $47-50,21-22$ & Standard & IC-3, 4 & 4 weeks & RM 80 & Late (Apr) \\
\hline \multicolumn{6}{|c|}{ Yearling Fall Chinook Salmon } \\
\hline \multicolumn{6}{|c|}{ Bonneville Fish Hatchery } \\
\hline A7-A11 & Standard & TH-1,2 & 3 weeks & RM 73.5 & Early (Mar) \\
\hline A2-A6 & Standard & TH-1,2 & 3 weeks & RM 73.5 & Late (Apr) \\
\hline \multicolumn{6}{|c|}{ Subyearling Fall Chinook Salmon } \\
\hline Umatilla Fish & & & & & \\
\hline $01 \mathrm{~A}$ & Oregon & TH-1 & 2 weeks & RM 73.5 & Single (May) \\
\hline 01B & Oregon & TH-2 & 2 weeks & RM 73.5 & Single (May) \\
\hline $02 \mathrm{~A}$ & Oregon & NA & None $e^{b}$ & RM 48.5 & Direct (May) \\
\hline 02B & Oregon & NA & None $^{b}$ & RM 48.5 & Direct (May) \\
\hline
\end{tabular}


Table 1. Continued.

\begin{tabular}{|c|c|c|c|c|c|}
\hline $\begin{array}{l}\text { Hatchery, } \\
\text { raceway }\end{array}$ & $\begin{array}{l}\text { Rearing } \\
\text { Strategy }\end{array}$ & $\begin{array}{c}\text { Acclimation } \\
\text { site }^{a}\end{array}$ & $\begin{array}{c}\text { Acclimation } \\
\text { period }\end{array}$ & $\begin{array}{c}\text { Release } \\
\text { Site } \\
\end{array}$ & $\begin{array}{c}\text { Release } \\
\text { type/period }\end{array}$ \\
\hline \multicolumn{6}{|c|}{ Summer Steelhead } \\
\hline \multicolumn{6}{|c|}{ Umatilla Fish Hatchery } \\
\hline M8A & Standard $-\mathrm{Sm}^{c}$ & $\mathrm{MN}$ & 4 weeks & RM 64.5 & Late (Apr) \\
\hline AEX & Extended $-\mathrm{Sm}^{c}$ & $\mathrm{MN}$ & None $^{b}$ & RM 64.5 & Late (Apr) \\
\hline M8B & Standard $-\operatorname{Lg}^{c}$ & $\mathrm{PN}$ & 4 weeks & RM 56 & Late (Apr) \\
\hline BEX & Extended $-\mathrm{Lg}^{c}$ & PN & None $^{b}$ & RM 56 & Late (Apr) \\
\hline $\mathrm{M} 8 \mathrm{C}$ & Standard $-\mathrm{Lg}^{c}$ & $\mathrm{BS}$ & 4 weeks & $\mathrm{RM} 79^{d}$ & Early (Apr) \\
\hline \multicolumn{6}{|c|}{ Coho Salmon } \\
\hline \multicolumn{6}{|c|}{ Cascade Fish Hatchery } \\
\hline $1-4$ & Standard & PE1 & 4 weeks & RM 56 & Early (Mar) \\
\hline $21-30$ & Standard & PE32 & 3 weeks & RM 56 & Late (Apr) \\
\hline \multicolumn{6}{|c|}{ Herman Creek Fish Hatchery } \\
\hline L1-L2 & Standard & PE31 & 3 weeks & RM 56 & Early (Mar) \\
\hline
\end{tabular}

c Standard $-L g=$ standard reared, large-grade summer steelhead, Standard - Sm $=$ standard reared, small-grade summer steelhead, Extended - Lg = extended reared large grade summer steelhead, and Extended - Sm $=$ extended reared small-grade summer steelhead.

$d \quad$ River mile 2 of Meacham Creek, which flows into RM 79 of the Umatilla River. 
Table 2. Number of juvenile salmonids sampled and total passage index at RM 1.2 and RM 3.7, Umatilla River, October 2001 - September 2002.

Species $^{a} \quad$ Number sampled $\quad$ Total passage index

$R M 1.2(11 / 01 / 01-03 / 09 / 02)$

HCHS

HSTS

NCHS

$\mathrm{NCHO}$

$\mathrm{NCOH}$

NSTS

Total
558

1

213

17

7

20

816
577

1

219

17

7

20

841

RM $3.7(10 / 01 / 01$ - 09/30/02)

\begin{tabular}{lcc} 
HCHS & 7,334 & 21,348 \\
HCHF & 4,050 & 9,392 \\
HCHF0 & 5,046 & 5,263 \\
HCOH & 623 & 1,376 \\
HSTS & 1,028 & 2,648 \\
UCOH & 7,267 & 16,231 \\
NCHS & 949 & 1,467 \\
NCH0 & 1,313 & 1,317 \\
NCOH & 129 & 155 \\
NSTS & 612 & 1,187 \\
Total & 28,351 & 60,384 \\
\hline
\end{tabular}

a $H C H S=$ hatchery spring chinook salmon, $H C H F=$ hatchery yearling fall chinook salmon, HCHF0 = hatchery subyearling fall chinook salmon, $\mathrm{HCOH}=$ hatchery coho salmon, HSTS = hatchery summer steelhead, UCOH = coho salmon of unknown origin, NCHS = natural spring chinook salmon, NCHO = natural subyearling chinook salmon, $N C O H=$ natural coho salmon, NSTS = natural summer steelhead. 
Table 3. PIT-tagged hatchery and natural production fish interrogated at RM 1.2 and 3.7, Umatilla River, February - September 2002.

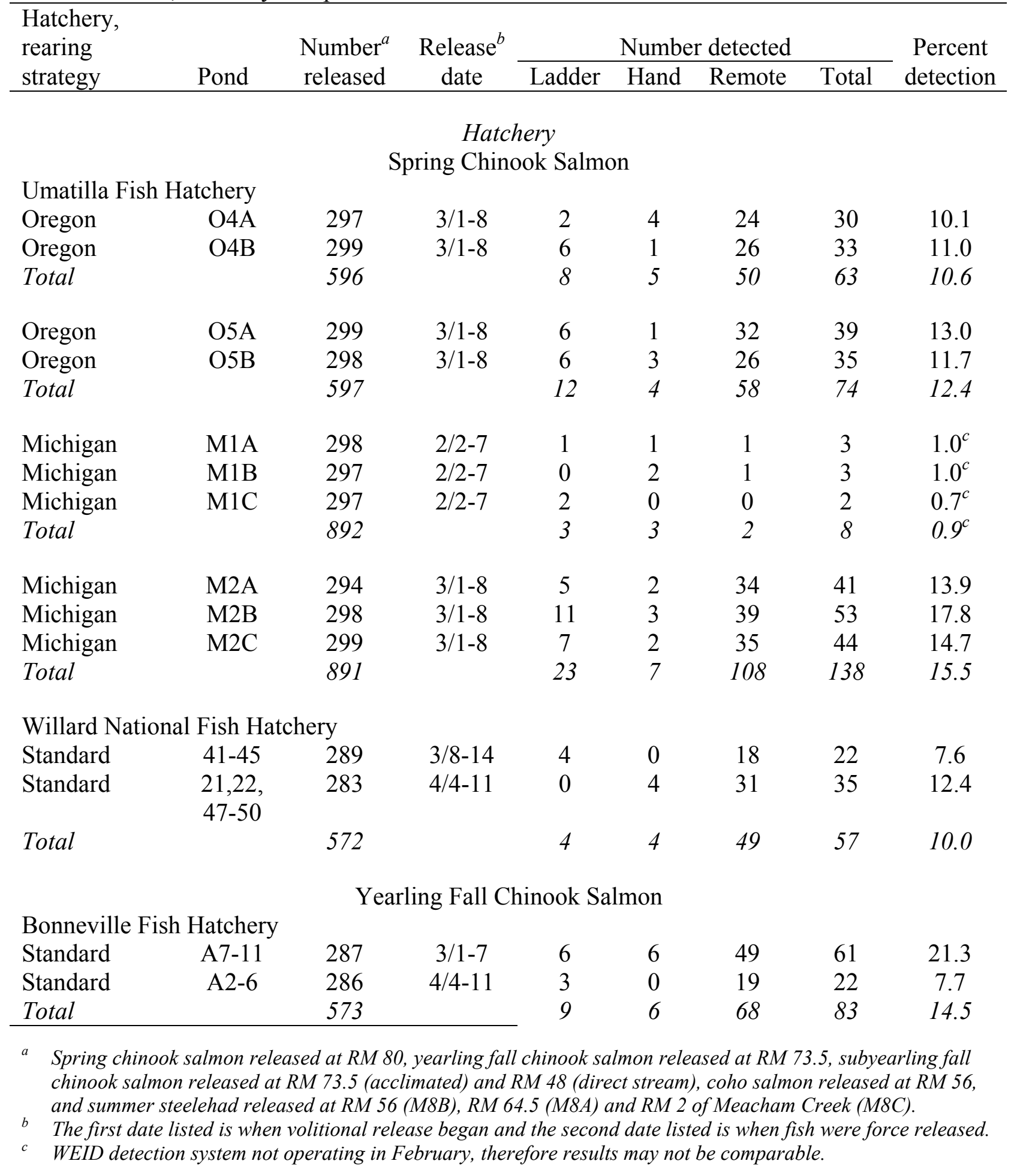


Table 3. Continued.

\begin{tabular}{|c|c|c|c|c|c|c|c|c|}
\hline \multirow{2}{*}{$\begin{array}{l}\text { Hatchery, } \\
\text { rearing }\end{array}$} & \multirow[b]{2}{*}{ Pond } & \multirow{2}{*}{$\begin{array}{l}\text { Number }^{a} \\
\text { released }\end{array}$} & \multirow{2}{*}{$\begin{array}{c}\text { Release }^{b} \\
\text { date }\end{array}$} & \multicolumn{4}{|c|}{ Number detected } & \multirow{2}{*}{$\begin{array}{l}\text { Percent } \\
\text { detection }\end{array}$} \\
\hline & & & & Ladder & Hand & Remote & Total & \\
\hline \multicolumn{9}{|c|}{ Subyearling Fall Chinook Salmon } \\
\hline \multicolumn{9}{|c|}{ Umatilla Fish Hatchery } \\
\hline Oregon & $01 \mathrm{~A}$ & 288 & $5 / 17-23$ & 1 & 2 & 39 & 42 & 14.6 \\
\hline Oregon & $01 \mathrm{~B}$ & 267 & $5 / 17-23$ & 1 & 4 & 25 & 30 & 11.2 \\
\hline \multicolumn{9}{|l|}{ Total } \\
\hline Oregon & 02A & 297 & $5 / 23$ & 1 & 0 & 155 & 156 & 52.5 \\
\hline Oregon & 02B & 299 & $5 / 23$ & 3 & 3 & 134 & 140 & 46.8 \\
\hline Total & & 1,151 & & 6 & 9 & 353 & 368 & 32.0 \\
\hline \multicolumn{9}{|c|}{ Coho Salmon } \\
\hline \multicolumn{9}{|c|}{ Cascade Fish Hatchery } \\
\hline Standard & $1-4$ & 300 & $3 / 2-7$ & 3 & 2 & 21 & 26 & 8.7 \\
\hline Standard & $21-30$ & 594 & $4 / 5-17$ & 0 & 4 & 113 & 117 & 19.7 \\
\hline Total & & 894 & & 3 & 6 & 134 & 143 & 16.0 \\
\hline \multicolumn{9}{|c|}{ Herman Creek Fish Hatchery } \\
\hline Standard & L1-L2 & 450 & $3 / 2-7$ & 2 & 3 & 31 & 36 & 8.0 \\
\hline \multicolumn{9}{|c|}{ Summer Steelhead } \\
\hline \multicolumn{9}{|c|}{ Umatilla Fish Hatchery } \\
\hline Large grade & $\mathrm{M} 8 \mathrm{C}$ & 268 & $4 / 2-9$ & 0 & 1 & 32 & 33 & 12.3 \\
\hline Large grade & M8B & 289 & $4 / 24-30$ & 2 & 1 & 62 & 65 & 22.5 \\
\hline Small grade & M8A & 593 & $4 / 24-30$ & 0 & 3 & 91 & 94 & 15.9 \\
\hline Small grade & $\mathrm{AEX}^{d}$ & 484 & $4 / 29$ & 2 & 1 & 39 & 42 & 8.7 \\
\hline Large grade & $\mathrm{BEX}^{d}$ & 279 & $4 / 30$ & 1 & 0 & 39 & 40 & 14.3 \\
\hline Total & & 1,913 & & 5 & 6 & 263 & 274 & 14.3 \\
\hline \multicolumn{9}{|c|}{$\begin{array}{c}\text { Natural } \\
\text { Spring Chinook Salmon }\end{array}$} \\
\hline Natural rearing & RM 80 & 217 & $9 / 27 / 01$ & 0 & 0 & 6 & 6 & 2.8 \\
\hline \multicolumn{9}{|c|}{ Coho Salmon } \\
\hline Natural rearing & RM 80 & 13 & $10 / 05 / 01$ & 0 & 0 & 0 & 0 & 0.0 \\
\hline
\end{tabular}

$d \quad$ Large and small grade summer steelhead reared at Umatilla Fish Hatchery for an extended period and then direct stream released at Minthorn (small grade) and Pendleton (large grade) acclimation facilities. 
Table 4. Detection efficiency and percent detection of juvenile salmonids interrogated at the east-bank adult fish ladder of Three Mile Falls Dam (RM 3.7), October 2001 - September 2002.

\begin{tabular}{lccc}
\hline Species & $\begin{array}{c}\text { Number } \\
\text { Released }\end{array}$ & $\begin{array}{c}\text { Number } \\
\text { detected }\end{array}$ & $\begin{array}{c}\text { Percent } \\
\text { detection }\end{array}$ \\
\hline \multirow{2}{*}{ Spring Chinook Salmon } & 25 & 0 & 0.0 \\
& 25 & 2 & 8.0 \\
& 25 & 0 & 0.0 \\
Total & 24 & 0 & 0.0 \\
Fall Chinook Salmon & 99 & 2 & 2.0 \\
& & & 4.3 \\
& 23 & 1 & 4.0 \\
Total & 25 & 1 & 0.0 \\
Subyearling Fall Chinook Salmon & 25 & 0 & 0.0 \\
& 24 & 0 & 2.1 \\
Total & 97 & 2 & 0.0 \\
Coho Salmon & 20 & 0 & 0.0 \\
Total & 20 & 0 & 0.0 \\
Summer Steelhead & 40 & 0 & 0.0 \\
Total & & & 16.0 \\
& 25 & 0 & 8.0 \\
& 25 & 4 & 0.0 \\
& 50 & 4 & \\
& & & \\
& 15 & 0.0 & \\
\end{tabular}


Table 5. Summary of scale loss for juvenile salmonids examined at RM 1.2 and 3.7, Umatilla River, October 2001 - September 2002.

Species $^{a} \quad$ Number examined $\%$ good condition $\%$ partially descaled $\%$ descaled

\section{Hatchery}

$\begin{array}{lcccc}\text { CHS } & 3,563 & 93.4 & 5.8 & 0.8 \\ \text { CHF } & 1,473 & 96.0 & 2.8 & 1.2 \\ \text { CHF0 } & 1,699 & 95.8 & 3.1 & 1.2 \\ \text { COH } & 296 & 92.6 & 5.7 & 1.7 \\ \text { STS } & 533 & 95.5 & 4.3 & 0.2\end{array}$

\section{Natural}

$\begin{array}{lcccc}\text { CHS } & 851 & 95.3 & 4.3 & 0.4 \\ \text { CH0 } & 822 & 92.1 & 6.2 & 1.7 \\ \text { COH } & 83 & 91.6 & 7.2 & 1.2 \\ \text { STS } & 587 & 97.4 & 1.9 & 0.7\end{array}$

\section{Unknown}

\begin{tabular}{lllll}
$\mathrm{COH}$ & 2,666 & 93.4 & 5.3 & 1.4 \\
Total & 12,573 & 94.3 & 4.7 & 1.0 \\
\hline
\end{tabular}

a $C H S=$ spring chinook salmon, $C H F=$ yearling fall chinook salmon, CHF0 = subyearling fall chinook salmon, $\mathrm{COH}=$ coho salmon, and STS = summer steelhead, $\mathrm{CHO}=$ subyearling chinook salmon . 
Table 6. Summary of fish condition for juvenile salmonids examined at RM 1.2 and 3.7, Umatilla River, October 2001 - September 2002.

Species Number examined \% bird marks \% body injuries $\%$ parasites

\section{Hatchery}

$\begin{array}{lcccc}\text { CHS } & 3,563 & 3.4 & 2.4 & 0.9 \\ \text { CHF } & 1,473 & 4.5 & 3.9 & 1.0 \\ \text { CHF0 } & 1,699 & 0.2 & 0.9 & 0.0 \\ \text { COH } & 296 & 3.4 & 2.4 & 0.0 \\ \text { STS } & 533 & 6.8 & 1.5 & 0.2\end{array}$

\section{Natural}

$\begin{array}{lcccc}\text { CHS } & 851 & 1.4 & 1.2 & 22.7 \\ \text { CH0 } & 822 & 0.4 & 1.2 & 4.6 \\ \text { COH } & 83 & 1.2 & 1.2 & 7.2 \\ \text { STS } & 587 & 2.4 & 1.4 & 6.8\end{array}$

Unknown

\begin{tabular}{lcccc}
$\mathrm{COH}$ & 2,666 & 3.4 & 2.1 & 0.2 \\
Total & 12,573 & 2.8 & 2.0 & 2.6 \\
\hline
\end{tabular}


Table 7. Mortality rates for juvenile salmonids sampled at RM 1.2 and RM 3.7, Umatilla River, October 2001 - September 2002.

\begin{tabular}{llccc}
\hline & & $\%$ unknown & $\%$ sampling & $\%$ total \\
Species & Number sampled & mortality & mortality & mortality \\
\hline
\end{tabular}

Hatchery

$\begin{array}{lcccc}\text { CHS } & 7,892 & 0.11 & 0.85 & 0.96 \\ \text { CHF } & 4,050 & 0.20 & 2.71 & 2.91 \\ \text { CHF0 } & 5,046 & 0.22 & 1.13 & 1.35 \\ \text { COH } & 623 & 0.00 & 5.62 & 5.62 \\ \text { STS } & 1,029 & 0.10 & 1.26 & 1.36\end{array}$

Natural

$\begin{array}{lcccc}\text { CHS } & 1,162 & 0.00 & 1.03 & 1.03 \\ \text { CH0 } & 1,330 & 0.15 & 3.38 & 3.53 \\ \text { COH } & 136 & 0.74 & 0.74 & 1.48 \\ \text { STS } & 632 & 0.00 & 0.95 & 0.95\end{array}$

Unknown

\begin{tabular}{lcccc}
$\mathrm{COH}$ & 7,267 & 0.11 & 3.73 & 3.84 \\
Total & 21,900 & 0.14 & 2.11 & 2.25 \\
\hline
\end{tabular}


Table 8. Fork length (mm) summary of juvenile salmonids examined at RM 1.2 and RM 3.7, Umatilla River, October 2001 - September 2002.

\begin{tabular}{|c|c|c|c|c|c|c|c|c|c|c|c|c|}
\hline \multirow[b]{2}{*}{ Species } & \multicolumn{12}{|c|}{ Month } \\
\hline & October & November & December & January & February & March & April & May & June & July & August & September \\
\hline
\end{tabular}

\section{Hatchery}

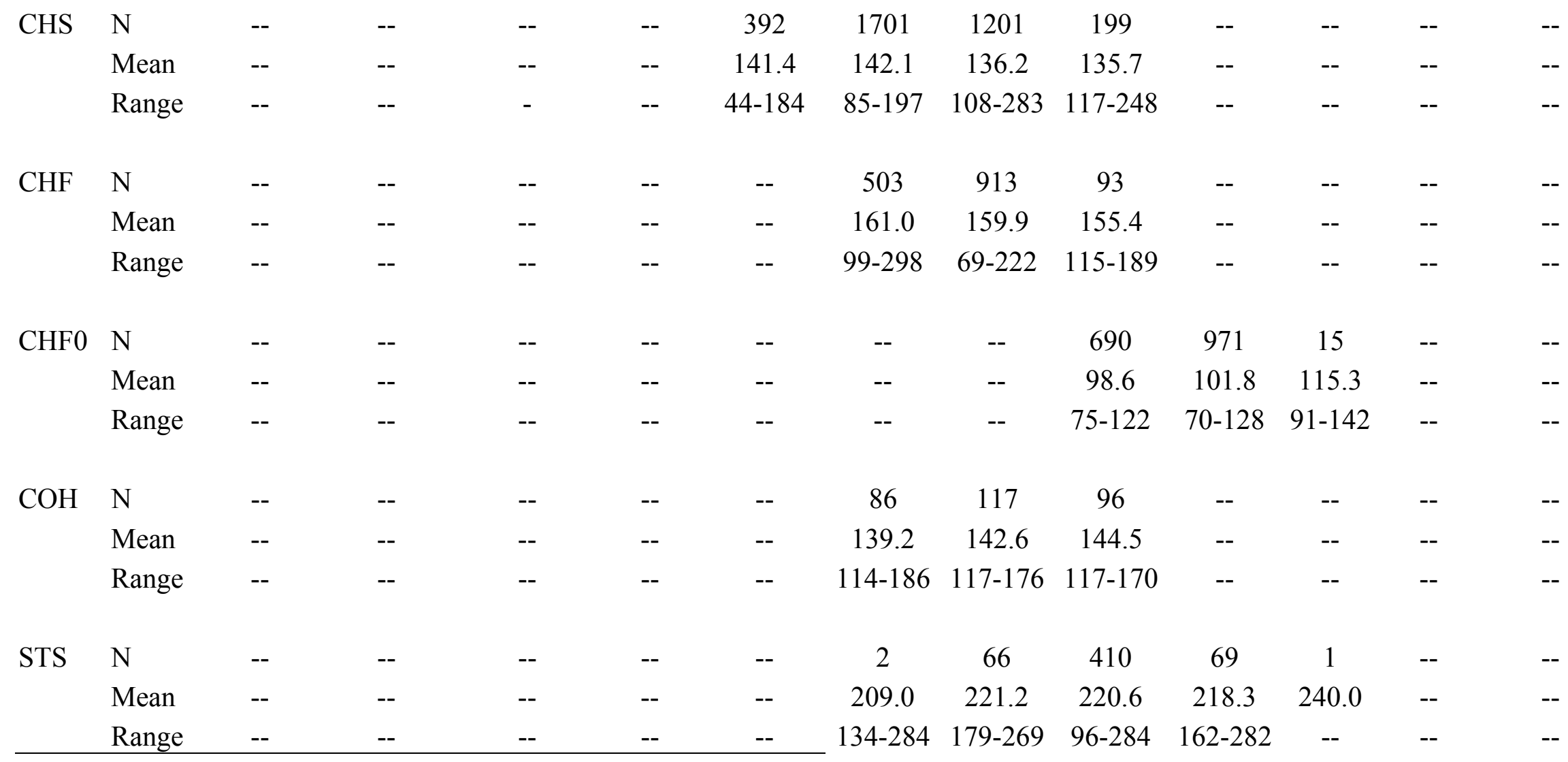


Table 8. Continued.

\begin{tabular}{|c|c|c|c|c|c|c|c|c|c|c|c|c|c|}
\hline \multirow{2}{*}{ Specie } & & \multicolumn{12}{|c|}{ Month } \\
\hline & & October & November & December & January & February & March & April & May & June & July & August & September \\
\hline \multicolumn{14}{|c|}{ Natural } \\
\hline \multirow[t]{3}{*}{ CHS } & $\mathrm{N}$ & -- & -- & -- & 28 & 61 & 443 & 243 & 86 & -- & -- & -- & -- \\
\hline & Mean & -- & -- & -- & 96.1 & 108.3 & 95.2 & 105.3 & 112.6 & -- & -- & -- & -- \\
\hline & Range & -- & -- & -- & $78-119$ & $79-156$ & $70-168$ & $79-148$ & $83-154$ & -- & -- & -- & -- \\
\hline \multirow[t]{3}{*}{$\mathrm{CH} 0$} & $\mathrm{~N}$ & 82 & 7 & 9 & -- & -- & -- & -- & -- & 582 & 141 & -- & -- \\
\hline & Mean & 122.0 & 117.0 & 115.7 & -- & -- & -- & -- & -- & 73.3 & 75.7 & -- & -- \\
\hline & Range & $90-154$ & $95-142$ & $91-125$ & -- & -- & -- & -- & -- & $46-115$ & $47-104$ & -- & -- \\
\hline \multirow[t]{3}{*}{$\mathrm{COH}$} & $\mathrm{N}$ & 2 & 3 & 4 & -- & -- & 1 & 7 & 10 & 55 & 2 & -- & -- \\
\hline & Mean & 107.5 & 92.7 & 104.0 & -- & -- & 86.0 & 73.0 & 71.2 & 81.6 & 83.5 & -- & -- \\
\hline & Range & $107-108$ & $90-95$ & $88-130$ & -- & -- & -- & $41-106$ & $41-135$ & $52-147$ & $67-100$ & -- & -- \\
\hline \multirow[t]{3}{*}{ STS } & $\mathrm{N}$ & -- & -- & -- & 2 & 10 & 106 & 158 & 238 & 58 & -- & -- & -- \\
\hline & Mean & -- & -- & -- & 131.0 & 149.4 & 156.4 & 173.6 & 164.8 & 165.6 & -- & -- & -- \\
\hline & Range & -- & -- & -- & $127-135$ & $106-195$ & $68-305$ & $75-320$ & $59-211$ & $145-201$ & -- & -- & -- \\
\hline \multicolumn{14}{|c|}{ Unknown } \\
\hline \multirow[t]{3}{*}{$\mathrm{COH}$} & $\mathrm{N}$ & -- & -- & -- & -- & -- & 540 & 999 & 1102 & 51 & 4 & -- & -- \\
\hline & Mean & -- & -- & -- & -- & -- & 137.0 & 143.6 & 144.5 & 95.4 & 114.8 & -- & -- \\
\hline & Range & -- & -- & -- & -- & -- & 99-189 & $106-284$ & 93-176 & 54-166 & $101-125$ & -- & -- \\
\hline
\end{tabular}


Table 9. Migration parameters of PIT-tagged hatchery salmonids monitored at RM 1.2 and RM 3.7, Umatilla River, October 2001 - September 2002.

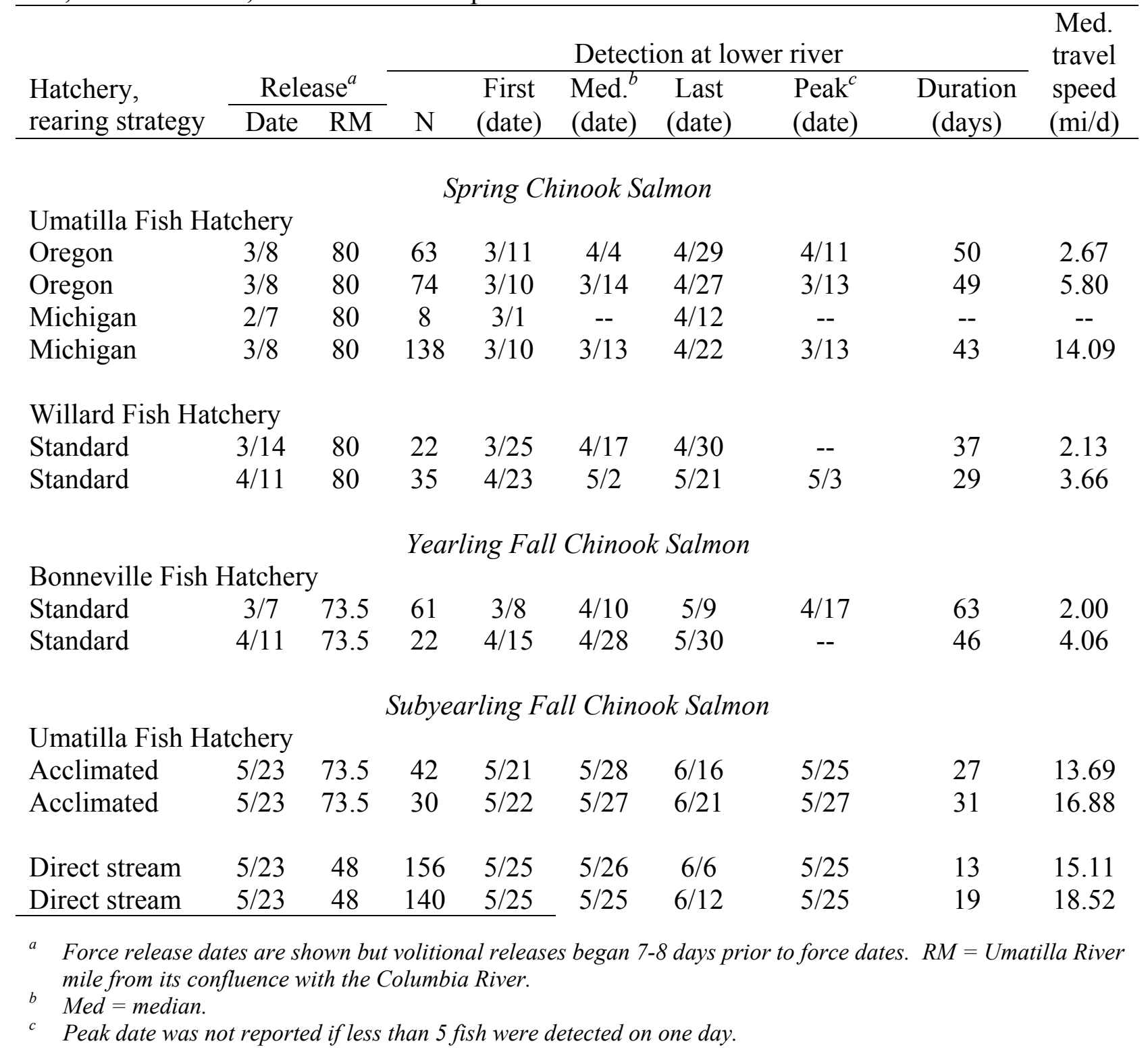


Table 9. Continued.

\begin{tabular}{|c|c|c|c|c|c|c|c|c|c|}
\hline \multirow{3}{*}{$\begin{array}{l}\text { Hatchery, } \\
\text { rearing strategy }\end{array}$} & & & \multicolumn{6}{|c|}{ Detection at lower river } & \multirow{3}{*}{$\begin{array}{l}\text { Med. } \\
\text { travel } \\
\text { speed } \\
(\mathrm{mi} / \mathrm{d})\end{array}$} \\
\hline & \multicolumn{2}{|c|}{ Release $^{a}$} & \multirow[b]{2}{*}{$\mathrm{N}$} & \multirow{2}{*}{$\begin{array}{l}\text { First } \\
\text { (date) }\end{array}$} & \multirow{2}{*}{$\begin{array}{l}\text { Med. }^{b} \\
\text { (date) }\end{array}$} & \multirow{2}{*}{$\begin{array}{l}\text { Last } \\
\text { (date) }\end{array}$} & \multirow{2}{*}{$\begin{array}{l}\text { Peak }^{c} \\
\text { (date) }\end{array}$} & \multirow{2}{*}{$\begin{array}{c}\text { Duration } \\
\text { (days) }\end{array}$} & \\
\hline & Date & RM & & & & & & & \\
\hline \multicolumn{10}{|c|}{ Coho Salmon } \\
\hline \multicolumn{10}{|c|}{ Cascade Hatchery } \\
\hline Standard & $3 / 7$ & 56 & 26 & $3 / 22$ & $4 / 18$ & $5 / 26$ & $3 / 25$ & 66 & 1.08 \\
\hline Standard & $4 / 17$ & 56 & 117 & $4 / 16$ & $5 / 3$ & $5 / 24$ & $5 / 3$ & 39 & 3.19 \\
\hline \multicolumn{10}{|c|}{ Herman Creek Hatchery } \\
\hline Standard & $3 / 7$ & 56 & 36 & $3 / 8$ & $4 / 18$ & $5 / 25$ & $3 / 25$ & 79 & 1.00 \\
\hline \multicolumn{10}{|c|}{ Summer Steelhead } \\
\hline \multicolumn{10}{|c|}{ Umatilla Fish Hatchery } \\
\hline Large grade & $4 / 9$ & 79 & 33 & $4 / 13$ & $5 / 6$ & $6 / 8$ & -- & 57 & 2.83 \\
\hline Large grade & $4 / 30$ & 56 & 65 & $5 / 1$ & $5 / 17$ & $6 / 2$ & $5 / 4$ & 33 & 2.97 \\
\hline Large grade ${ }^{d}$ & $4 / 30$ & 56 & 40 & $5 / 2$ & $5 / 7$ & $6 / 2$ & -- & 32 & 7.14 \\
\hline Small grade & $4 / 30$ & 64.5 & 94 & $5 / 2$ & $5 / 20$ & $6 / 5$ & $5 / 29$ & 35 & 2.99 \\
\hline Small grade ${ }^{d}$ & $4 / 29$ & 64.5 & 42 & $5 / 3$ & $5 / 21$ & $6 / 2$ & $5 / 22$ & 31 & 2.73 \\
\hline
\end{tabular}

d PIT tagged summer steelhead reared at Umatilla Fish Hatchery for an extended period and then direct stream released at Minthorn (small grade) and Pendleton (large grade) acclimation facilities. 
Table 10. Migration parameters of natural salmonids passing RM 1.2 and RM 3.7, Umatilla River, October 2001 - July 2002.

\begin{tabular}{|c|c|c|c|c|c|}
\hline $\begin{array}{l}\text { Number } \\
\text { passed }\end{array}$ & $\begin{array}{l}\text { First } \\
\text { (date) }\end{array}$ & $\begin{array}{c}\text { Median } \\
\text { (date) }\end{array}$ & $\begin{array}{c}\text { Last } \\
\text { (date) }\end{array}$ & $\begin{array}{c}\text { Peak } \\
\text { (date) }\end{array}$ & $\begin{array}{c}\text { Duration } \\
\text { (days) }\end{array}$ \\
\hline \multicolumn{6}{|c|}{ Spring Chinook Salmon } \\
\hline 1,905 & $1 / 1$ & $3 / 24$ & $5 / 29$ & $5 / 4$ & 149 \\
\hline \multicolumn{6}{|c|}{ Subyearling Chinook Salmon } \\
\hline 1,351 & $5 / 15(10 / 2)^{a}$ & $6 / 20$ & $7 / 10$ & $6 / 22$ & 57 \\
\hline \multicolumn{6}{|c|}{ Coho Salmon } \\
\hline 169 & $3 / 24(10 / 10)^{a}$ & $6 / 10$ & $7 / 9$ & $6 / 6$ & 108 \\
\hline \multicolumn{6}{|c|}{ Summer Steelhead } \\
\hline 1,227 & $1 / 16$ & $4 / 27$ & $6 / 22$ & $5 / 4$ & 158 \\
\hline
\end{tabular}

a Juvenile fish caught from October through December are part of the 2001 migration year, therefore they were not included in the migration duration calculation. 
Table 11. Detection, abundance, and survival of PIT-tagged production fish released into the upper Umatilla River and detected at Three Mile Falls Dam (RM 3.7), March - June 2002.

\begin{tabular}{|c|c|c|c|c|c|c|c|c|}
\hline Hatchery $^{a}$ & Raceway & $\begin{array}{c}\text { Volitional } \\
\text { release } \\
\text { date }\end{array}$ & $\begin{array}{c}\text { Release } \\
\text { site }\end{array}$ & $\begin{array}{l}\text { Release } \\
\text { number }\end{array}$ & $\begin{array}{l}\text { Detection } \\
\text { at RM } 3.7\end{array}$ & $\begin{array}{c}\text { Percent } \\
\text { detection }\end{array}$ & $\begin{array}{l}\text { Abun- } \\
\text { dance }^{b}\end{array}$ & $\begin{array}{c}\text { Percent } \\
\text { survival } \\
(95 \% \text { C.I.) }\end{array}$ \\
\hline \multicolumn{9}{|c|}{ Spring Chinook Salmon } \\
\hline UFH & $\mathrm{O} 4 \mathrm{~A}$ & $3 / 1 / 02$ & RM 80 & 297 & 28 & 9.4 & 284 & $95.6( \pm 42.9)$ \\
\hline UFH & $\mathrm{O} 4 \mathrm{~B}$ & $3 / 1 / 02$ & RM 80 & 299 & 27 & 9.0 & 249 & $83.3( \pm 59.2)$ \\
\hline UFH & $\mathrm{O} 5 \mathrm{~A}$ & $3 / 1 / 02$ & RM 80 & 299 & 33 & 11.0 & 281 & $94.0( \pm 54.4)$ \\
\hline UFH & O5B & $3 / 1 / 02$ & RM 80 & 298 & 29 & 9.7 & 227 & $76.2( \pm 37.8)$ \\
\hline UFH & M1A & $2 / 2 / 02$ & RM 80 & 298 & 1 & 0.3 & 12 & $4.0( \pm 8.4)$ \\
\hline UFH & M1B & $2 / 2 / 02$ & RM 80 & 297 & 2 & 0.7 & 24 & $8.1( \pm 13.0)$ \\
\hline UFH & $\mathrm{M} 1 \mathrm{C}$ & $2 / 2 / 02$ & RM 80 & 297 & 0 & 0.0 & 0 & $0.0( \pm 0.0)$ \\
\hline UFH & $\mathrm{M} 2 \mathrm{~A}$ & $3 / 1 / 02$ & RM 80 & 294 & 36 & 12.2 & 280 & $95.2( \pm 42.5)$ \\
\hline UFH & M2B & $3 / 1 / 02$ & RM 80 & 298 & 42 & 14.1 & 392 & 131.5 \\
\hline UFH & $\mathrm{M} 2 \mathrm{C}$ & $3 / 1 / 02$ & RM 80 & 299 & 37 & 12.4 & 332 & $111.0( \pm 71.5)$ \\
\hline WNFH & $41-45$ & $3 / 8 / 02$ & RM 80 & 289 & 18 & 6.2 & 79 & $27.3( \pm 16.1)$ \\
\hline WNFH & $\begin{array}{l}47-50 \\
21-22\end{array}$ & $4 / 4 / 02$ & RM 80 & 283 & 35 & 12.4 & 83 & $29.3( \pm 10.5)$ \\
\hline $\begin{array}{l}\text { Overall } \\
95 \% \text { C. I. }\end{array}$ & & & & & & & $\begin{array}{r}2243 \\
150.2\end{array}$ & $\begin{array}{c}63.2 \\
-76.2 \%)\end{array}$ \\
\hline
\end{tabular}

Yearling Fall Chinook Salmon

\begin{tabular}{|c|c|c|c|c|c|c|c|c|}
\hline $\mathrm{BFH}$ & A7-11 & $3 / 1 / 02$ & RM 73.5 & 287 & 55 & 19.2 & 273 & $95.1( \pm 31.1)$ \\
\hline $\mathrm{BFH}$ & A2-6 & $4 / 4 / 02$ & RM 73.5 & 286 & 19 & 6.6 & 73 & $24.8( \pm 11.8)$ \\
\hline $\begin{array}{l}\text { Overall } \\
95 \% \text { C.I. }\end{array}$ & & & & & & & $\begin{array}{l}346 \\
143 .\end{array}$ & $\begin{array}{c}60.4 \\
-77.1 \%)\end{array}$ \\
\hline
\end{tabular}

Subyearling Fall Chinook Salmon

\begin{tabular}{|c|c|c|c|c|c|c|c|c|}
\hline UFH & O1A & $5 / 17 / 02$ & RM 73.5 & 288 & 41 & 14.2 & 128 & $44.4( \pm 14.7)$ \\
\hline UFH & O1B & $5 / 17 / 02$ & RM 73.5 & 267 & 29 & 10.9 & 98 & $36.7( \pm 13.9)$ \\
\hline UFH & $\mathrm{O} 2 \mathrm{~A}$ & $5 / 23 / 02^{c}$ & $\mathrm{RM} 48.5$ & 297 & 155 & 52.2 & 295 & $99.3( \pm 17.5)$ \\
\hline UFH & $\mathrm{O} 2 \mathrm{~B}$ & $5 / 23 / 02^{c}$ & RM 48.5 & 299 & 137 & 45.8 & 263 & $88.0( \pm 15.8)$ \\
\hline $\begin{array}{l}\text { Overall } \\
95 \% \text { C.I. }\end{array}$ & & & & & & & $\begin{array}{r}784 \\
\quad 60\end{array}$ & $\begin{array}{c}68.1 \\
-75.9 \%)\end{array}$ \\
\hline
\end{tabular}

a $\quad B F H=$ Bonneville Fish Hatchery, $C F H=$ Carson National Fish Hatchery, HCFH $=$ Herman Creek Fish Hatchery, UFH = Umatilla Fish Hatchery, WNFH = Willard National Fish Hatchery.

${ }^{b} \quad$ Abundance $=$ abundance of PIT tagged fish. See Methods for abundance estimation method.

c Date of direct stream release. 
Table 11. Continued.

\begin{tabular}{|c|c|c|c|c|c|c|c|c|}
\hline Hatchery $^{a}$ & Pond & $\begin{array}{c}\text { Volitional } \\
\text { release } \\
\text { date }\end{array}$ & $\begin{array}{c}\text { Release } \\
\text { site }\end{array}$ & $\begin{array}{l}\text { Release } \\
\text { number }\end{array}$ & $\begin{array}{l}\text { Detection } \\
\text { at RM } 3.7\end{array}$ & $\begin{array}{c}\text { Percent } \\
\text { detection }\end{array}$ & $\begin{array}{l}\text { Abun- } \\
\text { dance }^{b}\end{array}$ & $\begin{array}{c}\text { Percent } \\
\text { survival } \\
(95 \% \text { C.I.) } \\
\end{array}$ \\
\hline \multicolumn{9}{|c|}{ Summer Steelhead } \\
\hline UFH & ${\mathrm{M} 8 \mathrm{~A}^{e}}$ & $4 / 24 / 02$ & RM 64.5 & 593 & 94 & 15.9 & 597 & $100.7( \pm 50.1)$ \\
\hline UFH & $\mathrm{AEX}^{e}$ & $4 / 29 / 02$ & RM 64.5 & 484 & 40 & 8.3 & 262 & $54.1( \pm 23.1)$ \\
\hline UFH & $\mathrm{M} 8 \mathrm{~B}^{f}$ & $4 / 24 / 02$ & RM 56 & 289 & 63 & 21.8 & 387 & $133.9( \pm 50.1)$ \\
\hline UFH & $\mathrm{BEX}^{f}$ & $4 / 30 / 02$ & RM 56 & 279 & 39 & 14.0 & 221 & $79.2( \pm 30.6)$ \\
\hline UFH & $\mathrm{M} 8 \mathrm{C}^{f}$ & $4 / 2 / 02$ & $\mathrm{RM} 79^{d}$ & 268 & 33 & 12.3 & 174 & $64.9( \pm 26.4)$ \\
\hline $\begin{array}{l}\text { Overall } \\
95 \% \text { C.I. }\end{array}$ & & & & & & & $\begin{array}{c}1641 \\
(70.4\end{array}$ & $\begin{array}{c}85.8 \\
-101.2 \%)\end{array}$ \\
\hline \multicolumn{9}{|c|}{ Coho Salmon } \\
\hline $\mathrm{CFH}$ & PE1 & $3 / 2 / 02$ & RM 56 & 300 & 23 & 7.7 & 112 & $37.3( \pm 16.8)$ \\
\hline $\mathrm{CFH}$ & PE32 & $4 / 5 / 02$ & RM 56 & 594 & 117 & 19.7 & 332 & $38.4( \pm 14.5)$ \\
\hline HCFH & PE31 & $3 / 2 / 02$ & RM 56 & 450 & 34 & 7.6 & 173 & $55.9( \pm 11.0)$ \\
\hline $\begin{array}{l}\text { Overall } \\
95 \% \text { C. I. }\end{array}$ & & & & & & & $\begin{array}{c}617 \\
(38.1 \\
\end{array}$ & $\begin{array}{r}45.9 \\
-53.7 \%) \\
\end{array}$ \\
\hline
\end{tabular}

${ }^{d}$ River mile 2 of Meacham Creek, which flows into river mile 79 of the Umatilla River.

e Small-grade summer steelhead.

$f$ Large-grade summer steelhead. 
Table 12. Binomial test for significant differences in detection of PIT tagged hatchery release groups, Umatilla River, 2002.

\begin{tabular}{|c|c|c|c|c|c|}
\hline $\begin{array}{l}\text { Release } \\
\text { group }\end{array}$ & Raceway & $\begin{array}{l}\text { No. Tags } \\
\text { released }\end{array}$ & $\begin{array}{l}\text { No. Tags } \\
\text { detected }^{a}\end{array}$ & $\begin{array}{l}\text { Probability of } \\
\text { detection }\end{array}$ & $\mathrm{t}$-value ${ }^{b}$ \\
\hline \multicolumn{6}{|c|}{ Spring Chinook Salmon } \\
\hline Michigan & $\mathrm{M} 2 \mathrm{~A}-\mathrm{C}$ & 891 & 275 & 0.309 & \multirow{2}{*}{1.275} \\
\hline Oregon & $\mathrm{O} 5 \mathrm{~A} / \mathrm{B}$ & 597 & 166 & 0.278 & \\
\hline Overwintered & $04 \mathrm{~A} / \mathrm{B}$ & 596 & 156 & 0.262 & \multirow[t]{2}{*}{0.635} \\
\hline Standard & $\mathrm{O} 5 \mathrm{~A} / \mathrm{B}$ & 597 & 166 & 0.278 & \\
\hline Early & WIL & 289 & 45 & 0.156 & \multirow[t]{2}{*}{1.845} \\
\hline Late & WI2 & 283 & 61 & 0.216 & \\
\hline Umatilla & All & 2084 & 597 & 0.714 & \multirow[t]{2}{*}{5.560} \\
\hline Willard & All & 289 & 45 & 0.844 & \\
\hline \multicolumn{6}{|c|}{ Yearling Fall Chinook Salmon } \\
\hline Early & A7-11 & 287 & 89 & 0.310 & \multirow[t]{2}{*}{0.244} \\
\hline Late & A2-6 & 286 & 86 & 0.301 & \\
\hline
\end{tabular}

Subyearling Fall Chinook Salmon

\begin{tabular}{|c|c|c|c|c|c|}
\hline Acclimated & O1A-B & 555 & 89 & 0.160 & 15.068 \\
\hline Direct-released & $\mathrm{O} 2 \mathrm{~A}-\mathrm{B}$ & 596 & 326 & 0.547 & \\
\hline \multicolumn{6}{|c|}{ Summer Steelhead } \\
\hline Standard & M8A/B & 882 & 201 & 0.228 & \multirow[t]{2}{*}{3.803} \\
\hline Ext. ${ }^{c}$ Rearing & $\mathrm{A} / \mathrm{BEX}$ & 763 & 118 & 0.155 & \\
\hline Small-grade & M8A/AEX & 1077 & 186 & 0.173 & \multirow[t]{2}{*}{2.902} \\
\hline Large-grade & M8B/BEX & 568 & 133 & 0.234 & \\
\hline Minthorn & M8A & 593 & 123 & 0.207 & \multirow[t]{2}{*}{1.362} \\
\hline Bonifer Springs & M8C & 268 & 67 & 0.250 & \\
\hline Minthorn & M8A/AEX & 1077 & 186 & 0.173 & \multirow[t]{2}{*}{2.902} \\
\hline Pendleton & M8B/BEX & 568 & 133 & 0.234 & \\
\hline Pendleton & M8B & 289 & 78 & 0.270 & \multirow[t]{2}{*}{0.535} \\
\hline Bonifer Springs & M8C & 268 & 67 & 0.250 & \\
\hline
\end{tabular}


Table 12. Continued.

\begin{tabular}{llllll}
$\begin{array}{l}\text { Release } \\
\text { group }\end{array}$ & Raceway & $\begin{array}{l}\text { No. Tags } \\
\text { released }\end{array}$ & $\begin{array}{l}\text { No. Tags } \\
\text { detected }\end{array}$ & $\begin{array}{l}\text { Probability of } \\
\text { detection }^{a}\end{array}$ & t-value $^{b}$ \\
\hline \multicolumn{5}{c}{ Coho Salmon } \\
Early & PE1 & 300 & 49 & 0.163 & $\mathbf{4 . 2 3 3}$ \\
Late & PE31 & 594 & 168 & 0.283 & \\
\hline
\end{tabular}


Table 13. Monthly abundance estimates for natural fish sampled in the lower Umatilla River, October 2001 - September 2002.

\begin{tabular}{|c|c|c|c|c|c|c|}
\hline Month $^{a}$ & $\begin{array}{l}\text { Number } \\
\text { sampled }\end{array}$ & $\begin{array}{c}\text { Adjusted } \\
\text { sample }^{b}\end{array}$ & $\begin{array}{c}\text { Percent } \\
\text { sample time }\end{array}$ & $\begin{array}{c}\text { Percent } \\
\text { diel }\end{array}$ & $\begin{array}{l}\text { Mean trap } \\
\text { efficiency }\end{array}$ & Abundance \\
\hline \multicolumn{7}{|c|}{ Chinook Salmon $^{c}$} \\
\hline October & 82 & 82 & 93.97 & 100.0 & 0.261 & 334 \\
\hline November & 8 & 8 & -- & -- & 0.027 & 296 \\
\hline December & 9 & 9 & -- & -- & 0.027 & 333 \\
\hline January & 29 & 29 & -- & -- & 0.027 & 1,074 \\
\hline February & 61 & 63 & -- & -- & 0.027 & 2,333 \\
\hline $\operatorname{March}^{e}$ & 721 & 870 & 43.69 & 99.36 & 0.147 & 15,967 \\
\hline April & 256 & 451 & 38.59 & 55.34 & 0.348 & 6,074 \\
\hline May & 95 & 273 & 8.62 & 41.68 & 0.704 & 10,794 \\
\hline June & 0 & 1036 & 61.93 & 100.0 & 0.261 & 6,413 \\
\hline July & 0 & 199 & 35.00 & 100.0 & 0.340 & 1671 \\
\hline August & -- & -- & -- & -- & -- & -- \\
\hline September & -- & -- & -- & -- & -- & -- \\
\hline Total & & & & & & $45,289_{( \pm 5,361)}$ \\
\hline \multicolumn{7}{|c|}{ Coho Salmon $^{d}$} \\
\hline October & 2 & 2 & 93.97 & 100.0 & 0.340 & 6 \\
\hline November & 3 & 3 & -- & -- & 0.027 & 115 \\
\hline December & 4 & 4 & -- & -- & 0.027 & 153 \\
\hline January & -- & -- & -- & -- & -- & -- \\
\hline February & -- & -- & -- & -- & -- & -- \\
\hline March & 1 & 1 & 43.69 & 94.47 & 0.124 & 20 \\
\hline April & 15 & 20 & 38.59 & 42.55 & 0.247 & 492 \\
\hline May & 10 & 31 & 8.62 & 35.78 & 0.336 & 2,990 \\
\hline June & 82 & 82 & 61.93 & 100.0 & 0.261 & 508 \\
\hline July & 19 & 19 & 35.00 & 100.0 & 0.340 & 160 \\
\hline Total & & & & & & $4,444( \pm 485)$ \\
\hline \multicolumn{7}{|c|}{ Summer Steelhead } \\
\hline January & 2 & 2 & -- & -- & 0.010 & 400 \\
\hline February & 10 & 10 & -- & -- & 0.010 & 2000 \\
\hline $\operatorname{March}^{e}$ & 117 & 227 & 43.69 & 100.0 & 0.221 & 3,862 \\
\hline April & 191 & 387 & 38.59 & 24.50 & 0.385 & 10,640 \\
\hline May & 245 & 514 & 8.62 & 37.04 & 0.273 & 58,999 \\
\hline June & 67 & 67 & 61.93 & 100.0 & 0.097 & 1,115 \\
\hline Total & & & & & & $77,016_{( \pm 7,821)}$ \\
\hline
\end{tabular}

a October-December comprises part of the 2001 migration season for chinook and coho salmon and MarchSeptember part of the 2002 season.

$b \quad$ Number sampled was expanded by sample rate to provide a fish passage index.

$c$ Includes both race (spring and fall) and age classes ( $0+$ and $1+$ ) of fish.

${ }^{d}$ Natural coho salmon were identified as such in the field due to size, condition, and markings. Estimate may not be accurate due to large number of coho of undetermined origin sampled.

e March estimates include mixture of data collected from both West Extension Canal and rotary screw trap. 
Table 14. Percent holding survival and tag retention of hatchery and natural juvenile salmonids tagged for trap efficiency tests at RM 3.7, Umatilla River, Spring 2002.

\begin{tabular}{|c|c|c|c|c|c|c|c|}
\hline $\begin{array}{l}\text { Mark } \\
\text { date }\end{array}$ & $\begin{array}{l}\text { Number } \\
\text { tagged }^{a}\end{array}$ & $\begin{array}{c}\text { Mean } \\
\text { temperature }^{b}\end{array}$ & $\begin{array}{c}\text { Hours } \\
\text { held }\end{array}$ & $\begin{array}{c}\text { Number } \\
\text { mortalities }\end{array}$ & $\begin{array}{c}\text { Number of } \\
\text { lost tags }\end{array}$ & $\begin{array}{c}\text { Percent } \\
\text { holding }^{\text {survival }} \\
\text { survive }^{c}\end{array}$ & $\begin{array}{l}\text { Percent } \\
\text { tag } \\
\text { retention }\end{array}$ \\
\hline \multicolumn{8}{|c|}{ Hatchery } \\
\hline \multicolumn{8}{|c|}{ Spring Chinook Salmon } \\
\hline $3 / 11$ & 100 & 9.1 & 22.5 & 0 & 0 & 100.0 & 100.0 \\
\hline $3 / 13$ & 100 & -- & 24.2 & 0 & 0 & 100.0 & 100.0 \\
\hline $3 / 15$ & 60 & 6.4 & 26.3 & 1 & 0 & 98.3 & 100.0 \\
\hline $3 / 17$ & 75 & 6.3 & 49.7 & 0 & 0 & 100.0 & 100.0 \\
\hline $3 / 20$ & 98 & 5.8 & 24.5 & 0 & 0 & 100.0 & 100.0 \\
\hline $3 / 24$ & 125 & 7.3 & 48.9 & 1 & 0 & 99.2 & 100.0 \\
\hline $3 / 30$ & 100 & 10.9 & 21.2 & 0 & 0 & 100.0 & 100.0 \\
\hline $4 / 03$ & 60 & 9.8 & 27.1 & 0 & 0 & 100.0 & 100.0 \\
\hline $4 / 07$ & 75 & 10.0 & 29.2 & 0 & 0 & 100.0 & 100.0 \\
\hline $4 / 12$ & 143 & 11.0 & 49.3 & 0 & 0 & 100.0 & 100.0 \\
\hline $4 / 18$ & 60 & 10.7 & 28.9 & 0 & 0 & 100.0 & 100.0 \\
\hline $4 / 21$ & 50 & 12.0 & 25.5 & 0 & 0 & 100.0 & 100.0 \\
\hline $4 / 24$ & 40 & 11.4 & 24.7 & 0 & 0 & 100.0 & 100.0 \\
\hline $4 / 28$ & 30 & 14.0 & 22.0 & 0 & 0 & 100.0 & 100.0 \\
\hline $5 / 01$ & 25 & 15.4 & 25.3 & 0 & 0 & 100.0 & 100.0 \\
\hline $5 / 04$ & 30 & 11.6 & 19.7 & 0 & 0 & 100.0 & 100.0 \\
\hline $5 / 08$ & 25 & 14.1 & 23.4 & 0 & 0 & 100.0 & 100.0 \\
\hline $5 / 11$ & 25 & 16.0 & 24.6 & 0 & 0 & 100.0 & 100.0 \\
\hline Total & 1221 & & & & Overall & 99.8 & 100.0 \\
\hline \multicolumn{8}{|c|}{ Yearling Fall Chinook Salmon } \\
\hline $3 / 11$ & 99 & 9.1 & 21.8 & 0 & 1 & 100.0 & 99.0 \\
\hline $3 / 13$ & 99 & -- & 23.3 & 1 & 0 & 98.9 & 100.0 \\
\hline $3 / 16$ & 45 & 5.6 & 25.5 & 0 & 0 & 100.0 & 100.0 \\
\hline $3 / 20$ & 60 & 5.9 & 23.5 & 0 & 0 & 100.0 & 100.0 \\
\hline $3 / 24$ & 100 & 7.3 & 48.3 & 0 & 0 & 100.0 & 100.0 \\
\hline $3 / 30$ & 98 & 11.5 & 20.4 & 3 & 0 & 96.9 & 100.0 \\
\hline $4 / 03$ & 60 & 10.0 & 26.3 & 0 & 0 & 100.0 & 100.0 \\
\hline $4 / 07$ & 75 & 10.0 & 23.7 & 0 & 0 & 100.0 & 100.0 \\
\hline $4 / 13$ & 133 & 11.5 & 25.5 & 0 & 0 & 100.0 & 100.0 \\
\hline $4 / 18$ & 60 & 10.6 & 29.4 & 0 & 0 & 100.0 & 100.0 \\
\hline $4 / 21$ & 50 & 12.0 & 26.3 & 0 & 0 & 100.0 & 100.0 \\
\hline $4 / 24$ & 47 & 11.3 & 27.1 & 0 & 0 & 100.0 & 100.0 \\
\hline $4 / 28$ & 40 & 14.0 & 21.4 & 0 & 0 & 100.0 & 100.0 \\
\hline $5 / 01$ & 30 & 15.4 & 25.0 & 0 & 0 & 100.0 & 100.0 \\
\hline $5 / 10$ & 25 & 15.8 & 24.3 & 1 & 0 & 96.0 & 100.0 \\
\hline Total & 1021 & & & & Overall & 99.5 & 99.9 \\
\hline
\end{tabular}


Table 14. Continued.

\begin{tabular}{|c|c|c|c|c|c|c|c|}
\hline $\begin{array}{l}\text { Mark } \\
\text { date }\end{array}$ & $\begin{array}{l}\text { Number } \\
\text { tagged }^{a}\end{array}$ & $\begin{array}{c}\text { Mean } \\
\text { temperature }^{b}\end{array}$ & $\begin{array}{c}\text { Hours } \\
\text { held }\end{array}$ & $\begin{array}{c}\text { Number } \\
\text { mortalities }\end{array}$ & $\begin{array}{c}\text { Number of } \\
\text { lost tags }\end{array}$ & $\begin{array}{c}\text { Percent } \\
\text { holding } \\
\text { survival }^{c}\end{array}$ & $\begin{array}{l}\text { Percent } \\
\text { tag } \\
\text { retention }\end{array}$ \\
\hline \multicolumn{8}{|c|}{ Subyearling Fall Chinook Salmon } \\
\hline $5 / 22$ & 50 & 14.5 & 28.3 & 0 & 0 & 100.0 & 100.0 \\
\hline $5 / 23$ & 25 & 16.3 & 24.4 & 0 & 0 & 100.0 & 100.0 \\
\hline $5 / 23$ & 25 & 16.8 & 49.9 & 0 & 0 & 100.0 & 100.0 \\
\hline $5 / 25$ & 25 & 18.3 & 28.6 & 0 & 0 & 100.0 & 100.0 \\
\hline $5 / 25$ & 25 & 18.3 & 49.7 & 0 & 0 & 100.0 & 100.0 \\
\hline $5 / 28$ & 20 & 19.0 & 1.5 & 0 & 0 & 100.0 & 100.0 \\
\hline $5 / 28$ & 20 & 20.0 & 28.6 & 0 & 0 & 100.0 & 100.0 \\
\hline $5 / 30$ & 20 & 20.0 & 28.5 & 0 & 0 & 100.0 & 100.0 \\
\hline $5 / 30$ & 20 & 19.5 & 50.6 & 0 & 0 & 100.0 & 100.0 \\
\hline $6 / 01$ & 40 & 19.5 & 49.3 & 16 & 0 & 60.0 & 100.0 \\
\hline $6 / 05$ & 40 & 20.5 & 6.4 & 0 & 0 & 100.0 & 100.0 \\
\hline $6 / 05$ & 40 & 20.3 & 29.1 & 0 & 0 & 100.0 & 100.0 \\
\hline $6 / 07$ & 39 & 18.8 & 4.2 & 0 & 0 & 100.0 & 100.0 \\
\hline $6 / 07$ & 39 & 18.3 & 30.8 & 0 & 0 & 100.0 & 100.0 \\
\hline $6 / 12$ & 40 & 21.3 & 29.7 & 4 & 0 & 90.0 & 100.0 \\
\hline $6 / 19$ & 40 & 18.8 & 22.2 & 2 & 0 & 95.0 & 100.0 \\
\hline Total & 508 & & & & Overall & 95.7 & 100.0 \\
\hline \multicolumn{8}{|c|}{ Summer Steelhead } \\
\hline $4 / 11$ & 150 & 11.0 & 51.8 & 4 & 0 & 97.3 & 100.0 \\
\hline $4 / 16$ & 114 & 9.5 & 25.9 & 0 & 0 & 100.0 & 100.0 \\
\hline $4 / 19$ & 52 & 11.7 & 30.4 & 0 & 0 & 100.0 & 100.0 \\
\hline $4 / 19$ & 58 & 11.0 & 52.9 & 0 & 0 & 100.0 & 100.0 \\
\hline $4 / 24$ & 51 & 11.7 & 24.9 & 0 & 1 & 100.0 & 98.1 \\
\hline $4 / 26$ & 27 & 13.1 & 19.8 & 0 & 0 & 100.0 & 100.0 \\
\hline $5 / 4$ & 50 & 11.7 & 21.8 & 0 & 0 & 100.0 & 100.0 \\
\hline $5 / 4$ & 50 & 11.7 & 21.4 & 0 & 0 & 100.0 & 100.0 \\
\hline $5 / 8$ & 35 & 14.1 & 22.6 & 0 & 0 & 100.0 & 100.0 \\
\hline $5 / 15$ & 50 & 17.3 & 23.4 & 1 & 0 & 98.0 & 100.0 \\
\hline $5 / 18$ & 34 & 17.3 & 50.4 & 0 & 0 & 100.0 & 100.0 \\
\hline $5 / 22$ & 60 & 14.5 & 29.5 & 0 & 0 & 100.0 & 100.0 \\
\hline $5 / 25$ & 44 & 18.0 & 29.5 & 0 & 1 & 100.0 & 97.8 \\
\hline $5 / 30$ & 38 & 19.8 & 29.7 & 0 & 2 & 100.0 & 95.0 \\
\hline $6 / 1$ & 40 & 19.5 & 51.6 & 2 & 0 & 95.0 & 100.0 \\
\hline $6 / 7$ & 38 & 18.3 & 31.8 & 1 & 2 & 97.4 & 95.0 \\
\hline Total & 891 & & & & Overall & 99.1 & 99.3 \\
\hline
\end{tabular}


Table 14. Continued.

\begin{tabular}{|c|c|c|c|c|c|c|c|}
\hline $\begin{array}{l}\text { Mark } \\
\text { date }\end{array}$ & $\begin{array}{l}\text { Number } \\
\text { tagged }^{a}\end{array}$ & $\begin{array}{c}\text { Mean } \\
\text { temperature }^{b}\end{array}$ & $\begin{array}{c}\text { Hours } \\
\text { held }\end{array}$ & $\begin{array}{c}\text { Number } \\
\text { mortalities }\end{array}$ & $\begin{array}{c}\text { Number of } \\
\text { lost tags }\end{array}$ & $\begin{array}{c}\text { Percent } \\
\text { holding } \\
\text { survival }^{c}\end{array}$ & $\begin{array}{c}\text { Percent tag } \\
\text { retention }\end{array}$ \\
\hline \multicolumn{8}{|c|}{ Unknown } \\
\hline $3 / 16$ & 75 & 5.8 & 29.3 & 0 & 0 & 100.0 & 100.0 \\
\hline $3 / 24$ & 100 & 7.3 & 47.9 & 0 & 0 & 100.0 & 100.0 \\
\hline $3 / 27$ & 133 & 8.7 & 25.7 & 0 & 0 & 100.0 & 100.0 \\
\hline $3 / 29$ & 118 & 10.3 & 29.8 & 0 & 0 & 100.0 & 100.0 \\
\hline $4 / 3$ & 60 & 9.4 & 27.5 & 0 & 0 & 100.0 & 100.0 \\
\hline $4 / 7$ & 75 & 10.0 & 24.5 & 0 & 0 & 100.0 & 100.0 \\
\hline $4 / 14$ & 150 & 10.0 & 48.8 & 0 & 0 & 100.0 & 100.0 \\
\hline $4 / 19$ & 65 & 10.6 & 6.0 & 0 & 0 & 100.0 & 100.0 \\
\hline $4 / 21$ & 50 & 12.0 & 25.0 & 0 & 0 & 100.0 & 100.0 \\
\hline $4 / 24$ & 55 & 11.4 & 24.1 & 0 & 0 & 100.0 & 100.0 \\
\hline $4 / 28$ & 50 & 14.0 & 22.6 & 0 & 0 & 100.0 & 100.0 \\
\hline $5 / 1$ & 50 & 15.4 & 25.8 & 0 & 0 & 100.0 & 100.0 \\
\hline $5 / 4$ & 50 & 11.6 & 19.9 & 0 & 0 & 100.0 & 100.0 \\
\hline $5 / 8$ & 30 & 14.1 & 23.8 & 0 & 0 & 100.0 & 100.0 \\
\hline $5 / 11$ & 30 & 16.0 & 24.8 & 0 & 0 & 100.0 & 100.0 \\
\hline $5 / 15$ & 30 & 17.3 & 23.9 & 0 & 0 & 100.0 & 100.0 \\
\hline $5 / 22$ & 40 & 14.5 & 29.0 & 0 & 0 & 100.0 & 100.0 \\
\hline $5 / 25$ & 45 & 18.3 & 29.0 & 0 & 0 & 100.0 & 100.0 \\
\hline Total & 1206 & & & & Overall & 100.0 & 100.0 \\
\hline \multicolumn{8}{|c|}{ Natural } \\
\hline $3 / 16$ & 60 & 5.6 & 26.0 & 0 & 0 & 100.0 & 100.0 \\
\hline $3 / 19$ & 79 & 6.7 & 25.5 & 0 & 0 & 100.0 & 100.0 \\
\hline $3 / 22$ & 31 & 5.8 & 23.5 & 0 & 0 & 100.0 & 100.0 \\
\hline $3 / 24$ & 68 & 7.3 & 47.3 & 0 & 0 & 100.0 & 100.0 \\
\hline $4 / 4$ & 61 & 10.5 & 25.2 & 0 & 0 & 100.0 & 100.0 \\
\hline $4 / 9$ & 26 & -- & 25.3 & 1 & 0 & 96.2 & 100.0 \\
\hline $4 / 20$ & 29 & 12.0 & 47.8 & 0 & 0 & 100.0 & 100.0 \\
\hline $4 / 24$ & 27 & 11.5 & 25.7 & 0 & 0 & 100.0 & 100.0 \\
\hline $4 / 26$ & 32 & 13.0 & 20.9 & 0 & 0 & 100.0 & 100.0 \\
\hline $5 / 1$ & 33 & 15.3 & 26.3 & 0 & 0 & 100.0 & 100.0 \\
\hline $5 / 18$ & 13 & 17.3 & 49.6 & 0 & 0 & 100.0 & 100.0 \\
\hline $6 / 12$ & 26 & 21.3 & 30.7 & 2 & 0 & 92.3 & 100.0 \\
\hline $6 / 19$ & 58 & 18.8 & 23.3 & 1 & 0 & 98.3 & 100.0 \\
\hline Total & 543 & & & & Overall & 99.3 & 100.0 \\
\hline
\end{tabular}


Table 14. Continued.

\begin{tabular}{|c|c|c|c|c|c|c|c|}
\hline $\begin{array}{l}\text { Mark } \\
\text { date }\end{array}$ & $\begin{array}{l}\text { Number } \\
\text { tagged }^{a}\end{array}$ & $\begin{array}{c}\text { Mean } \\
\text { temperature }^{b}\end{array}$ & $\begin{array}{c}\text { Hours } \\
\text { held }\end{array}$ & $\begin{array}{c}\text { Number } \\
\text { mortalities }\end{array}$ & $\begin{array}{c}\text { Number of } \\
\text { lost tags }\end{array}$ & $\begin{array}{c}\text { Percent } \\
\text { holding } \\
\text { survival }^{c}\end{array}$ & $\begin{array}{c}\text { Percent tag } \\
\text { retention }\end{array}$ \\
\hline \multicolumn{8}{|c|}{ Summer Steelhead } \\
\hline $4 / 4$ & 43 & 10.3 & 25.7 & 0 & 0 & 100.0 & 100.0 \\
\hline $4 / 9$ & 38 & -- & 25.7 & 0 & 0 & 100.0 & 100.0 \\
\hline $4 / 27$ & 21 & 13.3 & 53.2 & 0 & 0 & 100.0 & 100.0 \\
\hline $5 / 16$ & 47 & 17.0 & 24.4 & 0 & 0 & 100.0 & 100.0 \\
\hline $5 / 18$ & 35 & 17.3 & 50.0 & 0 & 0 & 100.0 & 100.0 \\
\hline $5 / 22$ & 29 & 14.8 & 27.6 & 0 & 0 & 100.0 & 100.0 \\
\hline $5 / 24$ & 23 & 17.3 & 26.0 & 0 & 0 & 100.0 & 100.0 \\
\hline $5 / 30$ & 35 & 19.8 & 30.6 & 0 & 0 & 100.0 & 100.0 \\
\hline Total & 271 & & & & & 100.0 & 100.0 \\
\hline
\end{tabular}


Table 15. Trap efficiency estimates, mean travel time, and detection information for hatchery and natural juvenile salmonids, West Extension Canal (RM 3.7), March - June 2002.

\begin{tabular}{|c|c|c|c|c|c|c|c|c|c|c|}
\hline \multirow{2}{*}{$\begin{array}{l}\text { Release } \\
\text { date }\end{array}$} & \multirow{2}{*}{$\begin{array}{c}\text { Number }^{a} \\
\text { released }\end{array}$} & \multirow{2}{*}{$\begin{array}{c}\text { Release } \\
\text { temp } \\
\left({ }^{\circ} \mathrm{C}\right)\end{array}$} & \multicolumn{5}{|c|}{$\begin{array}{l}\text { Number detected by } \\
\text { days after release }\end{array}$} & \multirow{2}{*}{$\begin{array}{c}\text { Mean } \\
\text { travel time } \\
(\mathrm{mi} / \mathrm{d})\end{array}$} & \multirow{2}{*}{$\begin{array}{c}\text { Trap } \\
\text { efficiency } \\
(\mathrm{TE})\end{array}$} & \multirow{2}{*}{$\begin{array}{l}\text { Pooled } \\
\text { TE }^{\mathrm{b}}\end{array}$} \\
\hline & & & $0-5$ & $6-10$ & $11-15$ & $16-20$ & $>20$ & & & \\
\hline \multicolumn{11}{|c|}{ Hatchery } \\
\hline $3 / 12$ & 100 & 13.8 & 16 & 0 & 0 & 0 & 1 & 5.5 & 0.170 & 0.170 \\
\hline $3 / 14$ & 100 & 10.0 & 2 & 1 & 2 & 0 & 0 & 1.1 & 0.050 & 0.050 \\
\hline $3 / 16$ & 58 & 11.2 & 6 & 2 & 3 & 1 & 1 & 0.2 & 0.224 & 0.218 \\
\hline $3 / 19$ & 75 & 14.0 & 14 & 2 & 0 & 0 & 0 & 4.2 & 0.213 & 0.218 \\
\hline $3 / 21$ & 98 & 11.9 & 20 & 0 & 0 & 3 & 2 & 3.1 & 0.255 & 0.118 \\
\hline $3 / 26$ & 123 & 7.9 & 0 & 0 & 0 & 1 & 0 & 0.1 & 0.008 & 0.118 \\
\hline $3 / 31$ & 100 & 12.5 & 24 & 3 & 0 & 0 & 1 & 2.8 & 0.280 & 0.280 \\
\hline $4 / 4$ & 60 & 12.0 & 29 & 2 & 0 & 0 & 0 & 2.6 & 0.517 & 0.517 \\
\hline $4 / 8$ & 75 & 11.0 & 15 & 0 & 1 & 0 & 0 & 2.2 & 0.213 & 0.083 \\
\hline $4 / 14$ & 143 & 11.0 & 2 & 0 & 0 & 0 & 0 & 18.5 & 0.014 & 0.083 \\
\hline $4 / 19$ & 60 & 14.5 & 32 & 4 & 0 & 0 & 0 & 4.2 & 0.600 & 0.620 \\
\hline $4 / 22$ & 50 & 15.0 & 29 & 4 & 0 & 0 & 0 & 2.5 & 0.660 & 0.620 \\
\hline $4 / 25$ & 40 & 12.2 & 24 & 0 & 0 & 0 & 0 & 2.2 & 0.600 & 0.620 \\
\hline $4 / 29$ & 30 & 17.0 & 10 & 0 & 0 & 0 & 0 & 3.9 & 0.333 & 0.365 \\
\hline $5 / 2$ & 25 & 15.5 & 8 & 0 & 0 & 0 & 0 & 2.9 & 0.320 & 0.365 \\
\hline $5 / 5$ & 30 & 14.0 & 13 & 0 & 0 & 0 & 0 & 10.2 & 0.433 & 0.365 \\
\hline $5 / 9$ & 25 & 17.2 & 16 & 0 & 1 & 0 & 0 & 4.5 & 0.680 & 0.580 \\
\hline $5 / 12$ & 25 & 18.4 & 12 & 0 & 0 & 0 & 0 & 3.3 & 0.480 & 0.580 \\
\hline & & & & & & & & ooled & $0.320(S$ & $=0.205)$ \\
\hline
\end{tabular}

Yearling Fall Chinook Salmon

\begin{tabular}{lcccccccccc}
$3 / 12$ & 99 & 13.8 & 16 & 0 & 1 & 0 & 3 & 4.1 & 0.202 & 0.199 \\
$3 / 14$ & 97 & 10.0 & 8 & 3 & 1 & 1 & 6 & 2.5 & 0.196 & 0.199 \\
$3 / 17$ & 45 & 12.6 & 11 & 0 & 0 & 1 & 3 & 0.3 & 0.333 & 0.333 \\
$3 / 21$ & 60 & 11.9 & 12 & 4 & 1 & 2 & 2 & 1.1 & 0.350 & 0.144 \\
$3 / 26$ & 100 & 7.9 & 1 & 0 & 0 & 0 & 1 & 2.7 & 0.020 & 0.144 \\
$3 / 31$ & 92 & 12.5 & 21 & 3 & 1 & 2 & 0 & 1.2 & 0.293 & 0.293 \\
$4 / 4$ & 60 & 12.0 & 28 & 1 & 1 & 0 & 0 & 3.7 & 0.500 & 0.500 \\
$4 / 8$ & 75 & 11.0 & 12 & 1 & 1 & 0 & 0 & 0.8 & 0.187 & 0.153 \\
$4 / 14$ & 133 & 11.0 & 2 & 0 & 0 & 0 & 0 & -- & 0.015 & 0.153 \\
$4 / 19$ & 60 & 14.5 & 20 & 4 & 1 & 0 & 0 & 1.6 & 0.417 & 0.153 \\
$4 / 22$ & 50 & 15.0 & 18 & 0 & 0 & 1 & 0 & 2.0 & 0.380 & 0.332 \\
$4 / 25$ & 47 & 12.2 & 11 & 1 & 0 & 0 & 0 & 0.9 & 0.255 & 0.332 \\
$4 / 29$ & 40 & 17.0 & 9 & 3 & 0 & 0 & 0 & 0.9 & 0.300 & 0.332 \\
$5 / 2$ & 30 & 15.5 & 10 & 3 & 0 & 0 & 0 & 2.2 & 0.433 & 0.332 \\
$5 / 11$ & 23 & 17.8 & 7 & 0 & 0 & 0 & 0 & 3.9 & 0.304 & 0.332 \\
& & & & & & & Mean pooled TE $=0.262(S D=0.103)$ \\
\hline
\end{tabular}

a Number released is adjusted by the expected survival of test fish; see Methods.

$b \quad$ Pooled TE was based on results of Chi ${ }^{2}$ tests; see Methods. 
Table 15. Continued.

\begin{tabular}{|c|c|c|c|c|c|c|c|c|c|c|}
\hline \multirow{2}{*}{$\begin{array}{l}\text { Release } \\
\text { date }\end{array}$} & \multirow{2}{*}{$\begin{array}{l}\text { Number }^{a} \\
\text { released }\end{array}$} & \multirow{2}{*}{$\begin{array}{l}\text { Release } \\
\text { temp } \\
\left({ }^{\circ} \mathrm{C}\right)\end{array}$} & \multicolumn{5}{|c|}{$\begin{array}{l}\text { Number detected by } \\
\text { days after release }\end{array}$} & \multirow{2}{*}{$\begin{array}{l}\text { Mean } \\
\text { travel time } \\
(\mathrm{mi} / \mathrm{d})\end{array}$} & \multirow{2}{*}{$\begin{array}{c}\text { Trap } \\
\text { efficiency } \\
\text { (TE) }\end{array}$} & \multirow{2}{*}{$\begin{array}{l}\text { Pooled } \\
\mathrm{TE}^{b}\end{array}$} \\
\hline & & & $0-5$ & $6-10$ & $11-15$ & $16-20$ & $>20$ & & & \\
\hline \multicolumn{11}{|c|}{ Subyearling Fall Chinook Salmon } \\
\hline $5 / 23$ & 50 & 17.5 & 34 & 0 & 0 & 0 & 0 & 6.4 & 0.68 & 0.664 \\
\hline $5 / 24$ & 25 & 18.5 & 19 & 0 & 0 & 0 & 0 & 8.7 & 0.76 & 0.664 \\
\hline $5 / 25$ & 25 & 18.2 & 19 & 0 & 0 & 0 & 0 & 6.4 & 0.76 & 0.664 \\
\hline $5 / 26$ & 25 & 18.3 & 11 & 0 & 0 & 0 & 0 & 2.8 & 0.44 & 0.664 \\
\hline $5 / 27$ & 25 & 18.3 & 8 & 0 & 0 & 0 & 0 & 4.9 & 0.32 & 0.252 \\
\hline $5 / 28$ & 20 & 18.5 & 2 & 0 & 0 & 0 & 0 & 1.2 & 0.1 & 0.252 \\
\hline $5 / 29$ & 20 & 18.5 & 2 & 0 & 0 & 0 & 0 & 2.8 & 0.1 & 0.252 \\
\hline $5 / 31$ & 20 & 19.5 & 4 & 0 & 0 & 0 & 0 & 2.9 & 0.2 & 0.252 \\
\hline $6 / 1$ & 20 & 18.5 & 4 & 0 & 0 & 0 & 0 & 4.2 & 0.2 & 0.252 \\
\hline $6 / 3$ & 14 & 20.0 & 3 & 1 & 0 & 0 & 0 & 1.0 & 0.278 & 0.252 \\
\hline $6 / 5$ & 40 & 20.0 & 12 & 0 & 0 & 0 & 0 & 1.0 & 0.3 & 0.252 \\
\hline $6 / 6$ & 40 & 19.0 & 9 & 2 & 1 & 0 & 0 & 5.1 & 0.3 & 0.252 \\
\hline $6 / 7$ & 39 & 16.5 & 12 & 0 & 0 & 0 & 0 & 5.3 & 0.308 & 0.252 \\
\hline \multirow[t]{2}{*}{$6 / 8$} & 39 & 17.5 & 7 & 0 & 0 & 0 & 0 & 1.4 & 0.179 & 0.252 \\
\hline & & & & & & & \multicolumn{4}{|c|}{ Mean pooled $T E=0.369(S D=0.186)$} \\
\hline
\end{tabular}

Summer Steelhead

$\begin{array}{lcccccccccr}4 / 13 & 142 & 11.5 & 2 & 3 & 5 & 7 & 8 & 0.1 & 0.176 & 0.176 \\ 4 / 17 & 114 & 10.5 & 5 & 3 & 10 & 2 & 11 & 0.2 & 0.272 & 0.272 \\ 4 / 20 & 52 & 14.5 & 12 & 5 & 4 & 1 & 2 & 2.1 & 0.462 & 0.462 \\ 4 / 21 & 58 & 15.5 & 7 & 1 & 1 & 1 & 1 & 2.3 & 0.190 & 0.190 \\ 4 / 25 & 51 & 12.2 & 20 & 1 & 0 & 3 & 2 & 2.3 & 0.510 & 0.423 \\ 4 / 27 & 27 & 15.2 & 4 & 3 & 0 & 0 & 0 & 1.7 & 0.259 & 0.423 \\ 5 / 5 & 50 & 14.0 & 6 & 4 & 4 & 0 & 0 & 4.0 & 0.28 & 0.193 \\ 5 / 5 & 50 & 14.0 & 5 & 2 & 1 & 0 & 1 & 1.3 & 0.18 & 0.193 \\ 5 / 9 & 35 & 17.2 & 3 & 0 & 0 & 0 & 0 & 1.1 & 0.086 & 0.193 \\ 5 / 16 & 48 & 17.5 & 3 & 0 & 0 & 0 & 0 & 1.1 & 0.062 & 0.140 \\ 5 / 20 & 34 & 17.5 & 5 & 0 & 0 & 0 & 0 & 3.5 & 0.147 & 0.140 \\ 5 / 23 & 60 & 17.5 & 8 & 1 & 0 & 0 & 0 & 2.4 & 0.15 & 0.140 \\ 5 / 26 & 44 & 18.3 & 9 & 0 & 0 & 0 & 0 & 2.8 & 0.205 & 0.140 \\ & & & & & & & \text { Mean pooled TE }=0.211(S D=0.116)\end{array}$

Unmarked

Coho Salmon

\begin{tabular}{lcccccccccc}
$3 / 17$ & 75 & 12.6 & 6 & 3 & 0 & 0 & 1 & 0.2 & 0.133 & 0.129 \\
$3 / 26$ & 100 & 7.9 & 2 & 0 & 0 & 0 & 2 & 19.2 & 0.04 & 0.129 \\
$3 / 28$ & 133 & 9.6 & 22 & 0 & 1 & 3 & 2 & 6.7 & 0.211 & 0.129 \\
$3 / 30$ & 118 & 11.3 & 8 & 0 & 2 & 2 & 1 & 3.0 & 0.110 & 0.129 \\
$4 / 4$ & 60 & 12.0 & 14 & 0 & 0 & 0 & 0 & 5.5 & 0.233 & 0.185 \\
$4 / 8$ & 75 & 11.0 & 7 & 2 & 0 & 1 & 1 & 2.8 & 0.147 & 0.185 \\
$4 / 16$ & 150 & 8.5 & 16 & 0 & 0 & 0 & 0 & 15.4 & 0.107 & 0.107 \\
\hline
\end{tabular}


Table 15. Continued.

\begin{tabular}{|c|c|c|c|c|c|c|c|c|c|c|}
\hline \multirow{2}{*}{$\begin{array}{l}\text { Release } \\
\text { date }\end{array}$} & \multirow{2}{*}{$\begin{array}{l}\text { Number }^{a} \\
\text { released }\end{array}$} & \multirow{2}{*}{$\begin{array}{c}\text { Release } \\
\text { temp } \\
\left({ }^{\circ} \mathrm{C}\right)\end{array}$} & \multicolumn{5}{|c|}{$\begin{array}{l}\text { Number detected by } \\
\text { days after release }\end{array}$} & \multirow{2}{*}{$\begin{array}{c}\text { Mean } \\
\text { travel time } \\
(\mathrm{mi} / \mathrm{d})\end{array}$} & \multirow{2}{*}{$\begin{array}{c}\text { Trap } \\
\text { efficiency } \\
\text { (TE) }\end{array}$} & \multirow{2}{*}{$\begin{array}{l}\text { Poole } \\
\mathrm{TE}^{b}\end{array}$} \\
\hline & & & $0-5$ & $6-10$ & $11-15$ & $16-20$ & $>20$ & & & \\
\hline \multicolumn{11}{|c|}{ Coho Salmon } \\
\hline $4 / 19$ & 65 & 14.5 & 8 & 5 & 7 & 3 & 1 & 2.2 & 0.369 & 0.369 \\
\hline $4 / 22$ & 50 & 15.0 & 8 & 1 & 0 & 0 & 0 & 1.2 & 0.18 & 0.210 \\
\hline $4 / 25$ & 55 & 12.2 & 12 & 1 & 0 & 0 & 0 & 0.6 & 0.236 & 0.210 \\
\hline $4 / 29$ & 50 & 17.0 & 23 & 0 & 0 & 0 & 0 & 1.6 & 0.46 & 0.42 \\
\hline $5 / 2$ & 50 & 15.5 & 16 & 1 & 0 & 0 & 0 & 1.6 & 0.34 & 0.42 \\
\hline $5 / 5$ & 50 & 14.0 & 21 & 1 & 1 & 0 & 0 & 2.7 & 0.46 & 0.42 \\
\hline $5 / 9$ & 30 & 17.2 & 6 & 0 & 0 & 0 & 0 & 1.4 & 0.2 & 0.32 \\
\hline $5 / 12$ & 30 & 18.4 & 11 & 0 & 0 & 0 & 0 & 1.2 & 0.367 & 0.32 \\
\hline $5 / 16$ & 30 & 17.5 & 6 & 1 & 0 & 0 & 0 & 1.5 & 0.233 & 0.32 \\
\hline $5 / 23$ & 40 & 17.5 & 15 & 0 & 0 & 0 & 0 & 4.3 & 0.375 & 0.32 \\
\hline $5 / 26$ & 45 & 18.3 & 17 & 0 & 0 & 0 & 0 & 3.1 & 0.378 & 0.32 \\
\hline & & & & & & & $M$ & pooled & 0.258 & $0.109)$ \\
\hline
\end{tabular}

Natural

$\begin{array}{lcccccccccc}3 / 17 & 60 & 12.6 & 11 & 1 & 0 & 0 & 0 & 1.4 & 0.2 & 0.172 \\ 3 / 20 & 79 & 11.6 & 28 & 0 & 0 & 0 & 0 & 5.2 & 0.354 & 0.172 \\ 3 / 23 & 31 & 12.4 & 1 & 0 & 0 & 0 & 0 & -- & 0.032 & 0.172 \\ 3 / 26 & 68 & 7.9 & 0 & 0 & 0 & 0 & 0 & -- & 0.0 & 0.172 \\ 4 / 5 & 61 & 11.9 & 13 & 3 & 0 & 0 & 0 & 6.6 & 0.262 & 0.2 \\ 4 / 10 & 24 & -- & 1 & 0 & 0 & 0 & 0 & 19.5 & 0.042 & 0.2 \\ 4 / 22 & 29 & 15.0 & 17 & 1 & 0 & 0 & 0 & 0.7 & 0.621 & 0.479 \\ 4 / 25 & 27 & 12.2 & 10 & 1 & 0 & 0 & 0 & 3.3 & 0.407 & 0.479 \\ 4 / 27 & 32 & 15.2 & 13 & 0 & 0 & 0 & 0 & 4.0 & 0.406 & 0.479 \\ 5 / 2 & 33 & 15.5 & 16 & 0 & 0 & 0 & 0 & 4.9 & 0.485 & 0.479 \\ 5 / 20 & 13 & 17.5 & 12 & 0 & 0 & 0 & 0 & 7.9 & 0.923 & 0.923\end{array}$

Mean pooled $T E=0.357(S D=0.227)$

Summer Steelhead

$\begin{array}{lcccccccccc}4 / 5 & 43 & 11.9 & 15 & 1 & 0 & 0 & 0 & 9.7 & 0.372 & 0.326 \\ 4 / 10 & 38 & -- & 7 & 1 & 0 & 0 & 0 & 32.9 & 0.211 & 0.326 \\ 4 / 29 & 21 & 17.0 & 11 & 0 & 0 & 1 & 0 & 0.9 & 0.571 & 0.326 \\ 5 / 17 & 47 & 18.4 & 17 & 0 & 0 & 0 & 0 & 4.2 & 0.362 & 0.326 \\ 5 / 20 & 35 & 17.5 & 7 & 0 & 0 & 0 & 0 & 3.8 & 0.2 & 0.326 \\ 5 / 23 & 29 & 17.5 & 12 & 0 & 0 & 0 & 0 & 6.2 & 0.414 & 0.326 \\ 5 / 25 & 23 & 18.2 & 5 & 0 & 0 & 0 & 0 & 5.5 & 0.217 & 0.326 \\ 5 / 31 & 35 & 19.5 & 6 & 0 & 0 & 0 & 0 & 5.6 & 0.171 & 0.171\end{array}$

Mean pooled $T E=0.307(S D=0.051)$ 
Table 16. Smolt-yield-per-spawner of naturally produced spring chinook salmon, fall chinook salmon and summer steelhead, Umatilla River 2002.

\begin{tabular}{|c|c|c|c|c|c|c|c|c|}
\hline Species $^{a}$ & $\begin{array}{c}\text { Return } \\
\text { Year }\end{array}$ & $\begin{array}{c}\text { Pre- } \\
\text { dominant } \\
\text { smolt } \\
\text { outmigration } \\
\text { year } \\
\end{array}$ & $\begin{array}{c}\text { No. of } \\
\text { adult } \\
\text { males } \\
\text { available } \\
\text { to spawn }\end{array}$ & $\begin{array}{c}\text { No. of } \\
\text { adult } \\
\text { females } \\
\text { available } \\
\text { to spawn }\end{array}$ & $\begin{array}{l}\text { Spawning }^{d} \\
\text { escapement }\end{array}$ & $\begin{array}{c}\text { No. } \\
\text { spawners }\end{array}$ & $\begin{array}{l}\text { No. }^{e} \\
\text { smolts }\end{array}$ & $\begin{array}{l}\text { Smolt } \\
\text { yield } \\
\text { per } \\
\text { spawner }\end{array}$ \\
\hline NCHS & 00 & 02 & $\mathrm{ND}^{c}$ & $\mathrm{ND}^{c}$ & 2,724 & 1,442 & 36,242 & 25.1 \\
\hline $\mathrm{NCHF}$ & 01 & 02 & 881 & 519 & 1,400 & 1,038 & $8,084^{f}$ & 7.8 \\
\hline $\mathrm{NSTS}^{b}$ & 00 & 02 & 1,001 & 1,618 & 2,619 & 2,619 & 77,016 & 29.4 \\
\hline
\end{tabular}

a $\quad N C H S=$ natural spring chinook salmon, $N C H F=$ natural fall chinook salmon, and NSTS =natural summer steelhead.

$b \quad$ Steelhead data presented is based on predominate smolt outmigration year (age $2+$ smolts).

c $N D=$ not determined.

$d \quad$ Spawning escapement $=$ total returns to Three Mile Fallls Dam plus outplants, less broodstock take and estimated pre-spawn mortality.

e Number of smolts estimated from outmigration monitoring at Three Mile Falls Dam (RM 3.7).

$f \quad$ Includes the months of June and July only, in order to stay consistent with methodologies outlined in Chess et al. 2003. 
Table 17. Summary of PIT-tagged hatchery subyearling fall chinook salmon released for trap and haul operations (transportation evaluation studies) in the lower Umatilla River, July 2002.

\begin{tabular}{|c|c|c|c|c|c|c|c|}
\hline $\begin{array}{l}\text { Release } \\
\text { group }\end{array}$ & $\begin{array}{c}\text { Release } \\
\text { date }\end{array}$ & $\begin{array}{l}\text { Holding }^{a} \\
\text { temperature }\end{array}$ & $\begin{array}{c}\text { Release }^{a} \\
\text { temperature }\end{array}$ & $\begin{array}{l}\text { River flow } \\
\left(\mathrm{ft}^{3} / \mathrm{s}\right)^{b}\end{array}$ & $\begin{array}{l}\text { Release } \\
\text { number }\end{array}$ & $\begin{array}{l}\text { Number }^{c} \\
\text { detected }\end{array}$ & $\begin{array}{c}\text { Percent } \\
\text { detection }\end{array}$ \\
\hline \multicolumn{8}{|c|}{ Treatment (Transported) } \\
\hline WT1 & $7 / 8 / 02$ & 23.0 & 19.0 & 30 & 206 & 36 & 17.5 \\
\hline WT2 & $7 / 10 / 02$ & 22.0 & 20.0 & 15 & 208 & 35 & 16.8 \\
\hline WT3 & $7 / 12 / 02$ & 26.0 & 20.0 & 17 & 278 & 5 & 1.8 \\
\hline $\mathrm{WT}^{d}$ & -- & -- & -- & -- & -- & -- & -- \\
\hline WT5 $^{d}$ & -- & -- & -- & -- & -- & -- & -- \\
\hline \multicolumn{8}{|c|}{ Control (Non-transported) } \\
\hline WC1 & $7 / 5 / 02$ & 19.0 & 18.0 & 95 & 298 & 2 & 0.7 \\
\hline WC2 & $7 / 6 / 02$ & 20.0 & 18.0 & 72 & 300 & 3 & 1.0 \\
\hline WC3 & $7 / 7 / 02$ & 22.0 & 18.0 & 46 & 276 & 2 & 0.7 \\
\hline WC4 & $7 / 8 / 02$ & 23.0 & 22.5 & 30 & 294 & 0 & 0.0 \\
\hline WC5 & $7 / 9 / 02$ & 22.0 & 20.0 & 17 & 298 & 0 & 0.0 \\
\hline
\end{tabular}

a Holding and release water temperatures presented in ${ }^{\circ} \mathrm{C}$.

b Flow data obtained from UMDO (RM 24.4).

$c \quad$ Number detected includes detections at mainstem Columbia River dams and mainstem island recoveries.

d Tests dropped due to unfavorable holding conditions. 
Table 18. Correlation of daily fish passage index with river discharge and water temperature, Umatilla River, October 2001 - September 2002.

\begin{tabular}{|c|c|c|c|c|c|c|}
\hline \multirow[b]{2}{*}{ Species } & \multicolumn{3}{|c|}{ Discharge } & \multicolumn{3}{|c|}{ Temperature } \\
\hline & $N^{a}$ & $r^{b}$ & $P_{.05}{ }^{c}$ & $N^{a}$ & $r^{b}$ & $P_{.05}{ }^{c}$ \\
\hline & & & Hatche & & & \\
\hline CHS & 131 & 0.480 & 0.000 & 131 & -0.412 & 0.000 \\
\hline $\mathrm{CHF}$ & 70 & 0.224 & 0.062 & 70 & -0.171 & 0.156 \\
\hline CHF0 & 52 & 0.277 & 0.047 & 52 & -0.139 & 0.324 \\
\hline $\mathrm{COH}$ & 81 & 0.283 & 0.011 & 81 & -0.030 & 0.787 \\
\hline STS & 131 & 0.119 & 0.176 & 131 & 0.183 & 0.037 \\
\hline & & & Natur & & & \\
\hline CHS & 149 & 0.359 & 0.000 & 149 & 0.083 & 0.315 \\
\hline $\mathrm{CHO}$ & 131 & 0.066 & 0.456 & 131 & 0.436 & 0.000 \\
\hline $\mathrm{COH}$ & 273 & 0.018 & 0.763 & 273 & 0.312 & 0.000 \\
\hline STS & 158 & 0.416 & 0.000 & 158 & 0.314 & 0.000 \\
\hline & & & Unkno & & & \\
\hline $\mathrm{COH}$ & 123 & 0.608 & 0.000 & 123 & -0.539 & 0.000 \\
\hline
\end{tabular}

a $\quad N=$ number of observations.

${ }^{b} \quad r=$ correlation coefficient.

c Probability (t-test) that the correlation coefficient is no different from zero; significant $P \leq 0.05$. 
Table 19. Percent passage index for natural spring chinook salmon (NCHS), subyearling chinook salmon (NCH0), coho salmon $(\mathrm{NCOH})$, and summer steelhead (NSTS) observed within given environmental categories. * represents significance $(P \leq 0.05)$.

Environmental Range
Change in Discharge

$\begin{array}{lcccc}>-10 \% & 32(22)^{b} & 15(10) & 20(17) & 29(20) \\ >-1 \text { to }<-10 \% & 21(33) & 25(35) & 23(35) & 32(35) \\ 1 \% & 19(9) & 33(30) & 22(18) & 16(12) \\ >1 \text { to }<10 \% & 10(16) & 27(21) & 30(18) & 16(18) \\ >10 \% & 18(20) & 0(4) & 5(12) & 7(15) \\ & & & & 10.4^{*}\end{array}$

Water Temperature

$\begin{array}{lcccc}<10.0{ }^{\circ} \mathrm{C} & 61(66) & 1(40) & 14(55) & 26(53) \\ 10.0 \text { to }<12.5{ }^{\circ} \mathrm{C} & 33(15) & 3(11) & 4(14) & 43(14) \\ 12.5 \text { to }<15.0^{\circ} \mathrm{C} & 3(9) & 1(12) & 1(10) & 8(9) \\ 15.0 \text { to }<17.5{ }^{\circ} \mathrm{C} & 2(9) & 4(8) & 11(7) & 13(11) \\ 17.5 \text { to }<20{ }^{\circ} \mathrm{C} & 1(1) & 28(11) & 31(6) & 8(7) \\ >20{ }^{\circ} \mathrm{C} & 0(0) & 63(18) & 39(80) & 2(6)\end{array}$

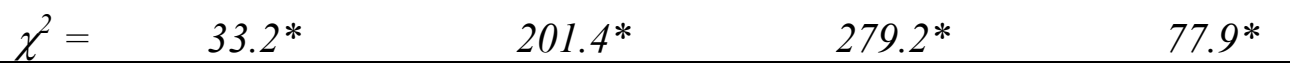

a $\quad$ NCHS = natural spring chinook salmon, $\mathrm{NCHO}=$ natural subyearling fall chinook salmon, $N C O H=$ natural coho salmon, NSTS = natural summer steelhead.

${ }^{b} \quad$ Number in parentheses is the percentage of the emigration season within each environmental range. 
Table 20. Summary of linear regression analysis for trapping efficiency as a function of multiple environmental and operational variables.

\begin{tabular}{|c|c|c|c|c|c|c|c|c|c|}
\hline \multirow{2}{*}{ Species } & \multicolumn{3}{|c|}{ Discharge } & \multicolumn{3}{|c|}{ Canal Diversion } & \multicolumn{3}{|c|}{ Temperature } \\
\hline & $N^{a}$ & $r^{2 b}$ & $P .05^{c}$ & $N^{a}$ & $r^{2 b}$ & $P .05^{c}$ & $N^{a}$ & $r^{2 b}$ & $P .05^{c}$ \\
\hline \multicolumn{10}{|c|}{ Hatchery } \\
\hline CHS & 18 & 0.244 & 0.037 & 18 & 0.557 & 0.000 & 18 & 0.421 & 0.004 \\
\hline CHF & 15 & 0.386 & 0.013 & 15 & 0.248 & 0.059 & 15 & 0.087 & 0.286 \\
\hline CHF0 & 16 & 0.038 & 0.470 & 16 & 0.223 & 0.065 & 16 & 0.318 & 0.023 \\
\hline STS & 16 & 0.034 & 0.493 & 16 & 0.085 & 0.274 & 16 & 0.312 & 0.025 \\
\hline \multicolumn{10}{|c|}{ Natural } \\
\hline $\mathrm{CH}^{d}$ & 13 & 0.039 & 0.519 & 13 & 0.696 & 0.000 & 13 & 0.006 & 0.800 \\
\hline STS & 8 & 0.017 & 0.760 & 8 & 0.025 & 0.708 & 8 & 0.050 & 0.597 \\
\hline \multicolumn{10}{|c|}{ Unknown } \\
\hline $\mathrm{COH}$ & 18 & 0.326 & 0.013 & 18 & 0.363 & 0.008 & 18 & 0.386 & 0.006 \\
\hline
\end{tabular}

a $\quad N=$ number of observations.

${ }^{b} r^{2}=$ regression coefficient.

$c$ Probability (t-test) that the regression coefficient is no different from zero; significant $P \leq 0.05$.

$d \quad$ Natural chinook salmon trap efficiency releases include yearling and subyearling age classes. 
Table 21. Summary of Pacific lamprey captured at RM 1.2 and RM 3.7, $1995-2002$.

\begin{tabular}{lccccc}
\hline Year & Adult & Macrophothalmia & Larvae & $\begin{array}{c}\text { Unknown } \\
\text { juvenile }\end{array}$ & Total \\
\hline & & & & & \\
1995 & 17 & 0 & 0 & 24 & 41 \\
1996 & 12 & 0 & 0 & 214 & 226 \\
1997 & 8 & 0 & 0 & 297 & 305 \\
1998 & 1 & 103 & 465 & 0 & 569 \\
1999 & 0 & 76 & 197 & 1 & 274 \\
2000 & 1 & 133 & 363 & 0 & 497 \\
2001 & 1 & 1,988 & 755 & 0 & 2,744 \\
2002 & 2 & 25 & 83 & 0 & 110 \\
\hline
\end{tabular}

Table 22. Number of resident species captured at RM 1.2 and RM 3.7 and fork length summary statistics, Umatilla River, October 2001 - September 2002.

\begin{tabular}{lcccc}
\hline & & \multicolumn{3}{c}{ Fork Length } \\
\cline { 3 - 5 } Common Name & Number Captured & $\mathrm{N}$ & Mean & Range \\
\hline & & & & \\
Bass & 503 & 388 & 160.4 & $24-267$ \\
Bluegill & 124 & 56 & 87.6 & $30-158$ \\
Bullhead & 71 & 35 & 139.3 & $48-289$ \\
Carp & 18 & 15 & 101.1 & $50-146$ \\
Chiselmouth & 3,948 & 867 & 171.8 & $52-294$ \\
Crappie & 205 & 194 & 44.9 & $22-188$ \\
Dace & 9 & 7 & 60.9 & $43-106$ \\
Mosquitofish & 2 & 1 & 19.0 & -- \\
Mountain whitefish & 1 & -- & -- & -- \\
Northern pikeminnow & 380 & 128 & 179.2 & $55-380$ \\
Peamouth & 2 & 2 & 80.5 & $71-90$ \\
Pumpkinseed & 13 & 10 & 103.2 & $94-120$ \\
Redside shiner & 39 & 27 & 74.2 & $42-103$ \\
Sucker & 2,221 & 937 & 180.6 & $22-380$ \\
& & & & \\
Total & 7,536 & -- & -- & - \\
\hline
\end{tabular}




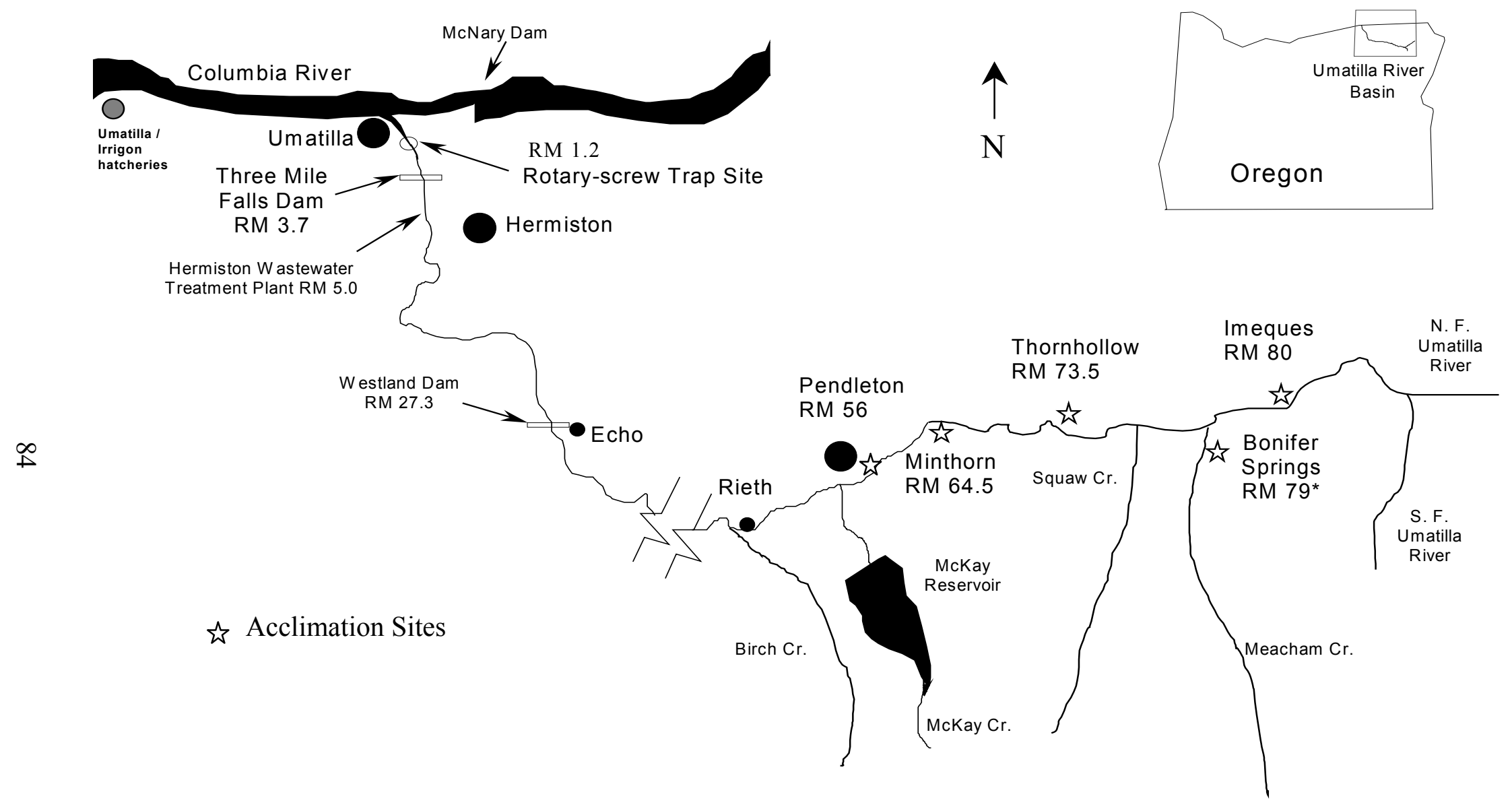

Figure 1. Detailed study area map and release locations, Umatilla River, 2002. 


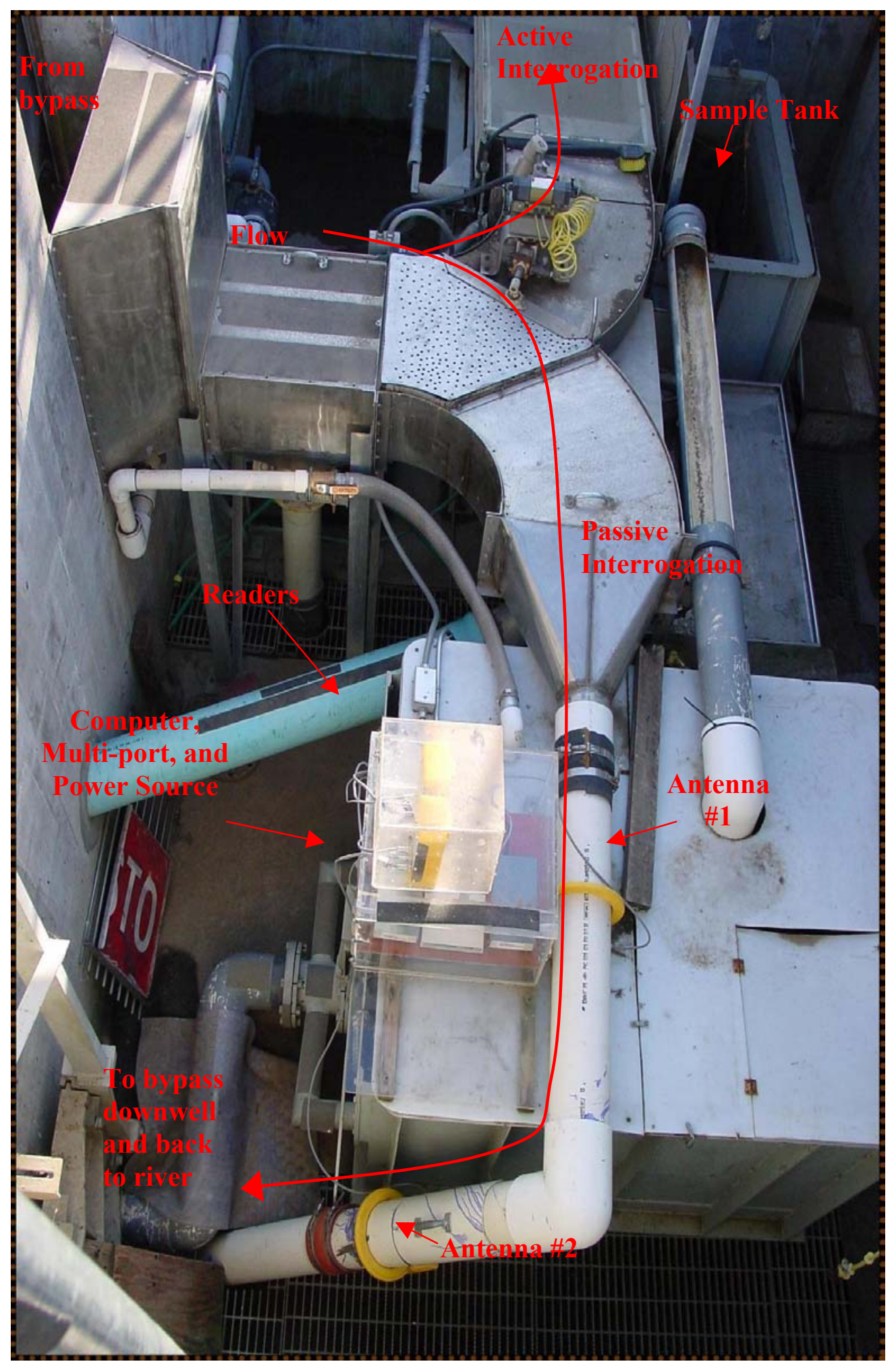

Figure 2. Remote PIT-tag interrogation system (134 kHz) used at West Extension Canal (RM 3.7), Umatilla River, 2002. 


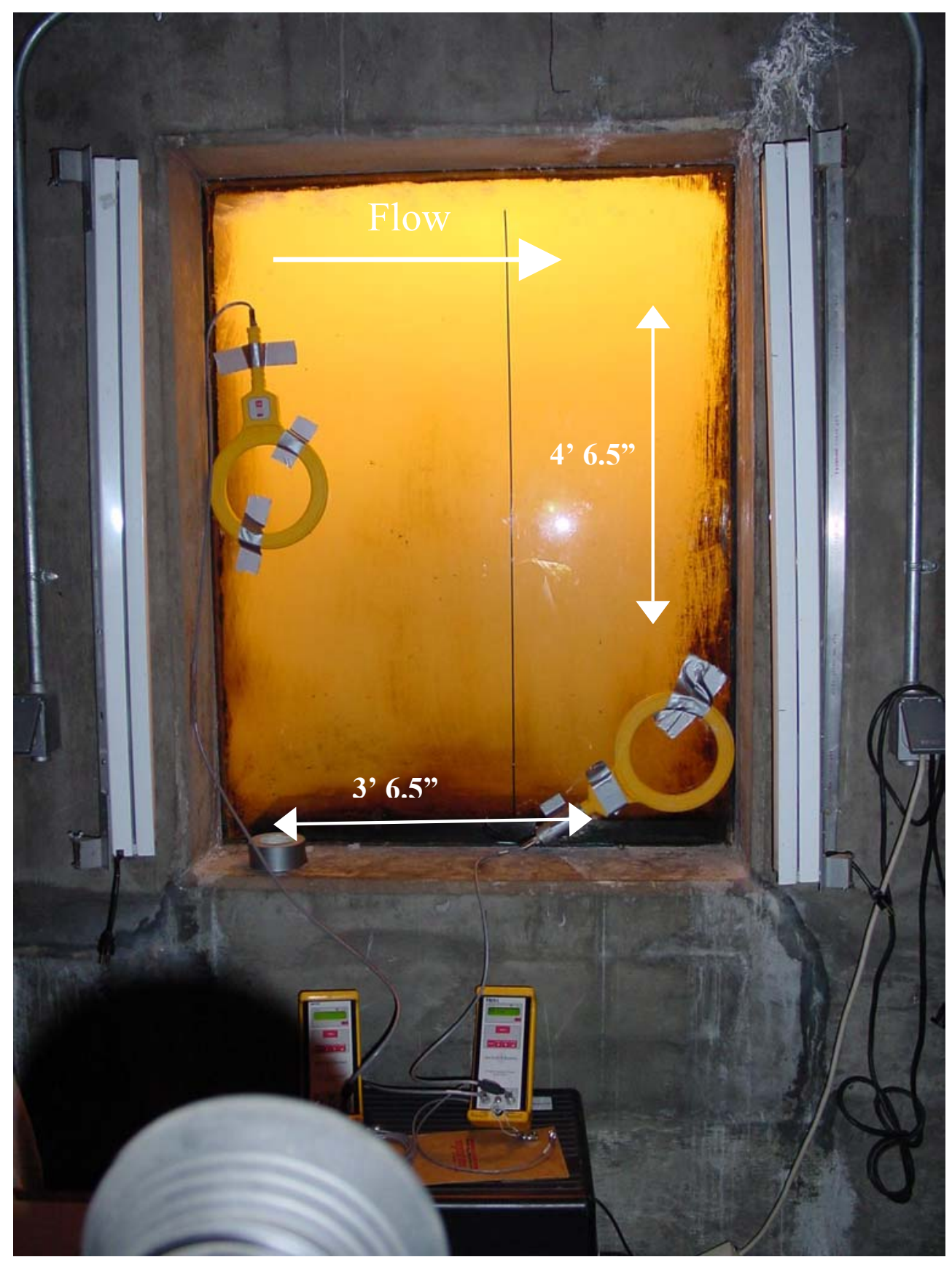

Figure 3. Temporary set up of portable detection system at east-bank viewing window, Three Mile Falls Dam (RM 3.7), Umatilla River, 2002. 


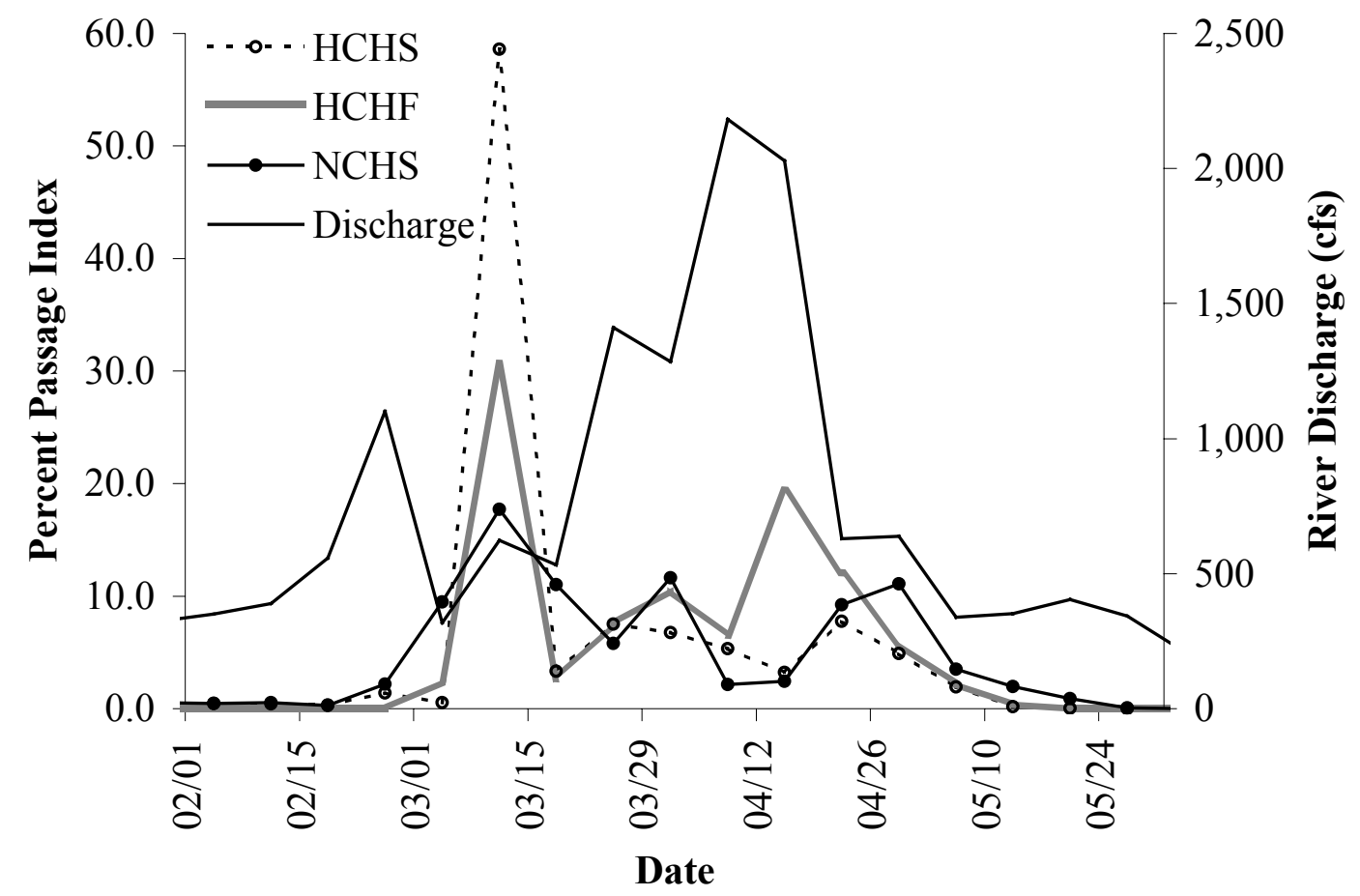

Figure 4. Passage timing of hatchery yearling spring (HCHS) and fall chinook (HCHF) and natural spring chinook salmon (NCHS) versus river discharge (cfs), RM 1.2 and 3.7, Umatilla River, 2002.

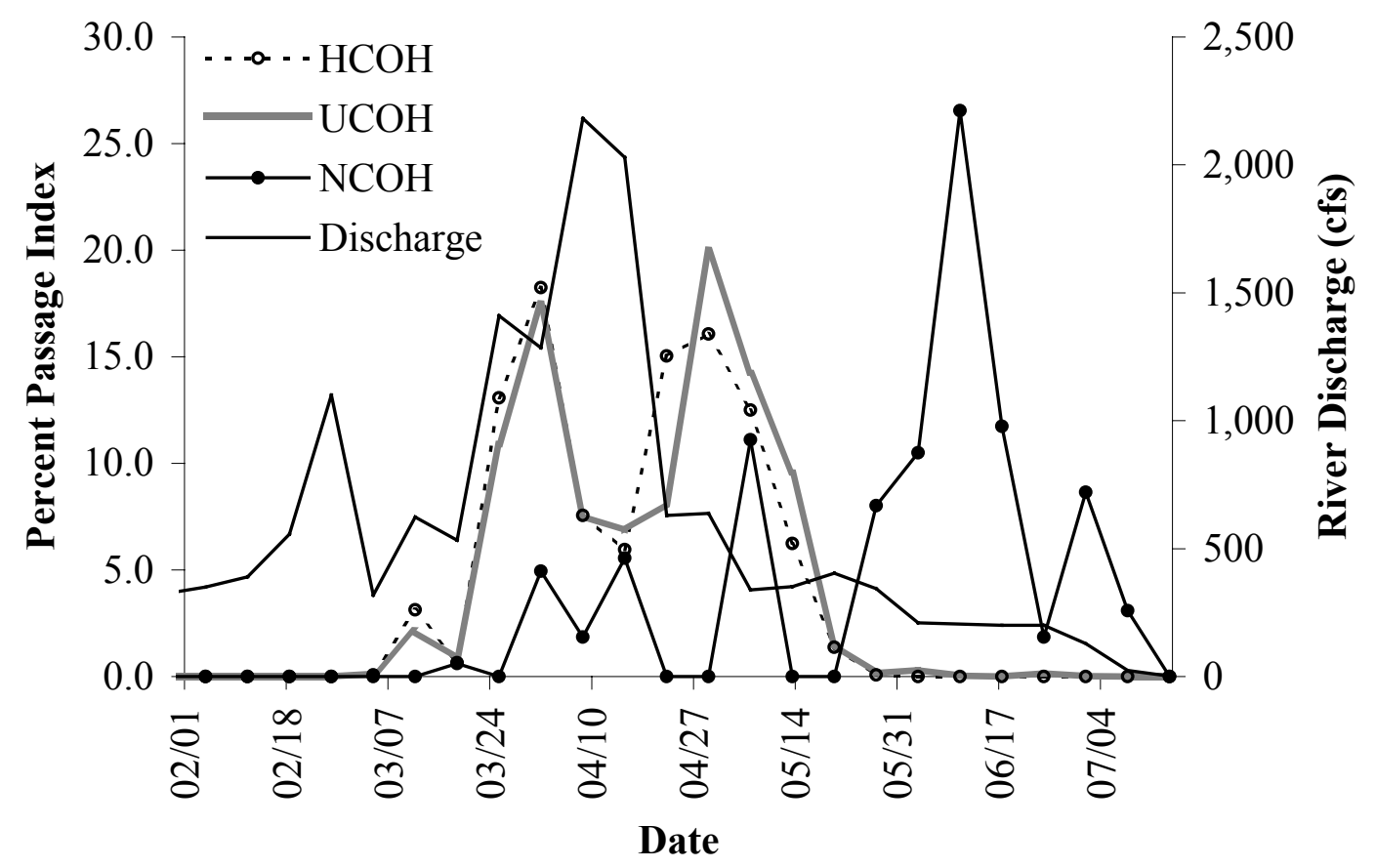

Figure 5. Passage timing of hatchery $(\mathrm{HCOH})$, unknown origin $(\mathrm{UCOH})$, and natural coho salmon $(\mathrm{NCOH})$ versus river discharge (cfs), RM 1.2 and 3.7, Umatilla River, 2002. 


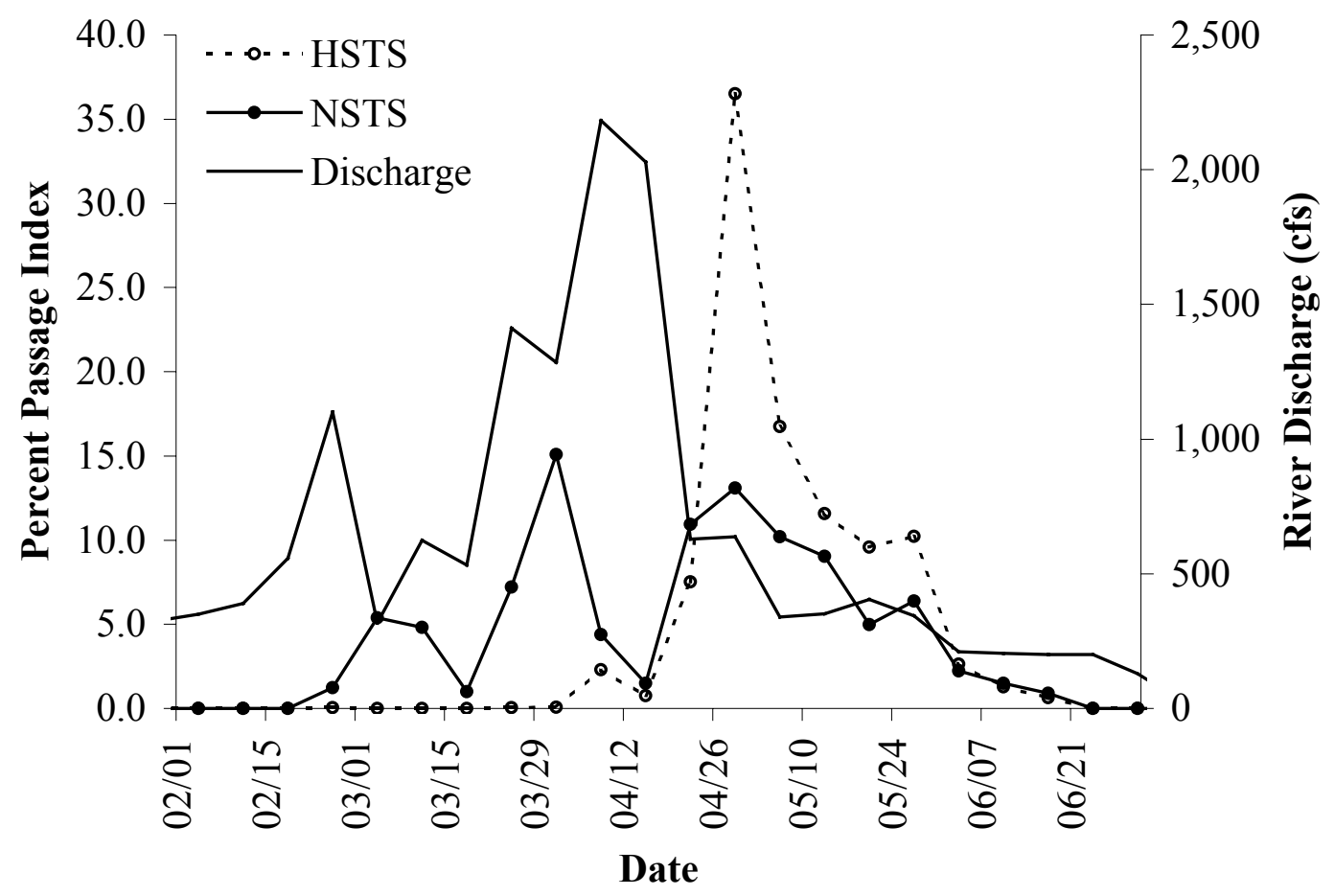

Figure 6. Passage timing of hatchery (HSTS) and natural steelhead (NSTS) versus river discharge (cfs), RM 1.2 and 3.7, Umatilla River, 2002.

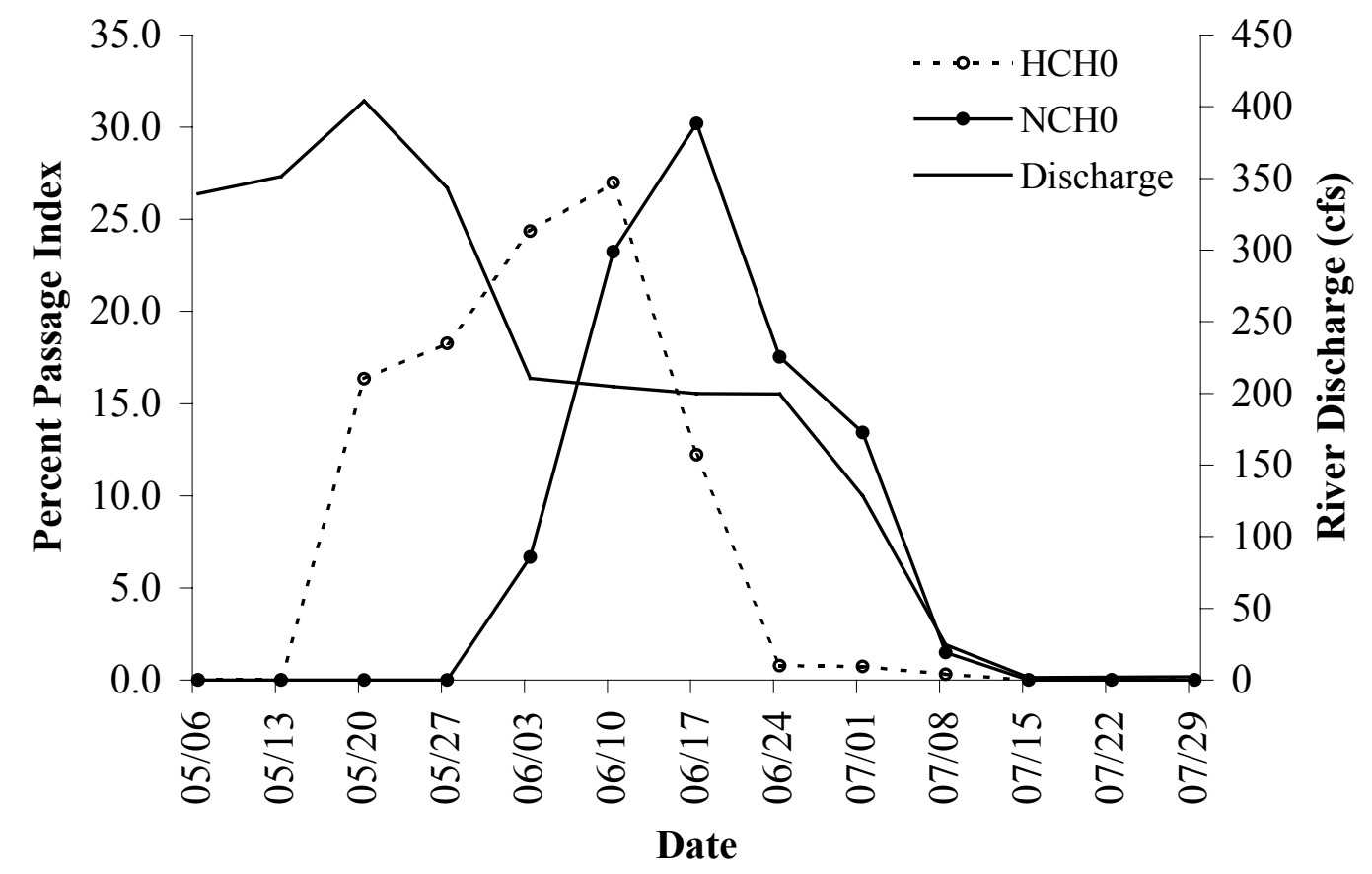

Figure 7. Passage timing of hatchery $(\mathrm{HCH} 0)$ and natural subyearling chinook salmon $(\mathrm{NCH} 0)$ versus river discharge (cfs), RM 1.2 and 3.7, Umatilla River, 2002. 


\section{Hatchery Spring Chinook Salmon}

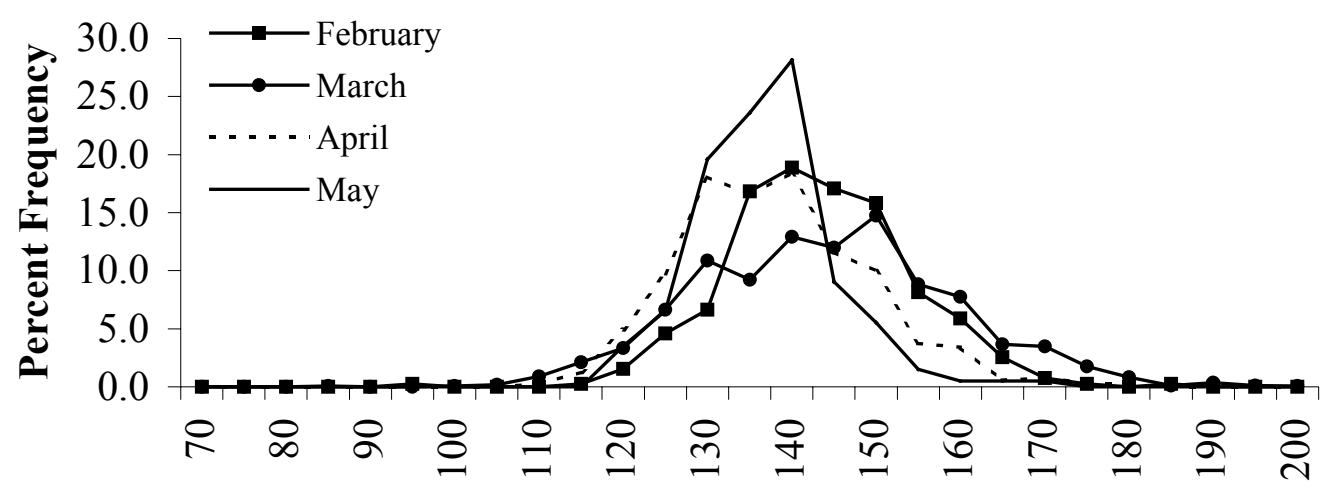

\section{Natural Spring Chinook Salmon}

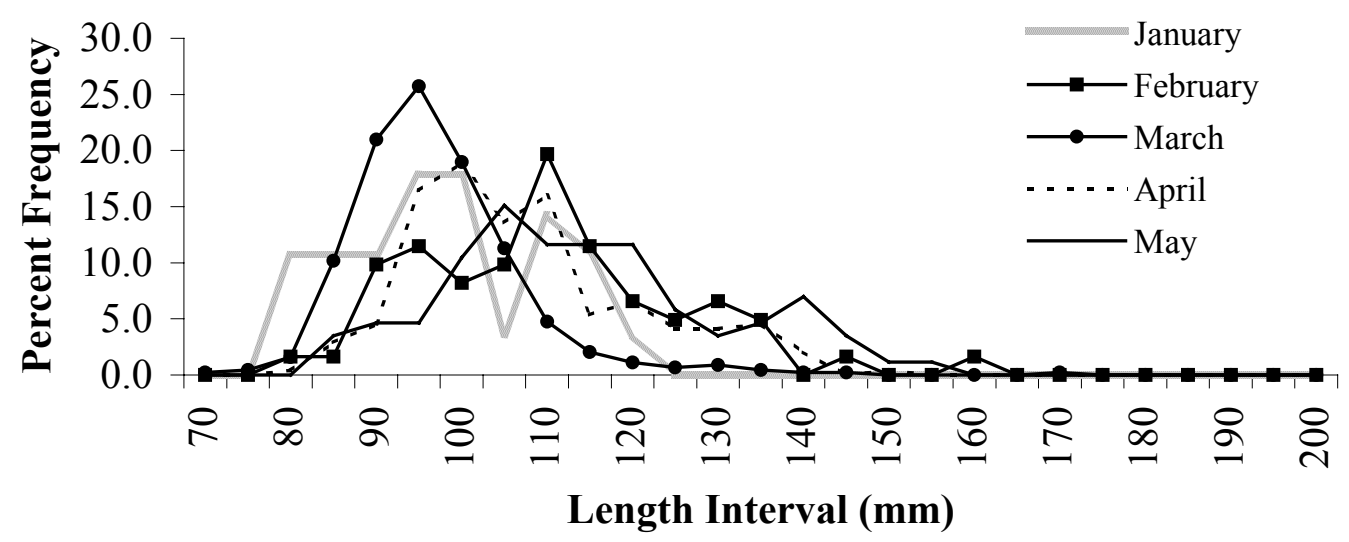

\section{Hatchery Fall Chinook Salmon}

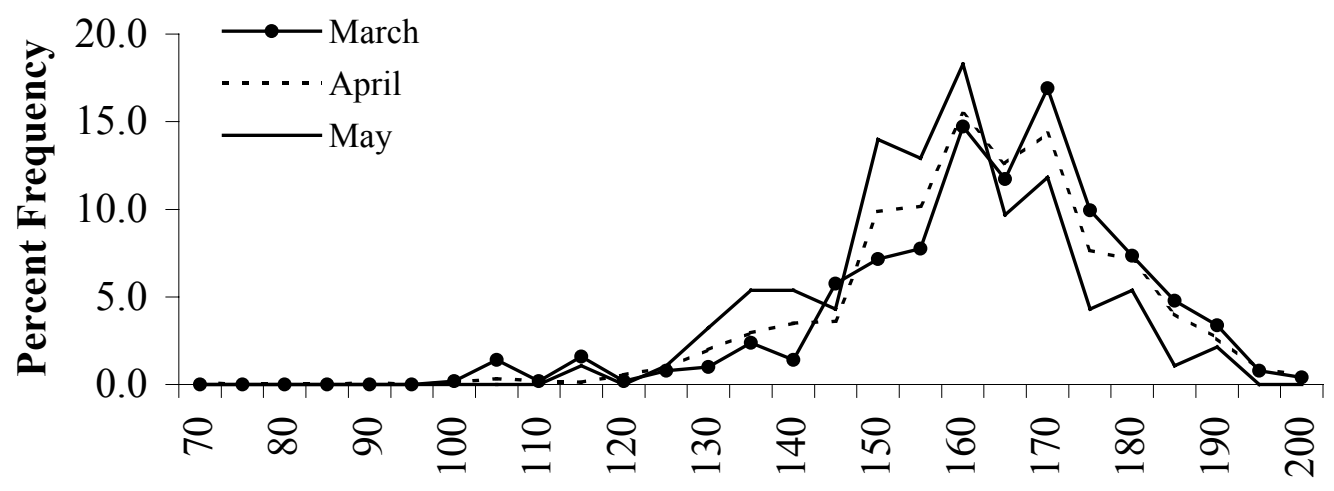

Figure 8. Length-frequency distribution of yearling spring and fall chinook salmon captured at RM 1.2 and RM 3.7, Umatilla River, January - May 2002. 


\section{Hatchery Coho Salmon}

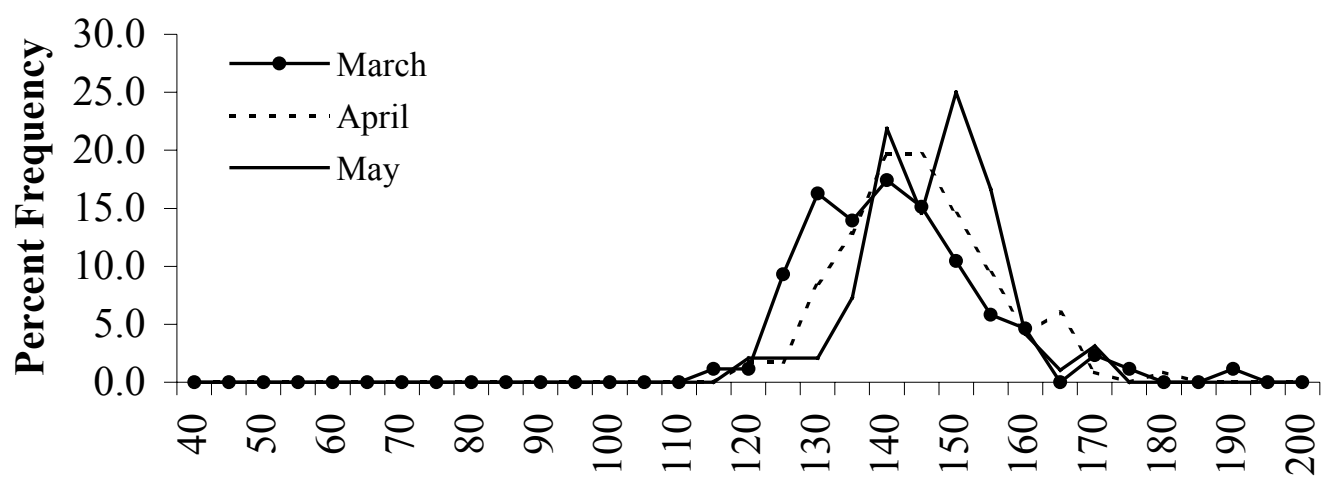

\section{Unknown Coho Salmon}

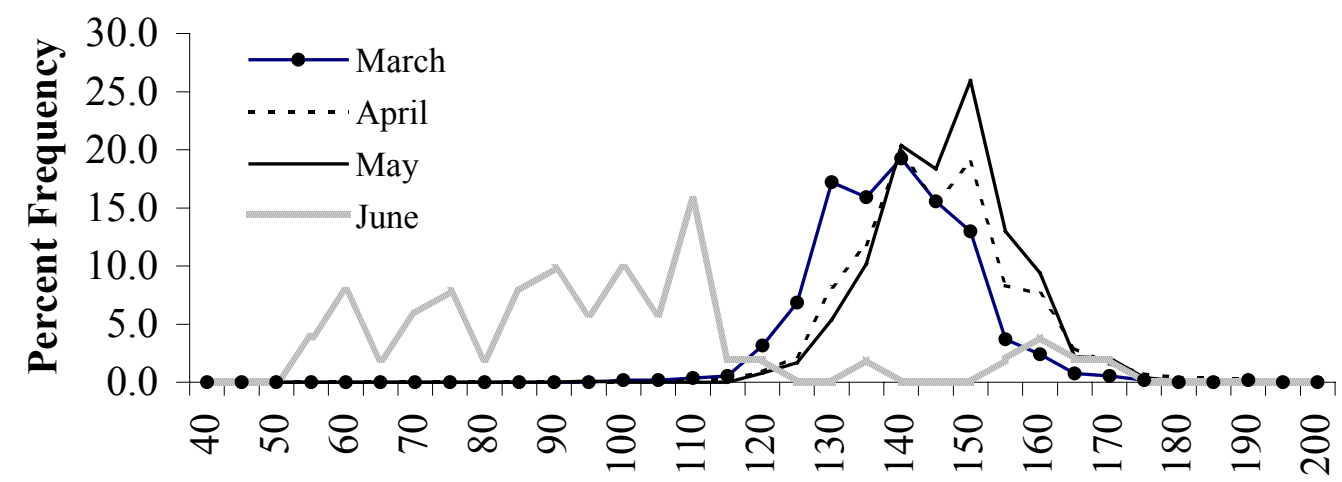

Natural Coho Salmon

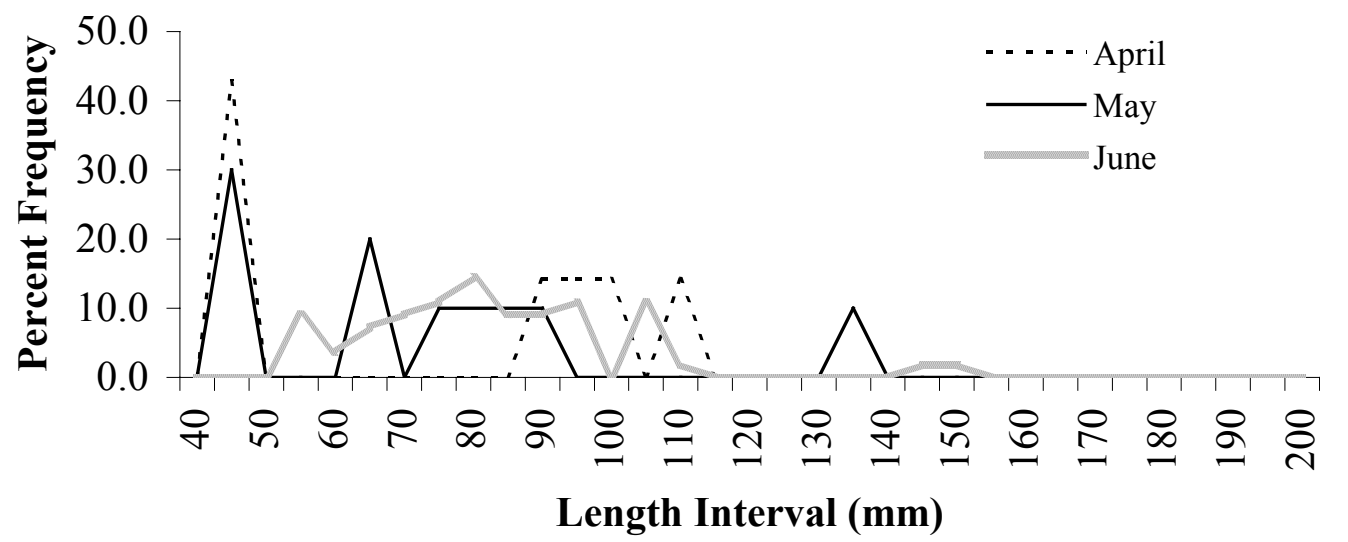

Figure 9. Length-frequency distribution of coho salmon captured at RM 1.2 and RM 3.7, Umatilla River, March - June 2002. 


\section{Hatchery Fall Chinook Salmon}

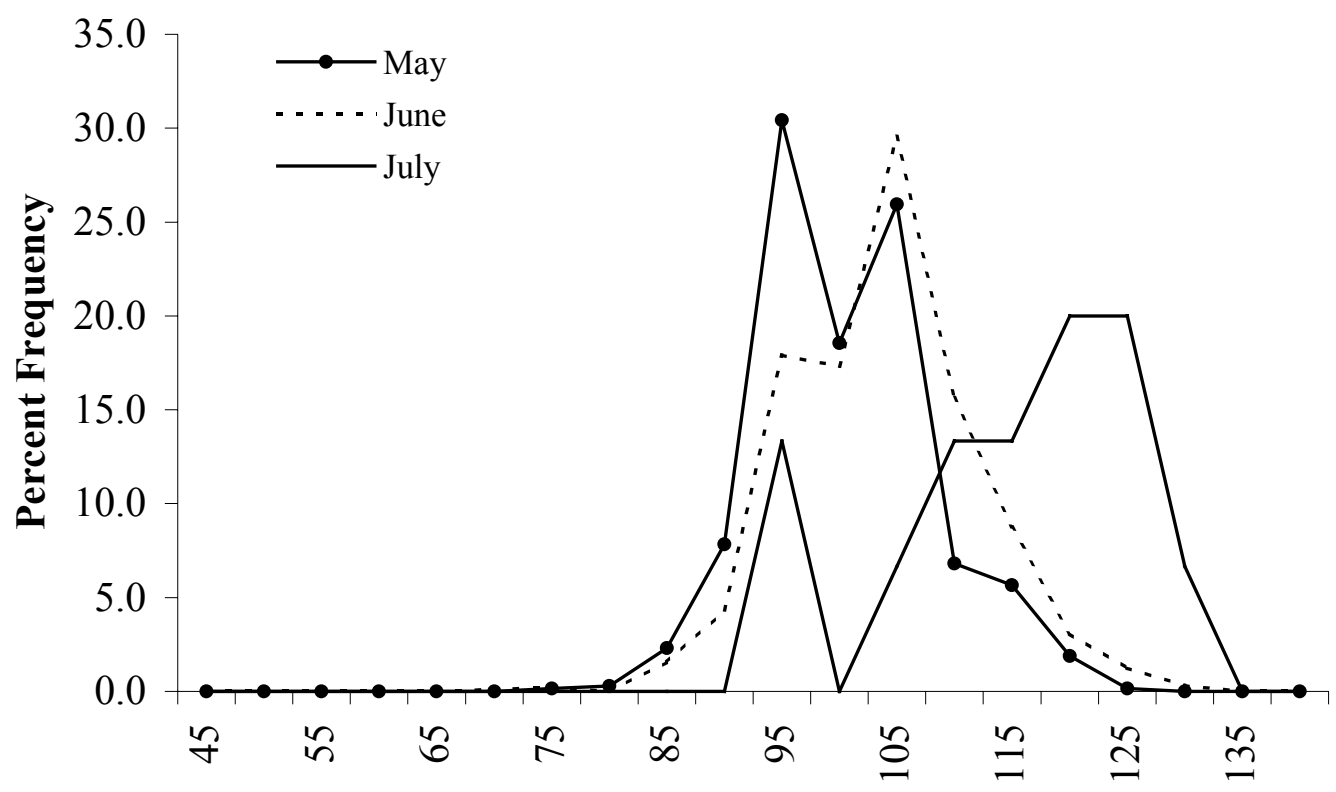

\section{Natural Chinook Salmon}

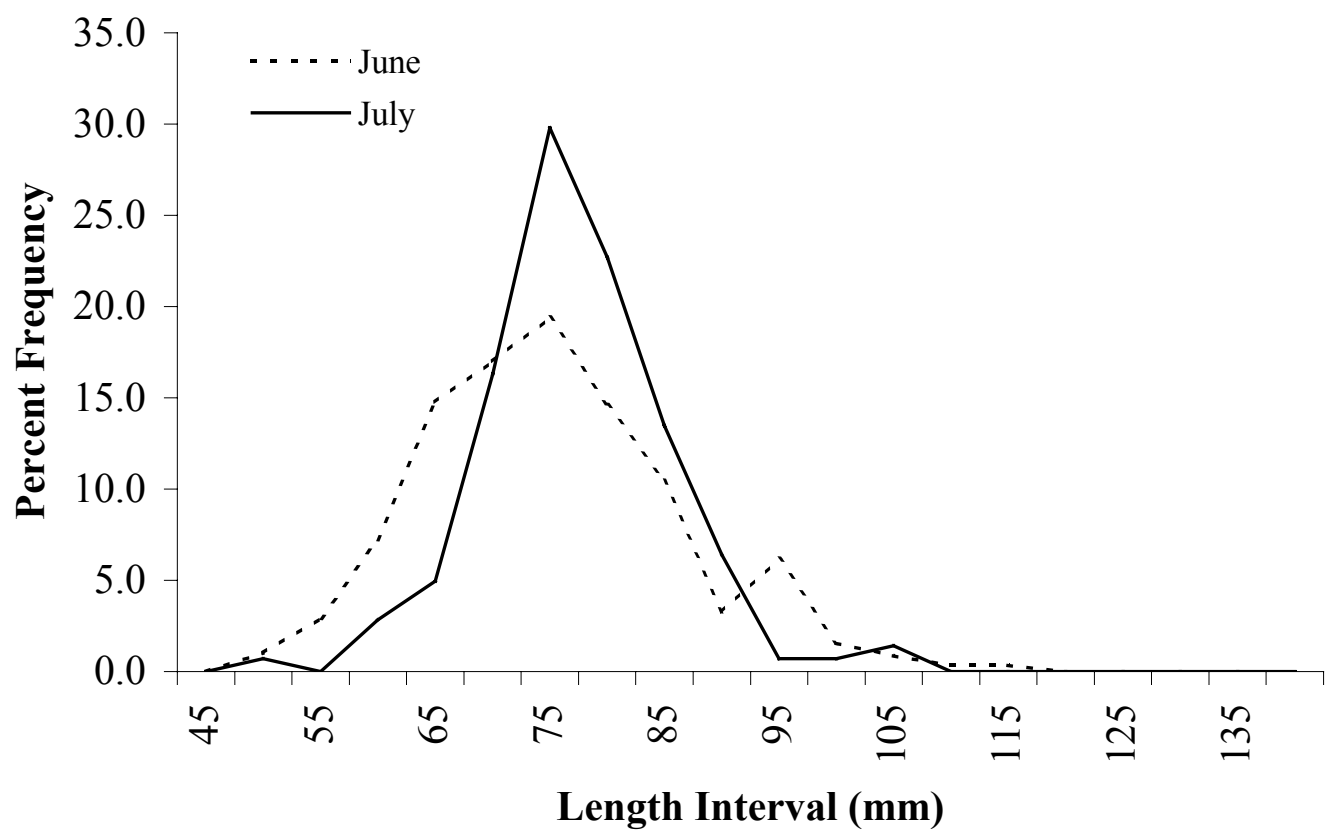

Figure 10. Length-frequency distribution of subyearling chinook salmon captured at RM 1.2 and RM 3.7, Umatilla River, May - July 2002. 


\section{Hatchery Summer Steelhead}

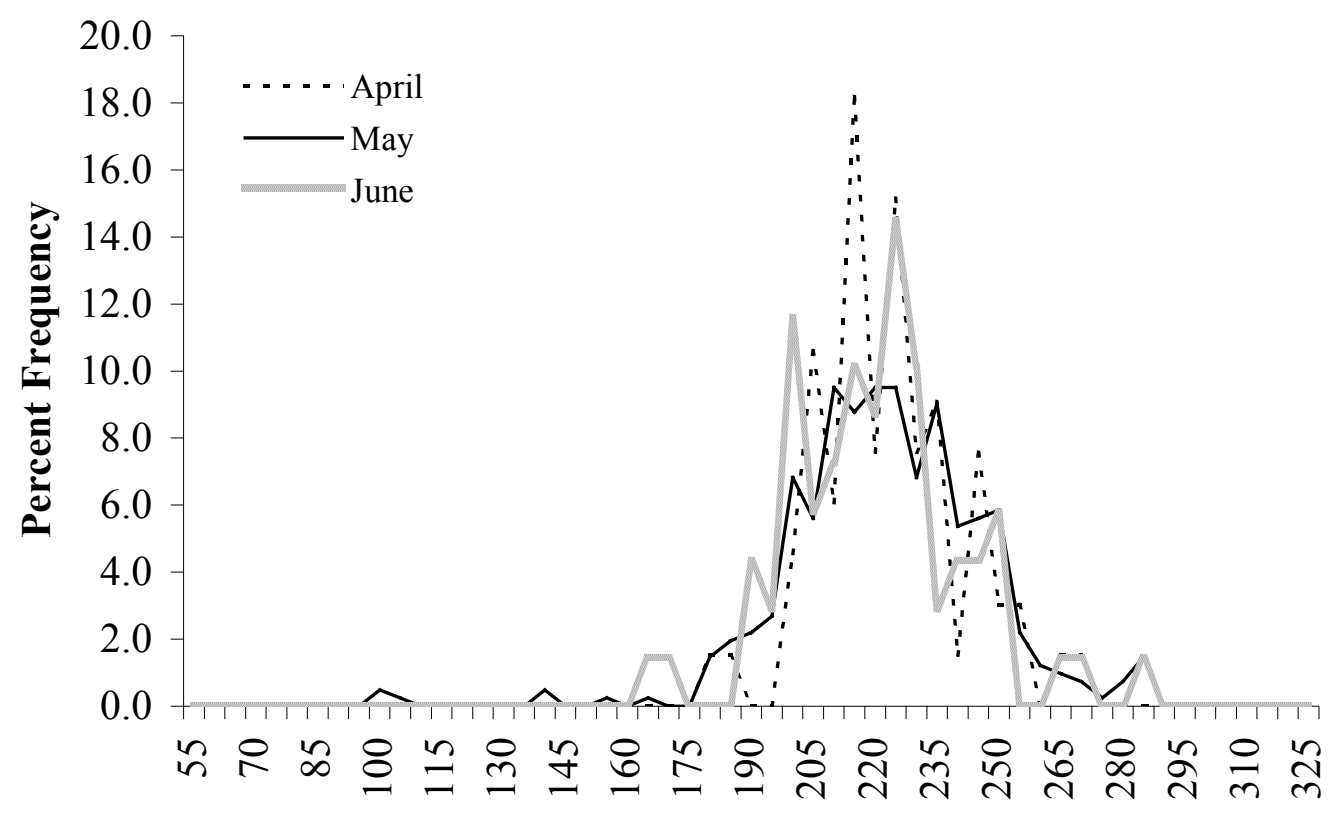

\section{Natural Summer Steelhead}

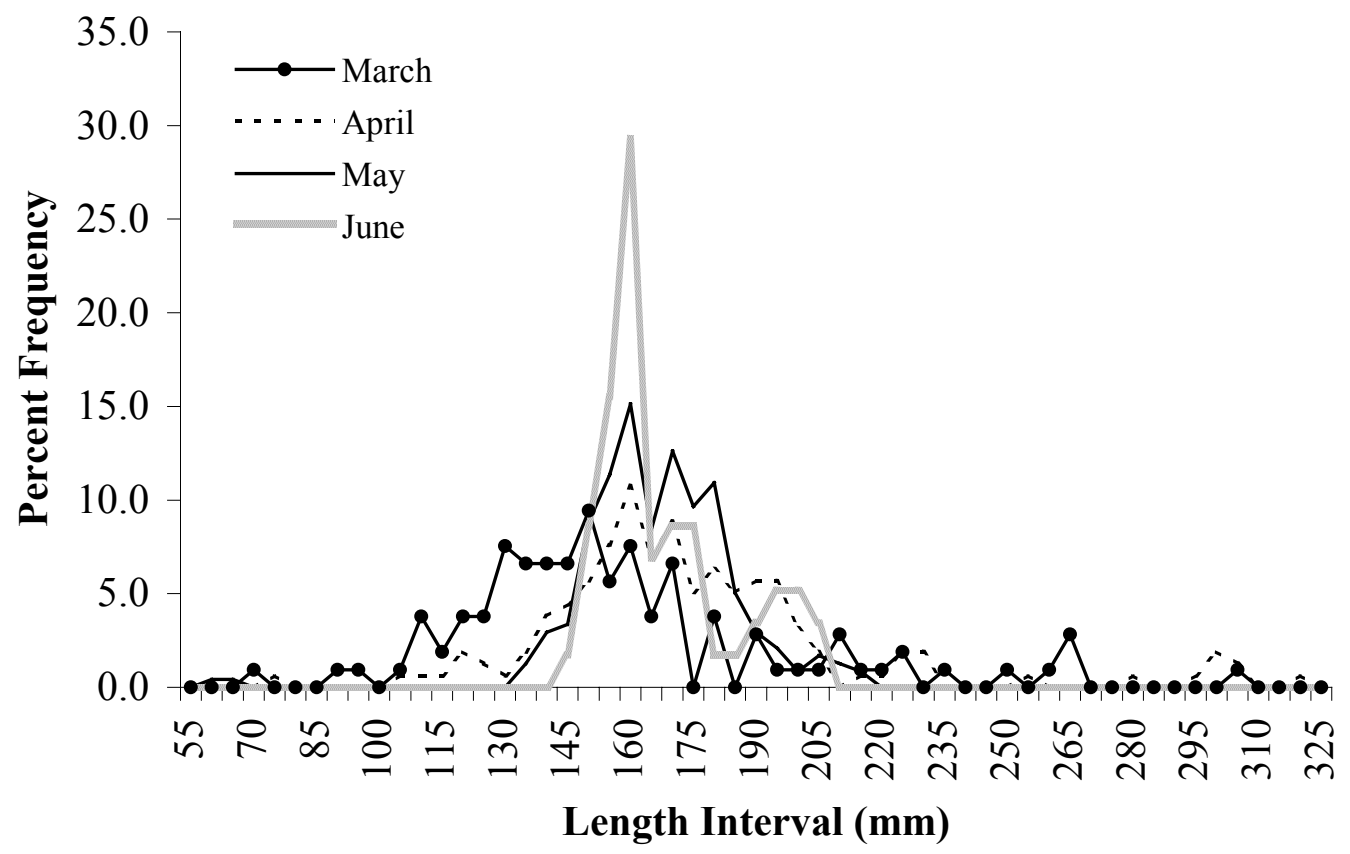

Figure 11. Length-frequency distribution of summer steelhead captured at RM 1.2 and RM 3.7, Umatilla River, March - June 2002. 


\section{Spring Chinook Salmon}

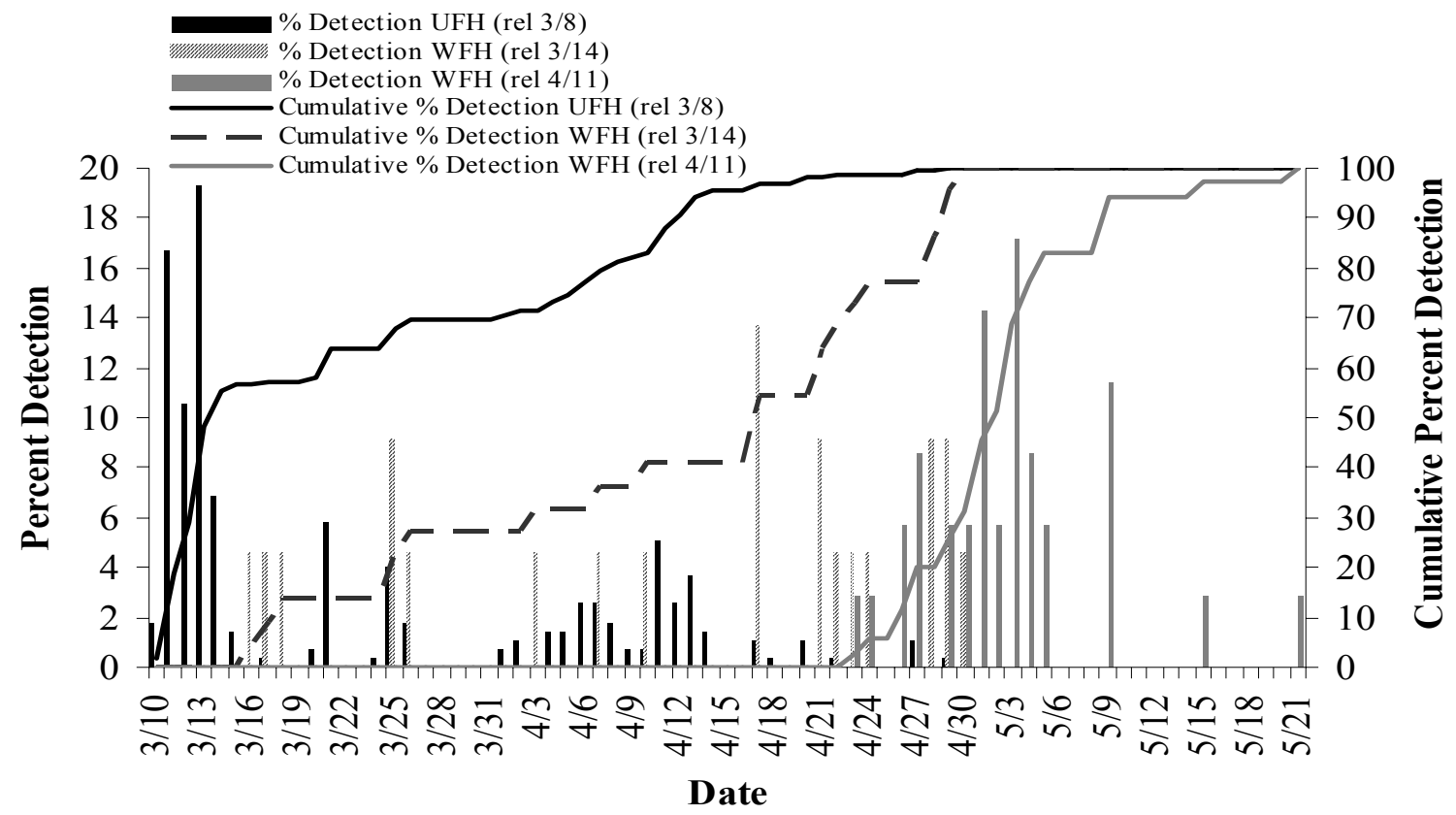

\section{Fall Chinook Salmon}

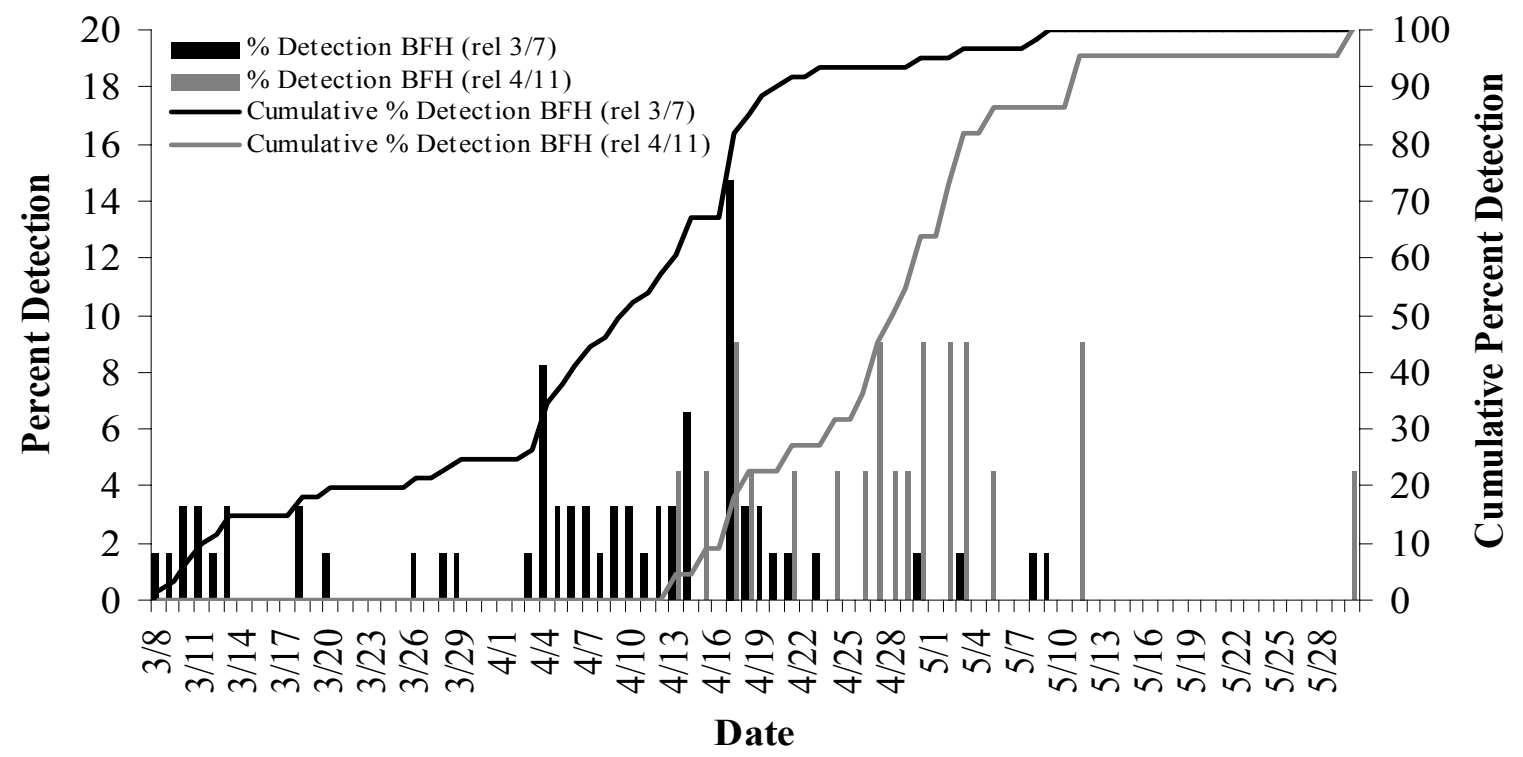

Figure 12. Percent and cumulative percent detection at RM 3.7 of PIT-tagged hatchery spring and fall chinook salmon from Umatilla Fish Hatchery (UFH), Willard National Fish Hatchery (WFH), and Bonneville Fish Hatchery (BFH), Umatilla River, March - May 2002. 


\section{Spring Chinook Salmon}

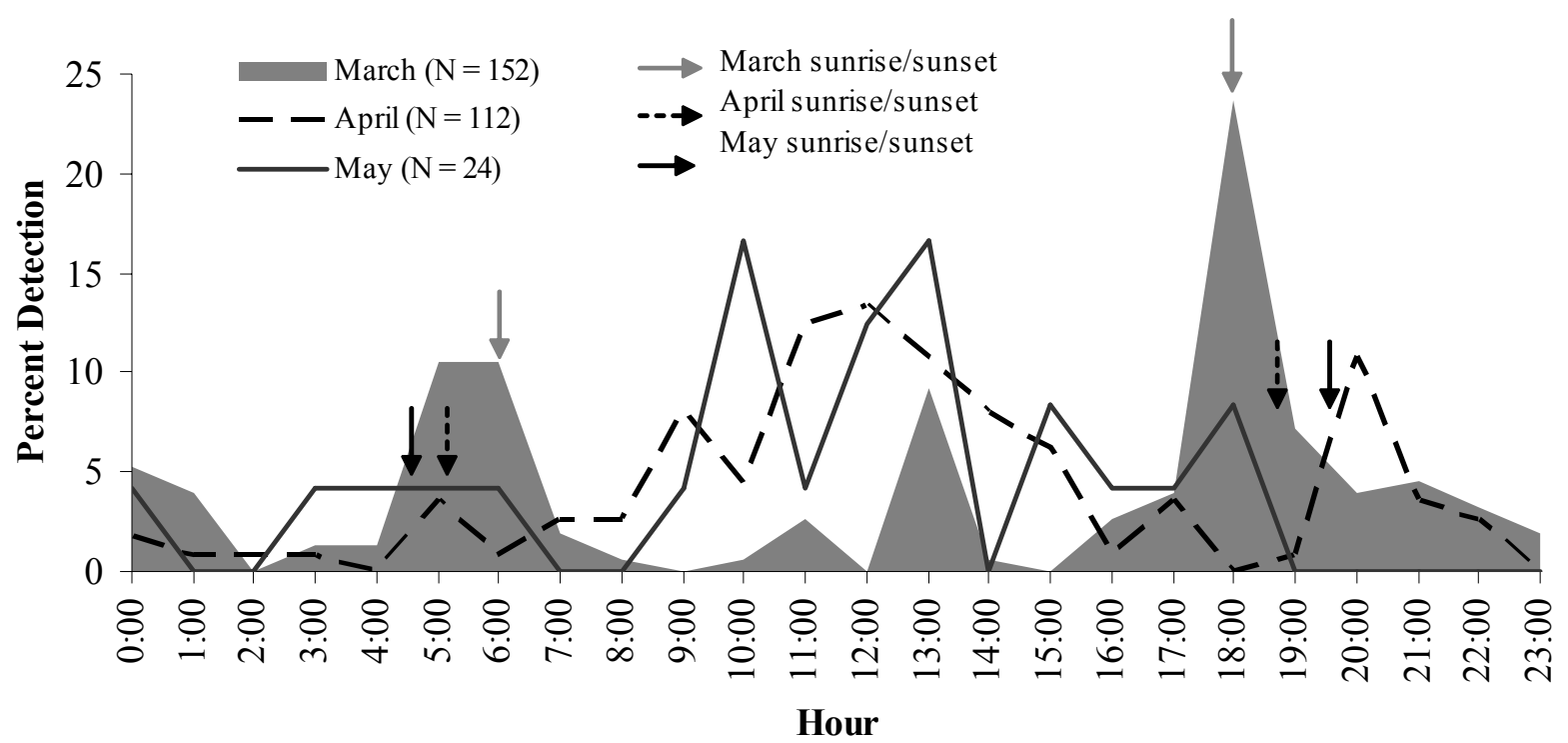

Fall Chinook Salmon

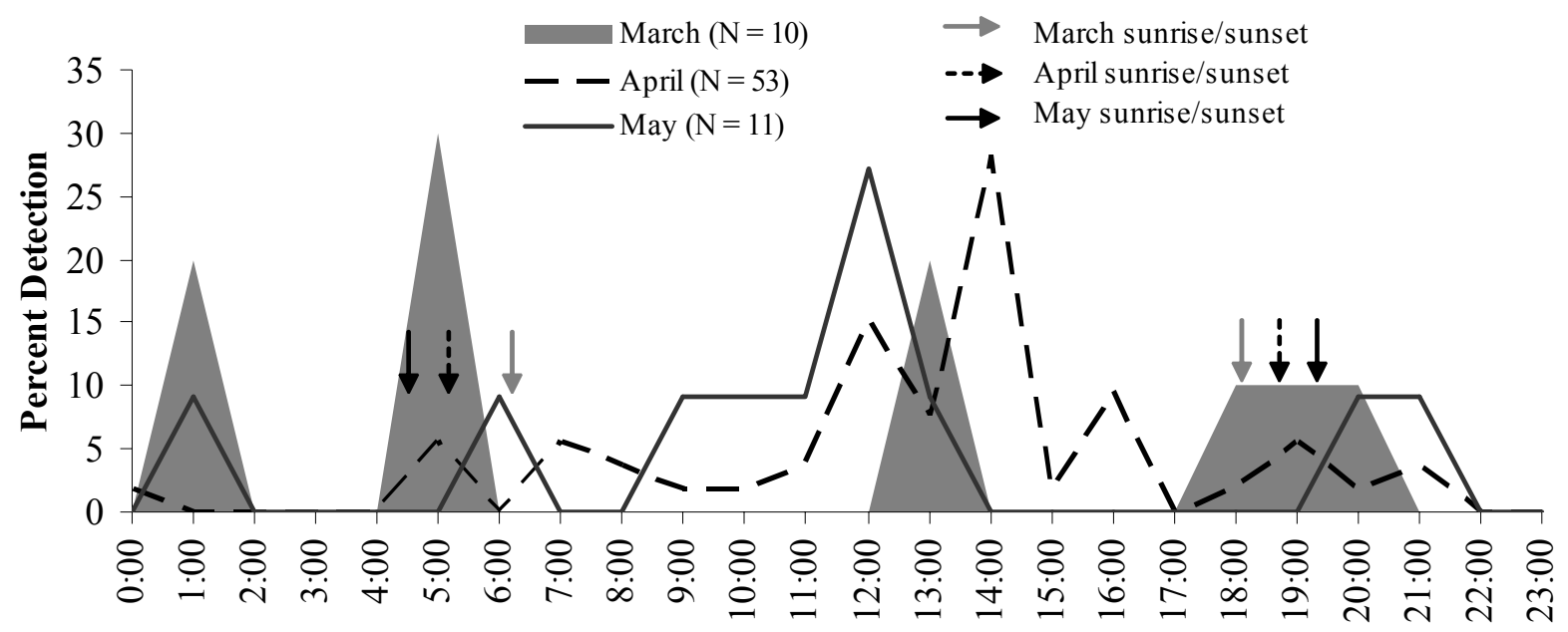

Hour

Figure 13. Diel movement of PIT-tagged hatchery yearling spring and fall chinook salmon at RM 3.7, Umatilla River, March - May 2002. 
Subyearling Fall Chinook Salmon

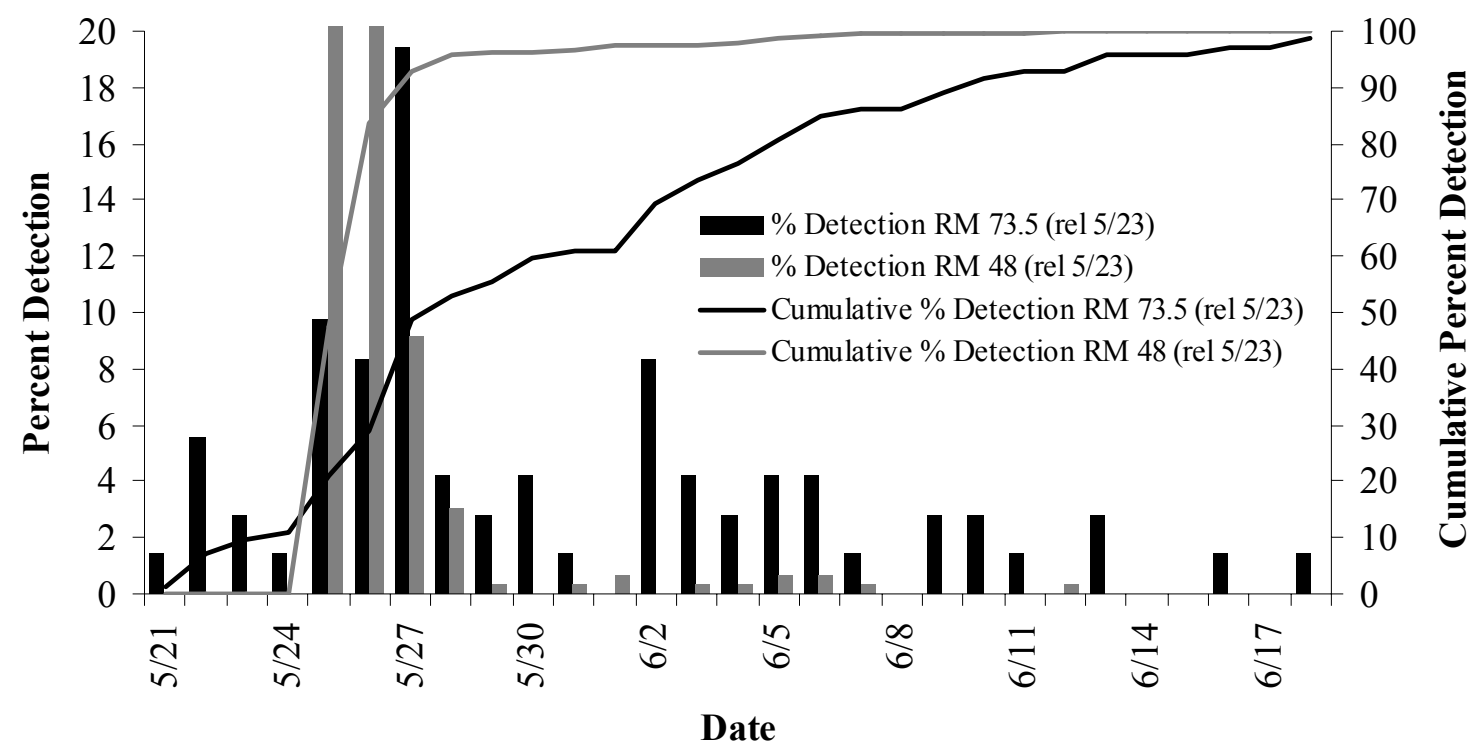

Coho Salmon

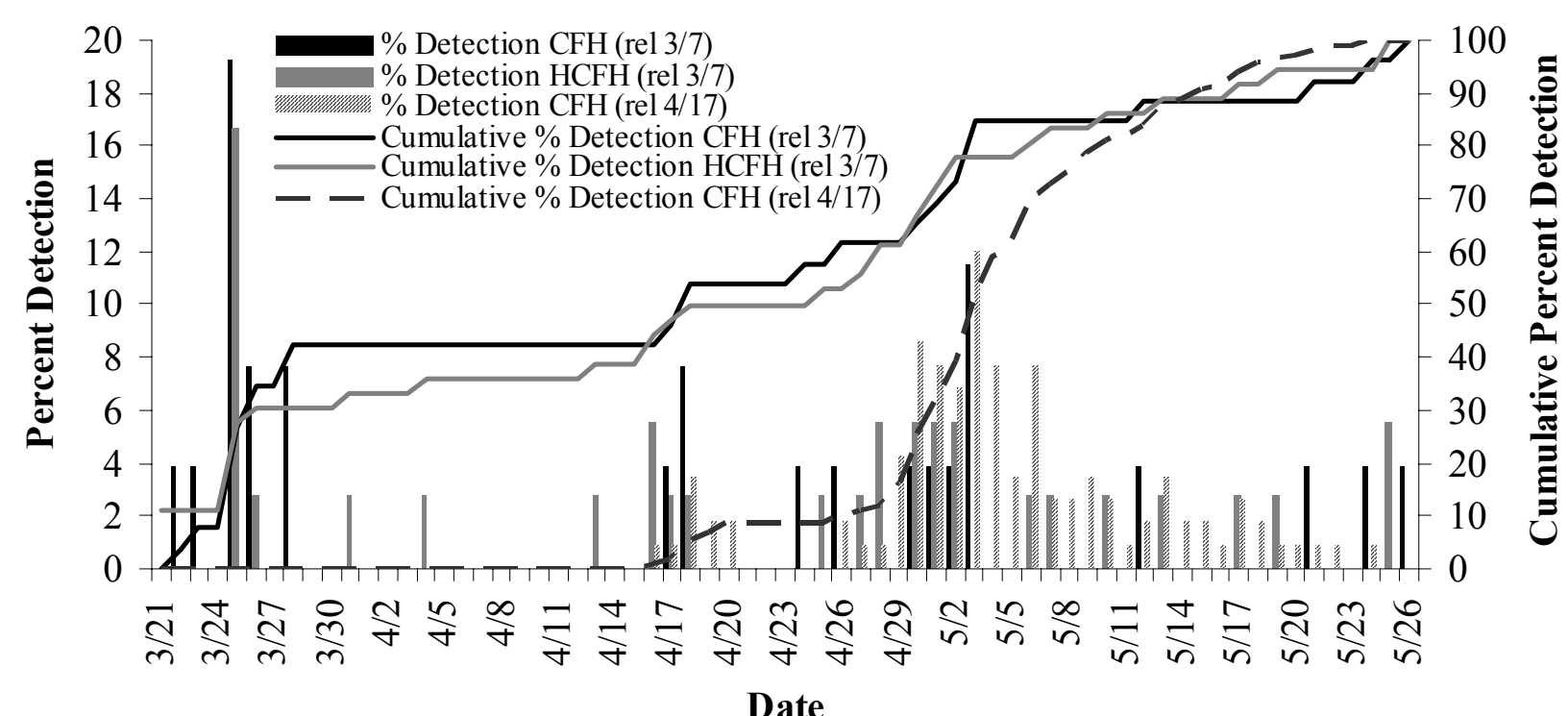

Figure 14. Percent and cumulative percent detection at RM 3.7 of PIT-tagged hatchery subyearling fall chinook and coho salmon from Carson National Fish Hatchery (CFH) and Herman Creek Fish Hatchery (HCFH), Umatilla River, March - June 2002. 


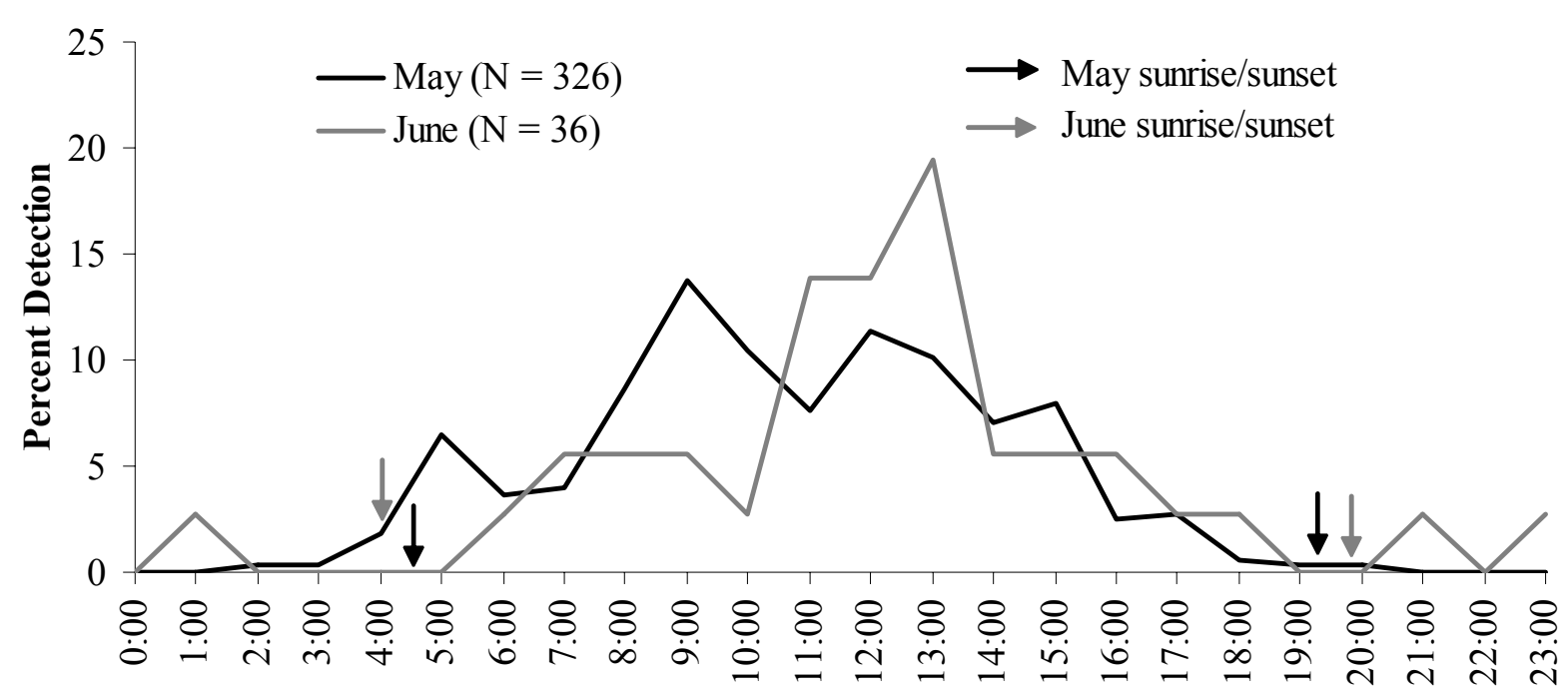

Hour

\section{Coho Salmon}

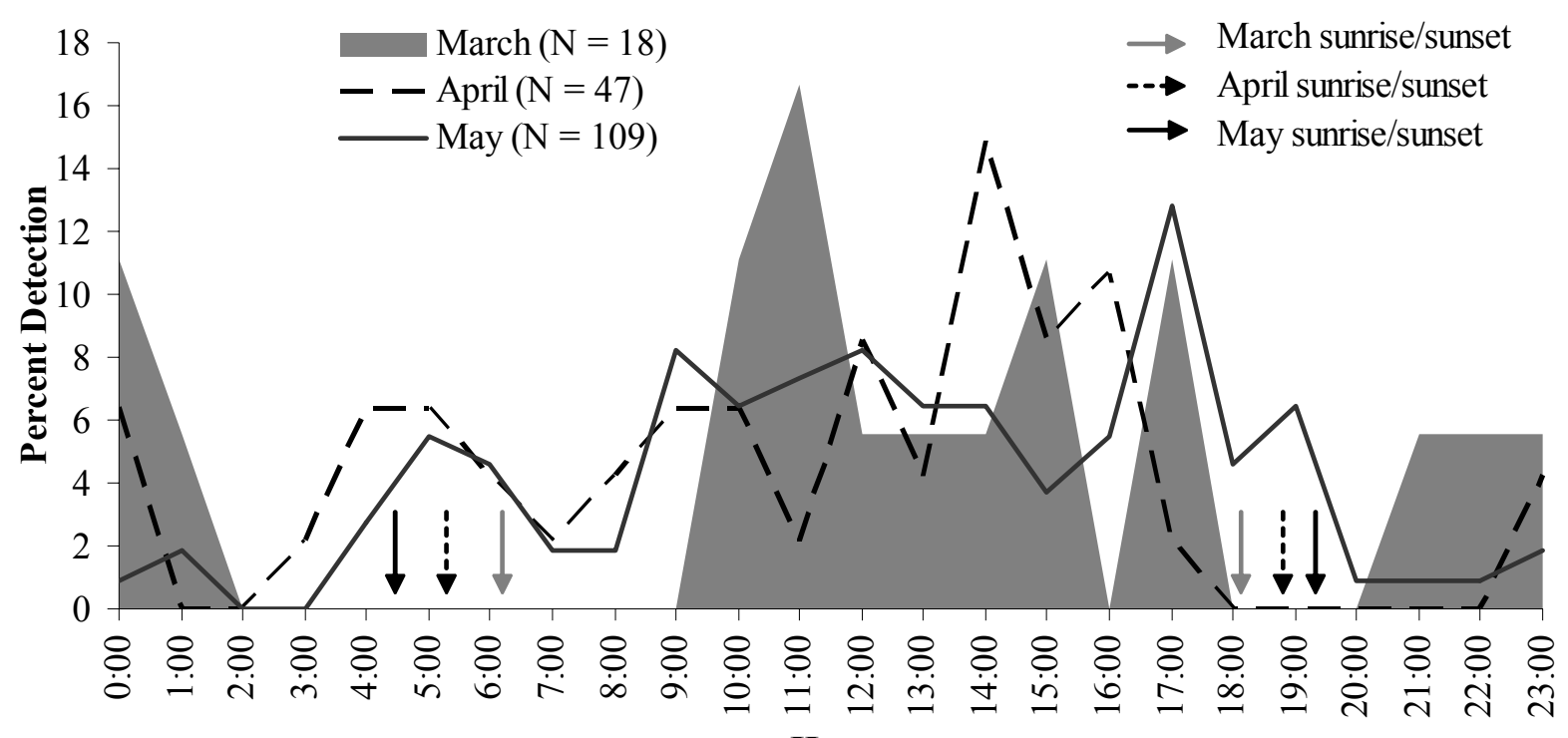

Hour

Figure 15. Diel movement of PIT-tagged hatchery subyearling fall chinook and coho salmon at RM 3.7, Umatilla River, March - June 2002. 


\section{Summer Steelhe ad (standard rearing)}

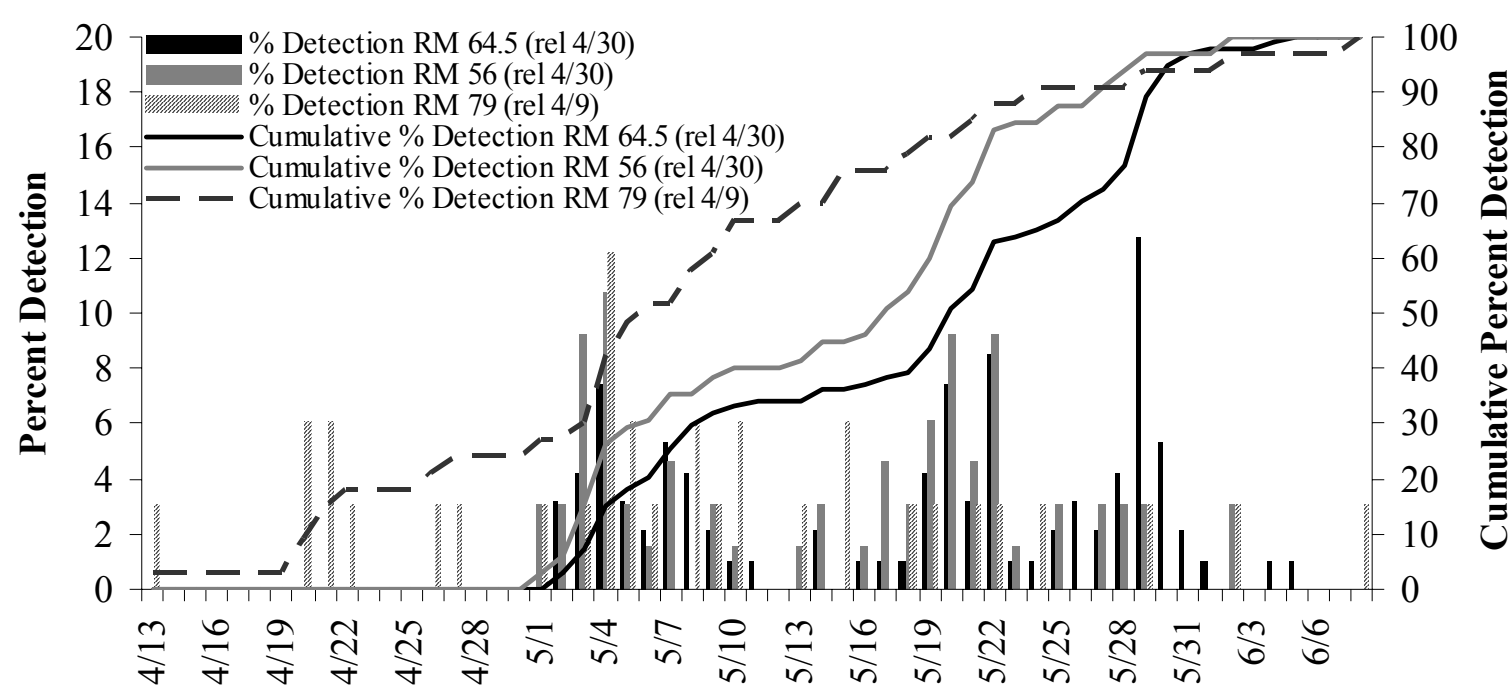

Date

Summer Steelhead (extended rearing)

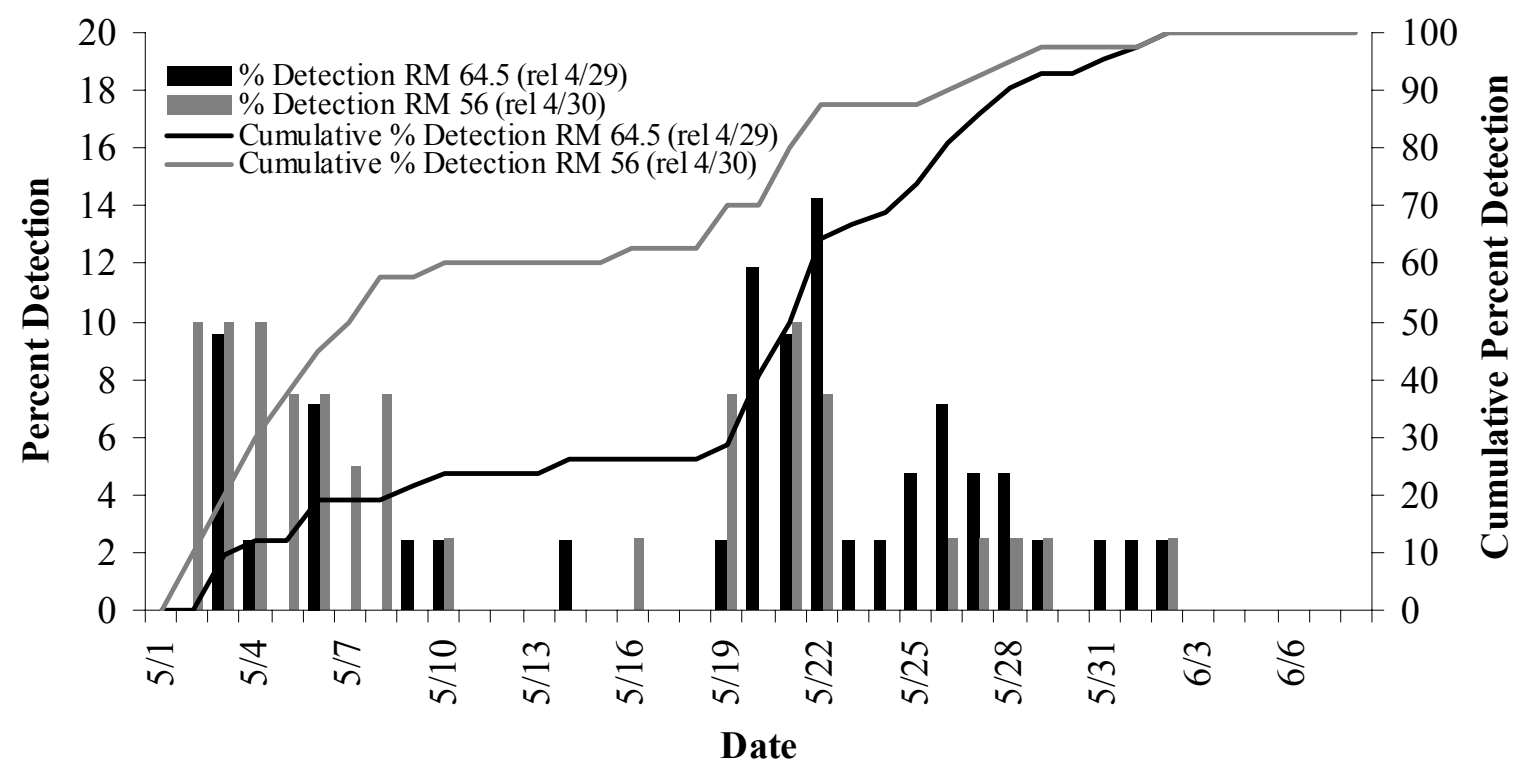

Figure 16. Percent and cumulative percent detection of PIT-tagged hatchery summer steelhead (standard and extended reared) at RM 3.7, Umatilla River, April - June 2002. 


\section{Summer Steelhead}

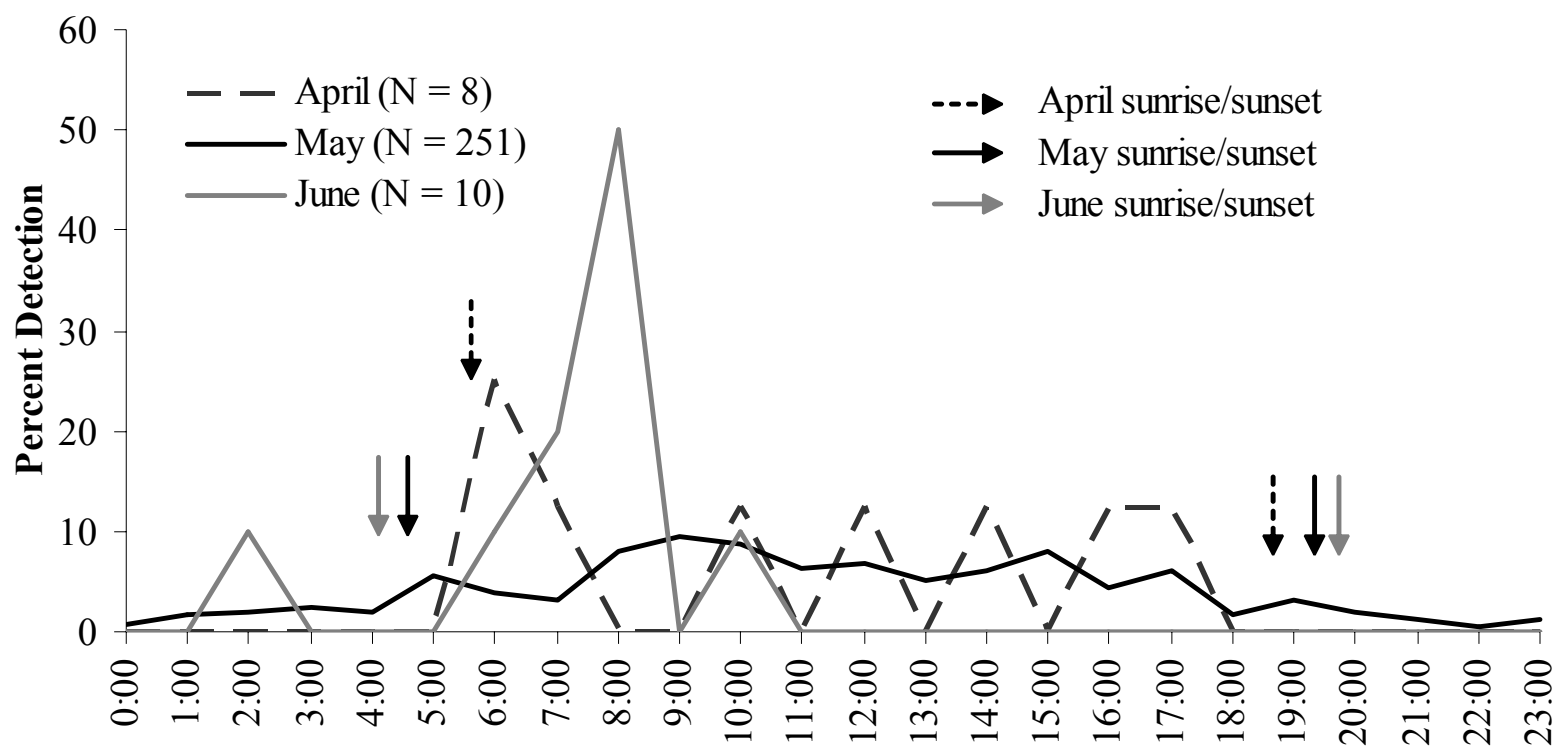

Hour

Figure 17. Diel movement of PIT-tagged hatchery summer steelhead at RM 3.7, Umatilla River, April - June 2002. 


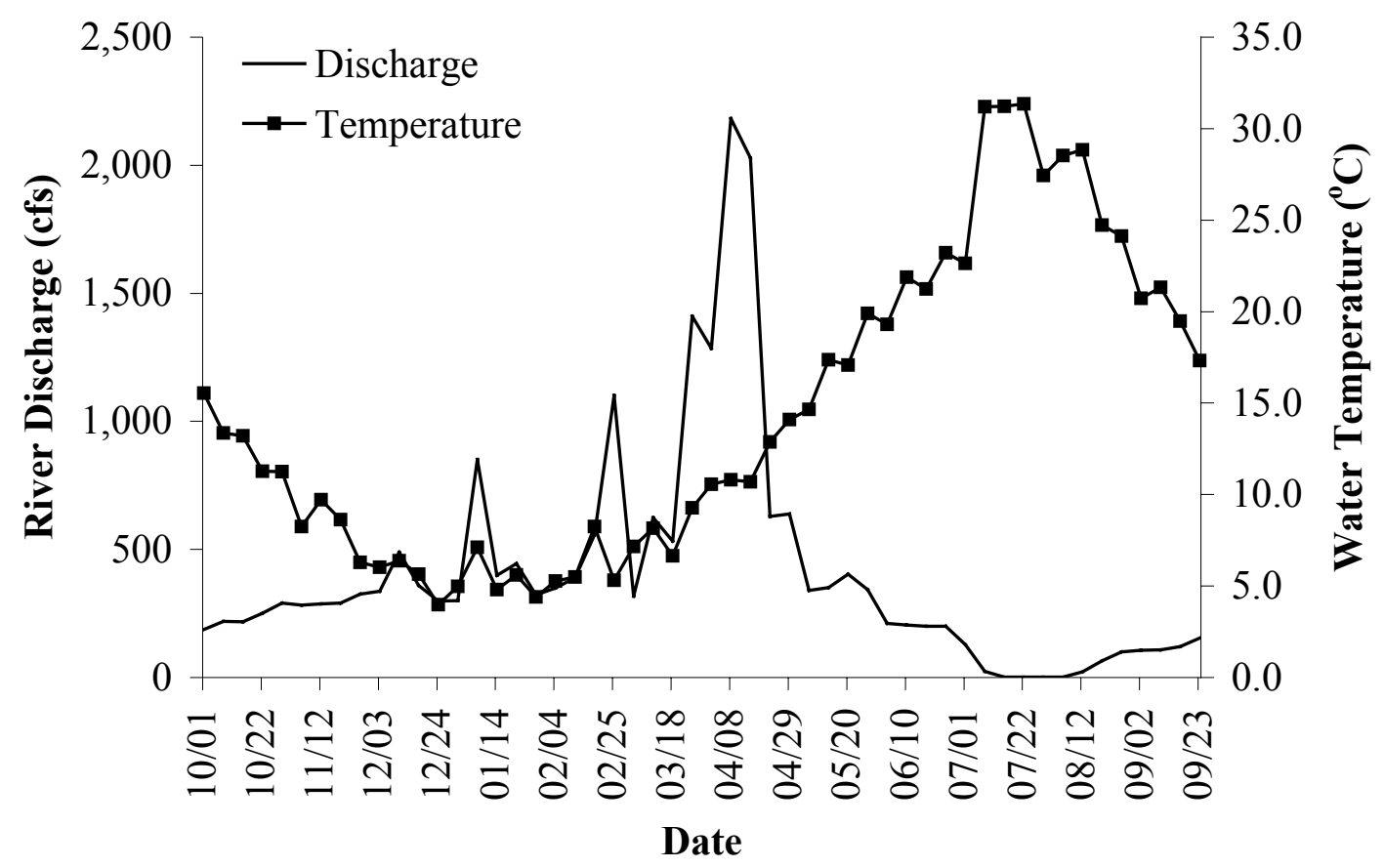

Figure 18. Mean weekly river discharge (cfs) and water temperature $\left({ }^{\circ} \mathrm{C}\right)$ at $\mathrm{RM} 2.1$, Umatilla River, October 2001 - September 2002.

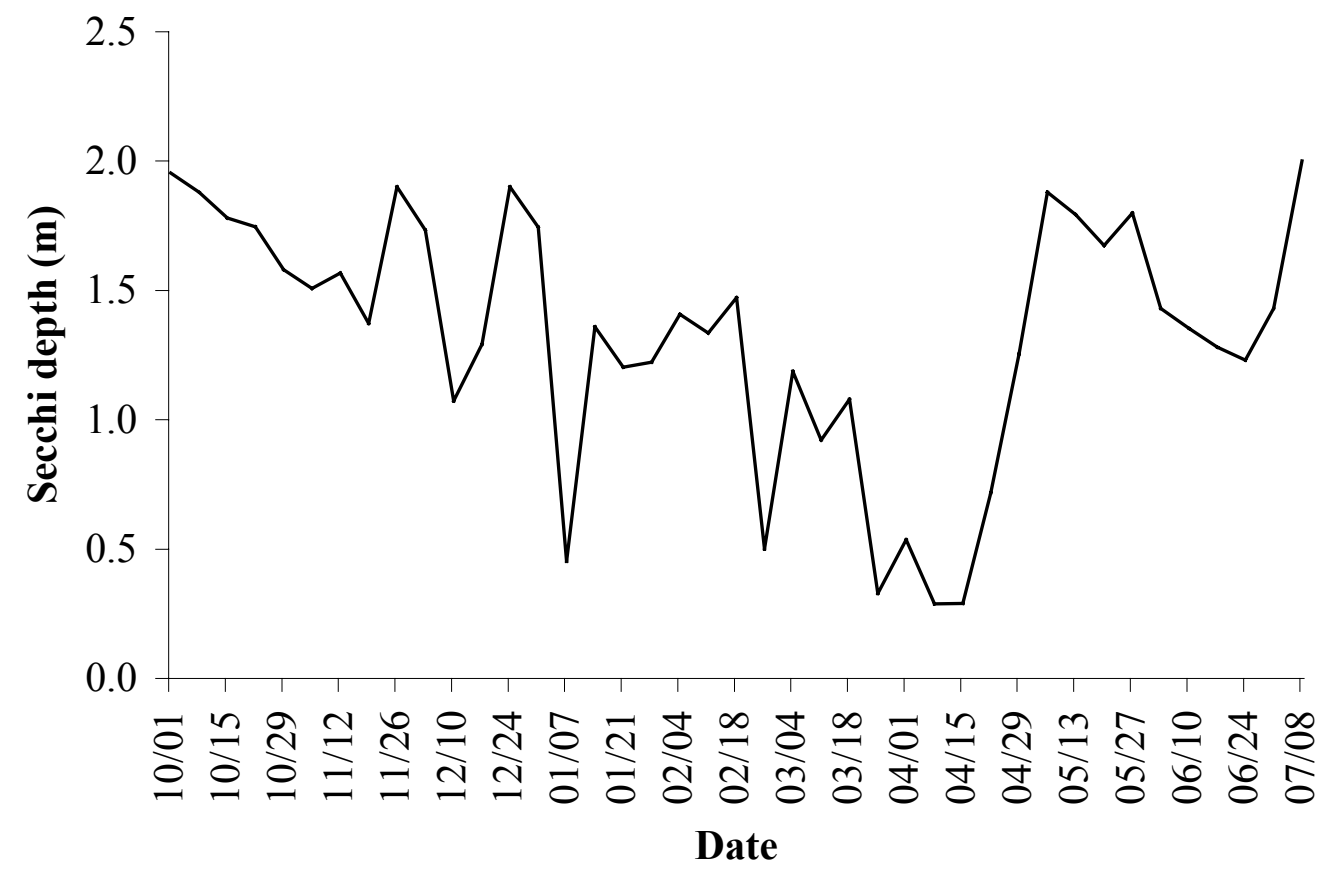

Figure 19. Mean weekly secchi depth (m) reading at RM 1.2 and 3.7, Umatilla River, October 2001 July 2002. 


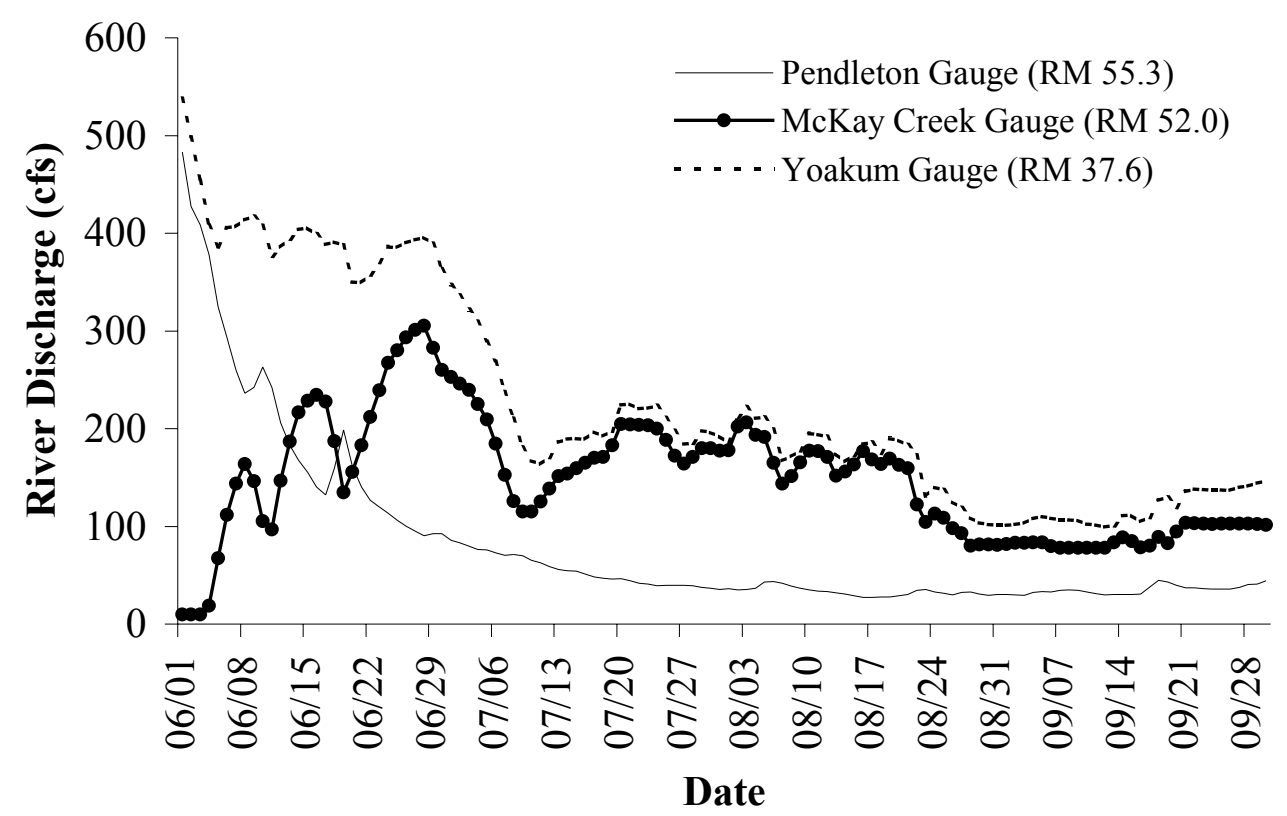

Figure 20. Mean daily discharge (cfs) of McKay Reservoir water releases and Umatilla River discharge above and below the mouth of McKay Creek, Umatilla River, June 2002 - September 2002.

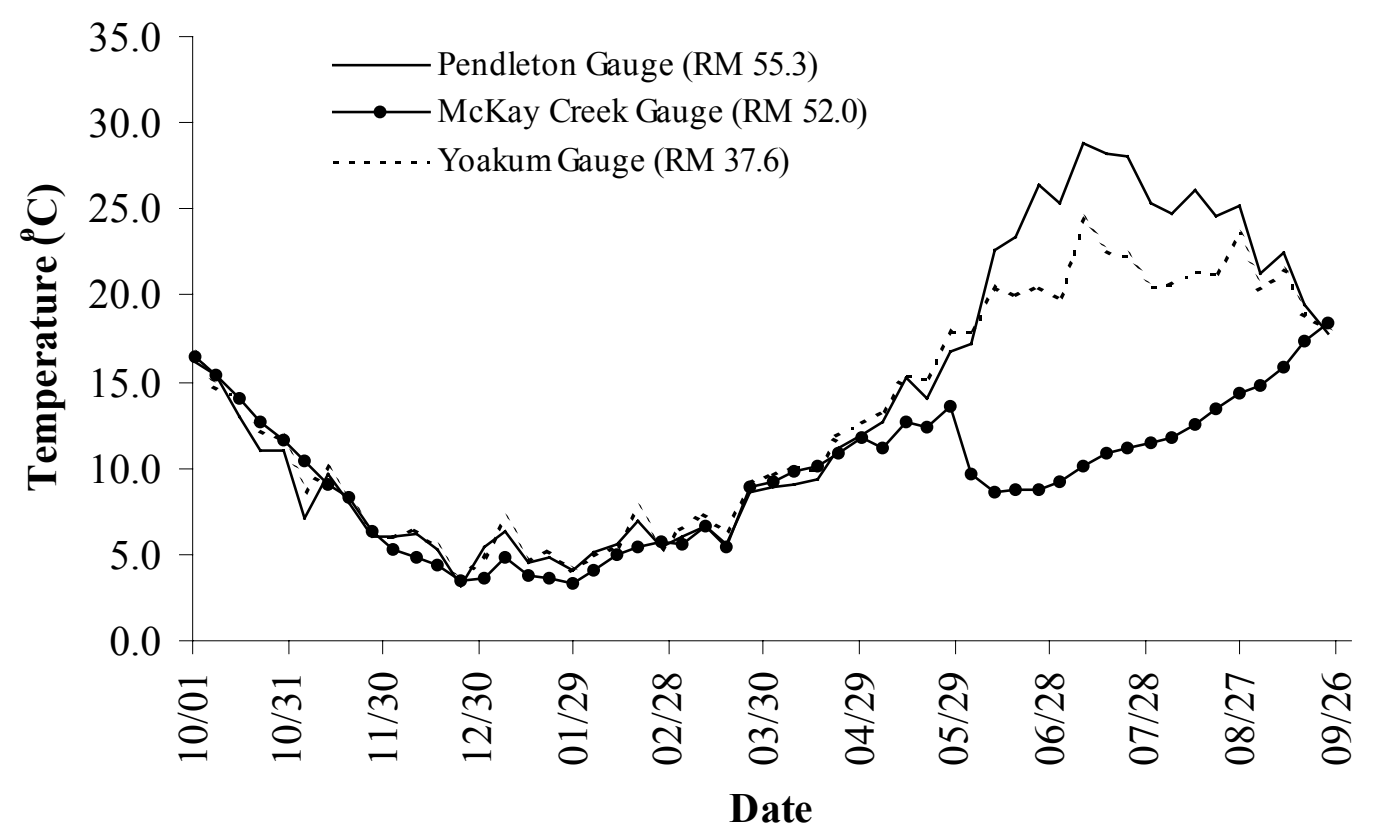

Figure 21. Mean daily water temperature $\left({ }^{\circ} \mathrm{C}\right)$ of McKay Reservoir water releases and Umatilla River water temperature above and below the mouth of McKay Creek, October 2001 - September 2002. 


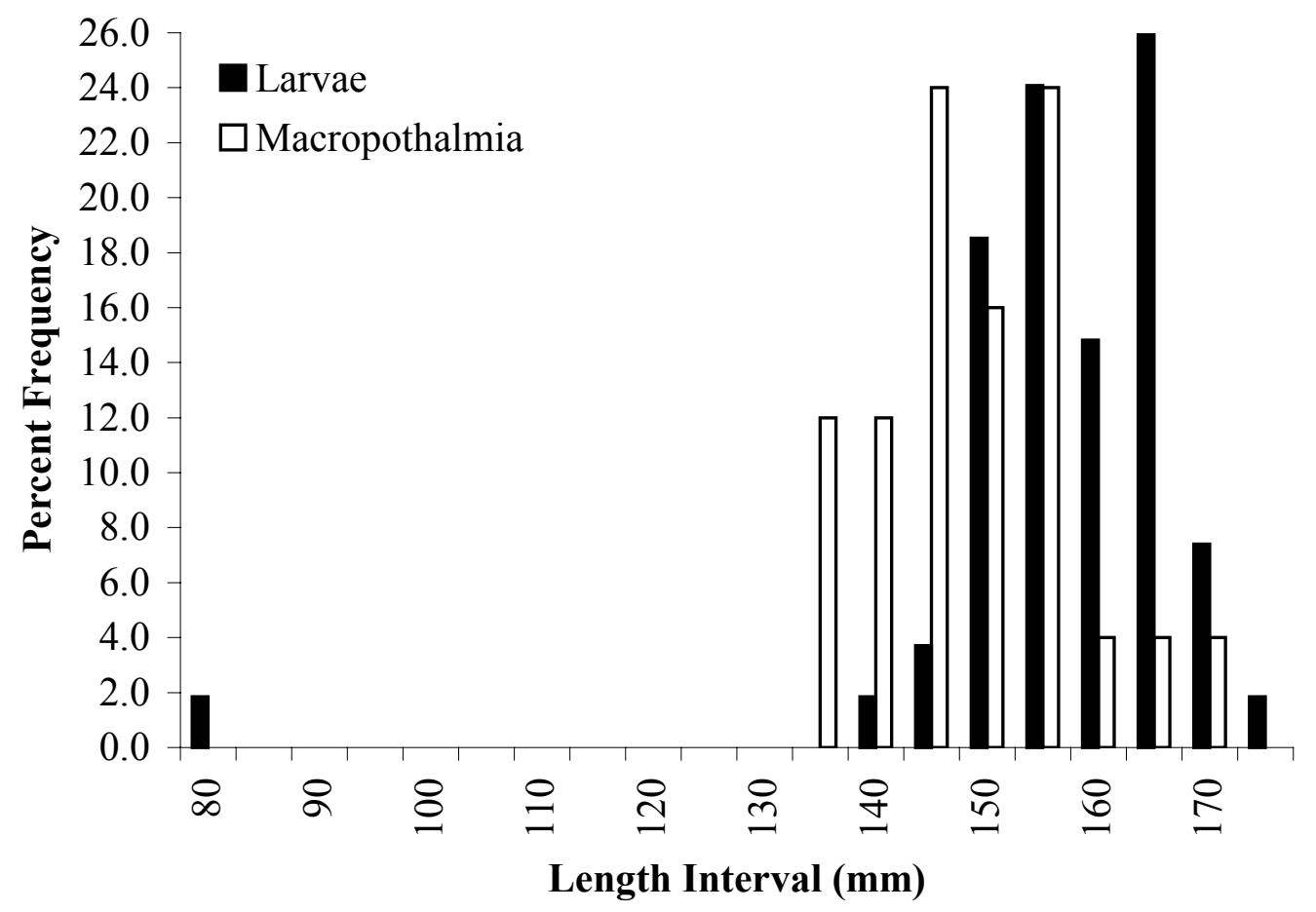

Figure 22. Length-frequency distribution of juvenile Pacific lamprey sampled at RM 1.2, Umatilla River, November 2001 - March 2002. 


\section{APPENDIX A}

Auxiliary Information from Outmigration Studies 
Appendix Table 1. Daily observations at RM 1.2, Umatilla River, October 2001 - March 2002.

Secchi depth Water temp.

Air temp..$^{c}$

Date $\quad$ Time Debris level ${ }^{a}$ Cone $^{b} \quad$ Average Maximum Minimum Maximum Minimum

\begin{tabular}{|c|c|c|c|c|c|c|c|c|}
\hline $10 / 31 / 2001$ & $14: 40$ & -- & 1.50 & -- & -- & -- & -- & -- \\
\hline $11 / 01 / 2001$ & $11: 40$ & M & 1.50 & 1.48 & -- & -- & -- & -- \\
\hline $11 / 02 / 2001$ & $13: 00$ & $\mathrm{H}$ & 2.50 & 1.38 & 53 & 54 & 48 & 63 \\
\hline $11 / 05 / 2001$ & $11: 00$ & $\mathrm{H}$ & 2.00 & 1.63 & 51 & 56 & 36 & 65 \\
\hline $11 / 07 / 2001$ & 15:00 & $\mathrm{H}$ & 1.75 & 1.48 & 44 & 52 & 26 & 62 \\
\hline $11 / 08 / 2001$ & $16: 30$ & $\mathrm{H}$ & 1.75 & 1.53 & 44 & 46 & 24 & 49 \\
\hline $11 / 10 / 2001$ & $16: 00$ & M & 2.25 & 1.40 & 43 & 44 & 26 & 31 \\
\hline $11 / 11 / 2001$ & $14: 30$ & M & 2.50 & 1.50 & 43 & 44 & 32 & 40 \\
\hline $11 / 13 / 2001$ & $11: 00$ & $\mathrm{H}$ & 2.25 & -- & 44 & 44 & 32 & 46 \\
\hline $11 / 14 / 2001$ & $12: 00$ & $\mathrm{H}$ & 2.00 & 1.83 & 46 & 47 & 47 & 64 \\
\hline $11 / 15 / 2001$ & $9: 20$ & $\mathrm{H}$ & 2.00 & 1.83 & 48 & 49 & 43 & 65 \\
\hline $11 / 16 / 2001$ & $14: 20$ & $\mathrm{M}$ & 2.00 & 1.48 & 50 & 50 & 49 & 53 \\
\hline $11 / 17 / 2001$ & $14: 35$ & $\mathrm{H}$ & 2.00 & 1.13 & 50 & 52 & 39 & 52 \\
\hline $11 / 19 / 2001$ & $14: 15$ & $\mathrm{H}$ & 2.00 & 1.53 & 47 & 52 & 32 & 48 \\
\hline $11 / 20 / 2001$ & $10: 30$ & M & 2.00 & 1.50 & 45 & 47 & 36 & 45 \\
\hline $11 / 21 / 2001$ & $10: 15$ & $\mathrm{~L}$ & 1.75 & 1.63 & 47 & 47 & 35 & 50 \\
\hline $11 / 24 / 2001$ & $12: 40$ & $\mathrm{H}$ & 2.75 & 0.83 & 45 & 50 & 32 & 57 \\
\hline $11 / 25 / 2001$ & 11:00 & M & 2.75 & -- & 44 & 46 & 37 & 50 \\
\hline $11 / 28 / 2001$ & $8: 35$ & $\mathrm{H}$ & 2.25 & 1.90 & 42 & 44 & 24 & 46 \\
\hline $11 / 29 / 2001$ & $9: 50$ & M & 2.75 & 1.90 & 40 & 41 & 34 & 42 \\
\hline $12 / 02 / 2001$ & $15: 30$ & $\mathrm{H}$ & 2.50 & 1.90 & -- & -- & 30 & 59 \\
\hline $12 / 04 / 2001$ & $14: 00$ & M & 2.75 & 1.90 & 42 & 44 & 32 & 48 \\
\hline $12 / 06 / 2001$ & $8: 00$ & -- & 2.25 & 1.70 & 43 & 43 & 33 & 50 \\
\hline $12 / 08 / 2001$ & $14: 45$ & M & 2.75 & 1.60 & 42 & 44 & 28 & 50 \\
\hline $12 / 10 / 2001$ & $14: 30$ & M & 2.75 & 1.43 & 42 & 44 & 27 & 47 \\
\hline $12 / 13 / 2001$ & $10: 20$ & $\mathrm{H}$ & 2.75 & 1.90 & 42 & 43 & 34 & 44 \\
\hline $12 / 15 / 2001$ & $12: 30$ & $\mathrm{H}$ & 5.00 & 0.23 & 40 & 45 & 27 & 54 \\
\hline $12 / 16 / 2001$ & $16: 00$ & M & 4.00 & 0.73 & 44 & 44 & 45 & 60 \\
\hline $12 / 17 / 2001$ & $10: 30$ & $\mathrm{~L}$ & 3.75 & 0.98 & 43 & 45 & 37 & 58 \\
\hline $12 / 18 / 2001$ & $11: 25$ & $\mathrm{~L}$ & 2.75 & 1.23 & 42 & 44 & 24 & 45 \\
\hline $12 / 19 / 2001$ & $10: 15$ & $\mathrm{~L}$ & 3.00 & 1.43 & 40 & 42 & 27 & 42 \\
\hline
\end{tabular}

$L=$ Low, $M=$ Medium, $H=$ High .

b $R P M=$ Rotations per minute.

$c \quad$ temp. $=$ Temperature in degrees Fahrenheit. 
Appendix Table 2. Daily observations at West Extension Canal (RM 3.7), September 2001 - October 2002.

\begin{tabular}{|c|c|c|c|c|c|c|c|c|c|c|c|c|c|c|c|c|}
\hline \multirow[b]{2}{*}{ Date } & \multirow{2}{*}{ debris $^{a}$} & \multirow{2}{*}{$\begin{array}{l}\text { River } \\
\text { Gauge }\end{array}$} & \multirow{2}{*}{$\begin{array}{l}\text { River } \\
\text { Gauge }\end{array}$} & \multirow{2}{*}{$\begin{array}{c}\text { Secchi depth } \\
\text { Average }\end{array}$} & \multirow{2}{*}{\multicolumn{2}{|c|}{$\frac{\text { Water temp. }^{b}}{\text { Minimum Maximum }}$}} & \multirow{2}{*}{\multicolumn{2}{|c|}{$\frac{\text { Air temp. }^{b}}{\text { Minimum Maximum }}$}} & \multicolumn{3}{|c|}{ Pumpback operations $^{c}$} & \multirow[b]{2}{*}{ River return } & \multicolumn{3}{|c|}{ Headgate opening $^{d}$} & \multirow[b]{2}{*}{ Phase } \\
\hline & & & & & & & & & $\mathrm{P} 1$ & $\mathrm{P} 2$ & $\mathrm{P} 3$ & & $\mathrm{~S}$ & M & $\mathrm{N}$ & \\
\hline 10/01/2001 11:00 & M & 404.4 & 404.5 & 2.03 & 59 & 61 & 43 & 74 & off & off & off & 5.0 & -- & -- & -- & off \\
\hline 10/02/2001 11:45 & $\mathrm{L}$ & 404.4 & 404.5 & 2.00 & 59 & 61 & 47 & 77 & off & off & off & 5.0 & -- & -- & -- & off \\
\hline $10 / 05 / 2001 \quad 8: 00$ & $\mathrm{~L}$ & 404.4 & 404.5 & 1.83 & 57 & 60 & 40 & 63 & off & off & off & 5.0 & -- & -- & -- & off \\
\hline $10 / 08 / 200114: 45$ & M & 404.4 & 404.5 & 1.88 & 56 & 56 & 42 & 69 & off & off & off & 5.0 & -- & -- & -- & off \\
\hline 10/10/2001 11:30 & $\mathrm{L}$ & 404.4 & 404.5 & 1.93 & 55 & 58 & 38 & 66 & off & off & off & 5.0 & -- & -- & -- & off \\
\hline $10 / 12 / 2001 \quad 17: 20$ & $\mathrm{~L}$ & 404.4 & 404.5 & -- & 54 & 56 & 46 & 65 & off & off & off & 5.0 & 27.5 & 34.5 & 34.0 & off \\
\hline $10 / 14 / 2001$ 15:00 & $\mathrm{L}$ & 404.4 & 404.5 & 1.83 & 54 & 55 & 52 & 70 & off & off & off & 5.0 & 27.5 & 34.5 & 34.0 & off \\
\hline 10/17/2001 16:00 & $\mathrm{L}$ & 404.4 & 404.5 & 1.63 & 56 & 56 & 42 & 70 & off & off & off & 5.0 & -- & -- & -- & off \\
\hline 10/20/2001 14:30 & $\mathrm{L}$ & 404.4 & 404.5 & 1.93 & 54 & 55 & 42 & 70 & off & off & off & 5.0 & -- & -- & -- & off \\
\hline 10/22/2001 11:20 & $\mathrm{L}$ & 404.4 & 404.5 & 1.78 & 54 & 54 & 42 & 63 & off & off & off & 5.0 & -- & -- & -- & off \\
\hline $10 / 24 / 200110: 45$ & $\mathrm{~L}$ & 404.4 & 404.5 & 1.83 & 52 & 53 & 42 & 62 & off & off & off & 5.0 & 27.5 & 34.5 & 34.0 & off \\
\hline 10/27/2001 16:00 & $\mathrm{L}$ & 404.5 & 404.5 & 1.63 & 50 & 51 & 41 & 62 & off & off & off & 5.0 & -- & -- & -- & off \\
\hline 10/29/2001 11:20 & $\mathrm{L}$ & 404.5 & 404.5 & -- & 50 & 52 & 38 & 54 & off & off & off & 5.0 & -- & -- & -- & off \\
\hline 10/30/2001 14:00 & $\mathrm{L}$ & 404.5 & 404.5 & 1.88 & 50 & 50 & 46 & 47 & off & off & off & 5.0 & -- & -- & -- & off \\
\hline 03/08/2002 10:00 & $\mathrm{L}$ & 404.5 & 404.1 & -- & -- & -- & -- & -- & off & off & off & 7.0 & 0.0 & 0.0 & 26.0 & off \\
\hline 03/09/2002 13:45 & $\mathrm{L}$ & 404.5 & 404.1 & -- & 40 & 48 & 33 & 51 & off & off & off & 7.0 & 0.0 & 0.0 & 26.0 & off \\
\hline 03/10/2002 14:00 & $\mathrm{L}$ & 404.5 & 404.1 & 1.20 & 42 & 44 & 34 & 46 & off & off & off & 7.0 & 0.0 & 0.0 & 26.0 & off \\
\hline 03/12/2002 16:00 & $\mathrm{L}$ & 404.5 & 404.0 & 1.10 & 43 & 50 & 40 & 63 & off & off & off & 7.0 & 0.0 & 0.0 & 26.0 & off \\
\hline 03/13/2002 14:15 & $\mathrm{L}$ & 404.9 & 404.5 & 0.55 & 47 & 50 & 37 & 57 & off & off & off & 7.0 & 0.0 & 0.0 & 26.5 & off \\
\hline 03/14/2002 12:00 & $\mathrm{L}$ & 404.9 & 404.5 & 0.55 & 43 & 47 & 40 & 55 & off & off & off & 7.0 & 0.0 & 0.0 & 26.5 & off \\
\hline 03/15/2002 12:15 & $\mathrm{L}$ & 404.8 & 404.3 & 0.78 & 42 & 45 & 33 & 56 & off & off & off & 7.0 & 0.0 & 0.0 & 24.0 & off \\
\hline 03/16/2002 13:41 & $\mathrm{L}$ & 404.8 & 404.2 & 1.65 & 42 & 45 & 41 & 55 & off & off & off & 7.0 & 0.0 & 0.0 & 24.0 & off \\
\hline 03/17/2002 9:50 & $\mathrm{L}$ & 404.7 & 404.2 & 0.90 & 40 & 44 & 22 & 47 & off & off & off & 7.0 & 0.0 & 0.0 & 24.0 & off \\
\hline 03/18/2002 14:35 & $\mathrm{L}$ & 404.6 & 404.1 & 1.13 & 41 & 42 & 28 & 46 & off & off & off & 7.0 & -- & -- & -- & off \\
\hline 03/19/2002 12:00 & $\mathrm{L}$ & 404.6 & 404.1 & 1.23 & 40 & 44 & 43 & 55 & off & off & off & 7.0 & 0.0 & 0.0 & 24.0 & off \\
\hline
\end{tabular}

a $L=$ Low, $M=$ Moderate, $H=$ High.

temp. = Temperature in degrees Fahrenheit.

c Pumpback operation for three pumps (P1, P2, P3) in the pumpback bay.

d Headgate openings (inches) are for: $S=$ south gate, $M=$ middle gate, $N=$ north gate. 
Appendix Table 2. Continued.

\begin{tabular}{|c|c|c|c|c|c|c|c|c|c|c|c|c|c|c|c|c|}
\hline \multirow[b]{2}{*}{ Date } & \multirow[b]{2}{*}{ Debris $^{a}$} & \multirow{2}{*}{$\begin{array}{l}\text { River } \\
\text { gauge }\end{array}$} & \multirow{2}{*}{$\begin{array}{l}\text { River } \\
\text { gauge }\end{array}$} & \multirow{2}{*}{$\begin{array}{c}\text { Secchi depth } \\
\text { Average }\end{array}$} & \multirow{2}{*}{\multicolumn{2}{|c|}{$\frac{\text { Water temp. }^{b}}{\text { Minimum Maximum }}$}} & \multirow{2}{*}{\multicolumn{2}{|c|}{$\frac{\text { Air temp. }}{\text { Minimum Maximum }^{b}}$}} & \multicolumn{3}{|c|}{ Pumpback operations ${ }^{c}$} & \multirow[b]{2}{*}{ River return } & \multicolumn{4}{|c|}{ Headgate opening $^{d}$} \\
\hline & & & & & & & & & P1 & $\mathrm{P} 2$ & P3 & & $\mathrm{S}$ & $\mathrm{M}$ & $\mathrm{N}$ & Phase 1 \\
\hline 03/20/2002 13:00 & M & 404.7 & 404.2 & 1.10 & 42 & 44 & 38 & 59 & off & off & off & 7.0 & 0.0 & 0.0 & 24.0 & off \\
\hline 03/21/2002 11:15 & M & 404.6 & 404.2 & 0.95 & 40 & 44 & 32 & 42 & off & off & off & 7.0 & 16.0 & 15.5 & 16.0 & off \\
\hline 03/22/2002 15:30 & $\mathrm{L}$ & 404.6 & 404.0 & 1.08 & 39 & 44 & 29 & 50 & off & off & off & 5.0 & 16.0 & 15.5 & 16.0 & off \\
\hline 03/23/2002 12:45 & $\mathrm{L}$ & 404.7 & 404.1 & 0.88 & 41 & 44 & 31 & 49 & off & off & off & 5.0 & 16.0 & 15.5 & 16.0 & off \\
\hline 03/24/2002 9:45 & $\mathrm{L}$ & 404.6 & 404.0 & 1.18 & 42 & 44 & 40 & 50 & off & off & off & 5.0 & 16.0 & 15.5 & 16.0 & off \\
\hline 03/25/2002 12:00 & $\mathrm{H}$ & 405.6 & 404.2 & 0.25 & 42 & 46 & 42 & 60 & off & off & off & 5.0 & 11.0 & 10.0 & 10.0 & off \\
\hline 03/26/2002 9:30 & M & 405.6 & 404.0 & 0.13 & 44 & 47 & 36 & 62 & off & off & off & 5.0 & 11.0 & 10.0 & 10.0 & off \\
\hline 03/27/2002 13:20 & $\mathrm{L}$ & 405.4 & 403.9 & 0.23 & 44 & 48 & 41 & 62 & off & off & off & 5.0 & 11.0 & 10.0 & 10.0 & off \\
\hline 03/28/2002 15:30 & $\mathrm{L}$ & 405.2 & 404.0 & 0.33 & 44 & 51 & 44 & 61 & off & off & off & 5.0 & 10.0 & 9.5 & 10.0 & off \\
\hline 03/29/2002 14:50 & $\mathrm{L}$ & 405.1 & 403.9 & 0.38 & 45 & 51 & 40 & 62 & off & off & off & 5.0 & 10.0 & 10.0 & 10.0 & off \\
\hline 03/30/2002 16:45 & $\mathrm{L}$ & 405.0 & 403.9 & 0.48 & 47 & 53 & 45 & 67 & off & off & off & 5.0 & 10.0 & 10.0 & 10.0 & off \\
\hline 03/31/2002 9:30 & $\mathrm{L}$ & 405.0 & 403.9 & 0.50 & 47 & 55 & 41 & 67 & off & off & off & 5.0 & 10.0 & 10.0 & 10.0 & off \\
\hline 04/01/2002 12:00 & $\mathrm{L}$ & 405.0 & 404.0 & 0.48 & 49 & 53 & 47 & 70 & off & off & off & 5.0 & 10.0 & 10.0 & 10.0 & off \\
\hline 04/02/2002 17:00 & $\mathrm{L}$ & 405.0 & 403.5 & 0.48 & 46 & 52 & 41 & 65 & off & off & off & 5.0 & 11.5 & 11.5 & 11.5 & off \\
\hline 04/03/2002 13:50 & $\mathrm{L}$ & 405.0 & 403.6 & 0.58 & 45 & 50 & 30 & 61 & off & off & off & 5.0 & 11.5 & 11.5 & 11.5 & off \\
\hline 04/04/2002 14:50 & $\mathrm{L}$ & 404.9 & 403.1 & 0.68 & 46 & 56 & 32 & 69 & off & off & off & 5.0 & 15.5 & 15.5 & 15.5 & off \\
\hline 04/05/2002 15:00 & $\mathrm{L}$ & 404.9 & 404.1 & 0.63 & 48 & 51 & 40 & 70 & off & off & off & 5.0 & 17.0 & 17.0 & 17.5 & off \\
\hline 04/06/2002 11:45 & $\mathrm{L}$ & 405.0 & 404.2 & 0.58 & 48 & 51 & 45 & 68 & off & off & off & 5.0 & 17.0 & 17.0 & 17.0 & off \\
\hline 04/07/2002 11:00 & $\mathrm{L}$ & 405.2 & 404.3 & 0.33 & 47 & 52 & 50 & 68 & off & off & off & 5.0 & 14.0 & 14.0 & 14.0 & off \\
\hline 04/09/2002 12:40 & $\mathrm{L}$ & 405.1 & 404.0 & 0.53 & 48 & 50 & 36 & 67 & off & off & off & 5.0 & 14.0 & 14.0 & 14.0 & off \\
\hline 04/10/2002 12:00 & $\mathrm{L}$ & 405.2 & 404.1 & 0.53 & 48 & 51 & 48 & 63 & off & off & off & 5.0 & 14.0 & 14.0 & 14.0 & off \\
\hline 04/11/2002 12:30 & M & 405.5 & 404.0 & 0.23 & 48 & 50 & 48 & 69 & off & off & off & 5.0 & 12.0 & 12.0 & 12.0 & off \\
\hline 04/12/2002 13:00 & $\mathrm{L}$ & 405.6 & 404.1 & 0.18 & 50 & 53 & 49 & 72 & off & off & off & 5.0 & 12.0 & 12.0 & 12.0 & off \\
\hline 04/13/2002 14:15 & $\mathrm{L}$ & 405.8 & 404.0 & 0.13 & 50 & 54 & 52 & 74 & off & off & off & 5.0 & 11.0 & 11.0 & 11.0 & off \\
\hline 04/14/2002 10:00 & $\mathrm{L}$ & 405.8 & 404.0 & 0.13 & 48 & 56 & 48 & 74 & off & off & off & 5.0 & 11.0 & 11.0 & 11.0 & off \\
\hline 04/15/2002 11:00 & $\mathrm{L}$ & 406.4 & 404.4 & 0.25 & 44 & 51 & 42 & 58 & off & off & off & 7.0 & 9.0 & 9.0 & 9.0 & off \\
\hline 04/16/2002 12:30 & $\mathrm{L}$ & 405.8 & 404.0 & 0.08 & 42 & 47 & 42 & 61 & off & off & off & 7.0 & 11.5 & 11.5 & 11.5 & off \\
\hline 04/17/2002 9:30 & $\mathrm{L}$ & 405.3 & 404.0 & 0.13 & 44 & 47 & 40 & 59 & off & off & off & 7.0 & 13.5 & 13.5 & 13.5 & off \\
\hline 04/18/2002 18:00 & $\mathrm{L}$ & 404.7 & 404.8 & 0.28 & 46 & 50 & 34 & 68 & off & off & off & 7.0 & 14.5 & 14.5 & 14.5 & off \\
\hline
\end{tabular}


Appendix Table 2. Continued.

\begin{tabular}{|c|c|c|c|c|c|c|c|c|c|c|c|c|c|c|c|c|}
\hline \multirow[b]{2}{*}{ Date } & \multirow[b]{2}{*}{ Debris $^{a}$} & \multirow{2}{*}{$\begin{array}{l}\text { River } \\
\text { gauge }\end{array}$} & \multirow{2}{*}{$\begin{array}{l}\text { River } \\
\text { gauge }\end{array}$} & \multirow{2}{*}{$\begin{array}{c}\text { Secchi depth } \\
\text { Average } \\
\end{array}$} & \multirow{2}{*}{\multicolumn{2}{|c|}{$\frac{\text { Water temp. }{ }^{b}}{\text { Minimum Maximum }}$}} & \multirow{2}{*}{\multicolumn{2}{|c|}{$\frac{\text { Air temp. }}{\text { Minimum Maximum }^{b}}$}} & \multicolumn{3}{|c|}{ Pumpback operations ${ }^{c}$} & \multirow[b]{2}{*}{ River Return } & \multicolumn{4}{|c|}{ Headgate opening $^{d}$} \\
\hline & & & & & & & & & $\mathrm{P} 1$ & $\mathrm{P} 2$ & $\mathrm{P} 3$ & & $\mathrm{~S}$ & $\mathrm{M}$ & $\mathrm{N}$ & Phase 1 \\
\hline 04/19/2002 12:00 & $\mathrm{L}$ & 404.7 & 404.1 & 0.33 & 46 & 50 & 37 & 60 & off & off & off & 7.0 & 18.0 & 18.0 & 18.0 & off \\
\hline 04/21/2002 11:30 & $\mathrm{L}$ & 404.5 & 404.0 & 0.53 & 48 & 56 & 50 & 78 & off & off & off & 7.0 & 23.0 & 23.0 & 22.5 & off \\
\hline 04/22/2002 11:00 & $\mathrm{L}$ & 404.6 & 403.9 & 0.63 & -- & -- & -- & -- & off & off & off & 7.0 & -- & -- & -- & off \\
\hline 04/23/2002 12:10 & $\mathrm{L}$ & 404.5 & 403.9 & 0.68 & 50 & 57 & 38 & 70 & off & off & off & 5.0 & 23.0 & 23.0 & 22.5 & off \\
\hline 04/24/2002 15:45 & $\mathrm{L}$ & 405.5 & 404.0 & 0.78 & 50 & 54 & 34 & 68 & off & off & off & 5.0 & 25.0 & 25.0 & 25.0 & off \\
\hline 04/25/2002 11:10 & $\mathrm{L}$ & 404.4 & 404.0 & 0.78 & 50 & 55 & 50 & 68 & off & off & off & 5.0 & 25.0 & 25.0 & 25.0 & off \\
\hline 04/26/2002 15:30 & $\mathrm{L}$ & 404.5 & 404.1 & 0.88 & 49 & 56 & 40 & 72 & off & off & off & 5.0 & 26.0 & 26.0 & 26.0 & off \\
\hline 04/27/2002 11:50 & $\mathrm{L}$ & 404.5 & 404.1 & 0.78 & 52 & 57 & 46 & 70 & off & off & off & 5.0 & 26.0 & 26.0 & 26.0 & off \\
\hline 04/28/2002 8:00 & $\mathrm{L}$ & 404.5 & 404.1 & 0.49 & 51 & 57 & 37 & 74 & off & off & off & 6.5 & 26.0 & 26.0 & 26.0 & off \\
\hline 04/30/2002 15:30 & $\mathrm{L}$ & 404.5 & 404.2 & 1.23 & 54 & 57 & 40 & 74 & off & off & off & 5.0 & 29.0 & 29.0 & 29.0 & off \\
\hline 05/01/2002 $16: 30$ & $\mathrm{~L}$ & 404.5 & 404.2 & 1.28 & 55 & 60 & 46 & 76 & off & off & off & 5.0 & 30.0 & 30.0 & 30.0 & off \\
\hline 05/02/2002 16:45 & $\mathrm{L}$ & 404.5 & 404.1 & 1.18 & 56 & 60 & 44 & 75 & off & off & off & 5.0 & 30.0 & 30.0 & 30.0 & off \\
\hline 05/03/2002 15:30 & $\mathrm{L}$ & 404.6 & 404.1 & 1.23 & 53 & 60 & 44 & 69 & off & off & off & 5.0 & 30.0 & 30.0 & 30.0 & off \\
\hline 05/04/2002 16:20 & $\mathrm{L}$ & 404.5 & 404.2 & 1.28 & 50 & 57 & 41 & 67 & off & off & off & 5.0 & 31.0 & 31.0 & 31.0 & off \\
\hline 05/05/2002 12:45 & $\mathrm{L}$ & 404.5 & 404.1 & 1.33 & 50 & 54 & 47 & 64 & off & off & off & 5.0 & 31.0 & 31.0 & 31.0 & off \\
\hline 05/07/2002 14:00 & $\mathrm{L}$ & 404.4 & 404.1 & 1.98 & 50 & 53 & 42 & 64 & off & off & off & 7.0 & 30.0 & 30.0 & 30.0 & off \\
\hline 05/08/2002 17:00 & $\mathrm{L}$ & 404.3 & 404.1 & 1.88 & 50 & 55 & 36 & 66 & off & off & off & 5.0 & 32.5 & 32.5 & 32.5 & off \\
\hline 05/09/2002 12:10 & $\mathrm{L}$ & 404.3 & 404.3 & 1.98 & 52 & 57 & 46 & 68 & off & off & off & 5.0 & 23.0 & 23.0 & 23.0 & on \\
\hline 05/10/2002 11:20 & $\mathrm{L}$ & 404.4 & 404.3 & 1.68 & 53 & 60 & 44 & 70 & off & off & off & 5.0 & 23.0 & 23.0 & 23.0 & on \\
\hline 05/11/2002 14:00 & $\mathrm{L}$ & 404.4 & 404.3 & 1.88 & 53 & 61 & 41 & 78 & off & off & off & 5.0 & 20.0 & 19.5 & 20.0 & on \\
\hline 05/12/2002 13:00 & $\mathrm{L}$ & 404.4 & 404.3 & 1.88 & 57 & 64 & 43 & 79 & off & off & off & 5.0 & 20.0 & 19.5 & 20.0 & on \\
\hline 05/15/2002 18:45 & $\mathrm{L}$ & 404.4 & 404.1 & 1.83 & 55 & 65 & 46 & 86 & off & off & off & 5.0 & 34.0 & 34.0 & 34.0 & off \\
\hline 05/16/2002 16:30 & $\mathrm{L}$ & 404.5 & 404.1 & 1.83 & 58 & 63 & 44 & 77 & off & off & off & 5.0 & 34.0 & 34.0 & 34.0 & off \\
\hline 05/17/2002 15:25 & $\mathrm{L}$ & 404.4 & 404.1 & 1.88 & 60 & 64 & 53 & 79 & off & off & off & 5.0 & 35.5 & 35.5 & 35.5 & off \\
\hline 05/18/2002 14:30 & $\mathrm{L}$ & 404.3 & 404.1 & 1.63 & 59 & 65 & 52 & 80 & off & off & off & 5.0 & 35.5 & 35.5 & 35.5 & off \\
\hline 05/20/2002 15:40 & $\mathrm{L}$ & 404.5 & 404.2 & 1.43 & 60 & 64 & 56 & 80 & off & off & off & 5.0 & 31.0 & 31.0 & 31.0 & off \\
\hline 05/21/2002 16:00 & $\mathrm{L}$ & 404.5 & 404.2 & 1.28 & 57 & 62 & 43 & 71 & off & off & off & 5.0 & 31.0 & 31.0 & 31.0 & off \\
\hline 05/22/2002 12:45 & $\mathrm{L}$ & 404.5 & 404.2 & 1.48 & 55 & 59 & 50 & 70 & off & off & off & 5.0 & 31.0 & 31.0 & 31.0 & off \\
\hline
\end{tabular}


Appendix Table 2. Continued.

\begin{tabular}{|c|c|c|c|c|c|c|c|c|c|c|c|c|c|c|c|c|}
\hline \multirow[b]{2}{*}{ Date } & \multirow[b]{2}{*}{ Debris $^{a}$} & \multirow{2}{*}{$\begin{array}{l}\text { River } \\
\text { gauge }\end{array}$} & \multirow{2}{*}{$\begin{array}{l}\text { River } \\
\text { gauge }\end{array}$} & \multirow{2}{*}{$\frac{\text { Secchi depth }}{\text { Average }}$} & \multirow{2}{*}{\multicolumn{2}{|c|}{$\frac{\text { Water temp. }^{b}}{\text { Minimum Maximum }}$}} & \multirow{2}{*}{\multicolumn{2}{|c|}{$\frac{\text { Air temp. }{ }^{b}}{\text { Minimum Maximum }}$}} & \multicolumn{3}{|c|}{ Pumpback operations $^{c}$} & \multirow[b]{2}{*}{ River Return } & \multicolumn{3}{|c|}{ Headgate opening $^{d}$} & \multirow[b]{2}{*}{ Phase 1} \\
\hline & & & & & & & & & $\mathrm{P} 1$ & $\mathrm{P} 2$ & $\mathrm{P} 3$ & & $\mathrm{~S}$ & $\mathrm{M}$ & $\mathrm{N}$ & \\
\hline 05/23/2002 14:00 & $\mathrm{L}$ & 404.4 & 404.1 & 1.88 & 55 & 59 & 51 & 73 & off & off & off & 5.0 & 31.0 & 31.0 & 31.0 & off \\
\hline 05/24/2002 13:30 & $\mathrm{L}$ & 404.4 & 404.1 & 1.88 & 57 & 62 & 46 & 75 & off & off & off & 5.0 & 31.0 & 31.0 & 31.0 & off \\
\hline 05/26/2002 18:15 & $\mathrm{L}$ & 404.3 & 404.0 & 1.88 & 60 & 66 & 50 & 82 & off & off & off & 5.0 & 36.0 & 36.0 & 36.0 & off \\
\hline 05/28/2002 13:00 & $\mathrm{L}$ & 404.4 & 404.1 & 1.88 & 63 & 68 & 57 & 84 & off & off & off & 5.0 & 40.0 & 40.0 & 40.0 & off \\
\hline 05/29/2002 15:30 & $\mathrm{L}$ & 404.4 & 404.1 & 1.88 & 63 & 68 & 60 & 81 & off & off & off & 5.0 & 40.0 & 40.0 & 40.0 & off \\
\hline 05/30/2002 13:00 & $\mathrm{L}$ & 404.4 & 404.3 & 1.88 & -- & -- & -- & -- & off & off & off & 5.0 & 40.0 & 40.0 & 40.0 & off \\
\hline 06/07/2002 12:30 & M & 404.4 & 404.3 & 1.28 & 61 & 67 & 44 & 75 & off & off & off & 7.0 & 18.0 & 18.0 & 18.0 & on \\
\hline 06/11/2002 13:00 & $\mathrm{L}$ & 404.4 & 404.4 & 1.45 & 61 & 66 & 45 & 80 & off & off & off & 7.0 & 18.0 & 18.0 & 18.0 & on \\
\hline 06/12/2002 12:00 & $\mathrm{L}$ & 404.4 & 404.3 & 1.38 & 64 & 70 & 65 & 84 & off & off & off & 7.0 & 18.0 & 18.0 & 18.0 & on \\
\hline 06/14/2002 10:00 & $\mathrm{L}$ & 404.4 & 404.3 & 1.23 & 67 & 71 & 64 & 94 & off & off & off & 7.0 & 18.0 & 18.0 & 18.0 & on \\
\hline 06/18/2002 15:00 & $\mathrm{L}$ & 404.4 & 404.4 & 1.23 & 64 & 73 & 63 & 100 & off & off & off & 7.0 & 18.0 & 18.0 & 18.0 & on \\
\hline 06/22/2002 8:00 & $\mathrm{L}$ & 404.4 & 404.3 & 1.33 & 64 & 72 & 50 & 92 & off & off & off & 7.0 & 18.0 & 18.0 & 18.0 & on \\
\hline 06/26/2002 13:30 & M & 404.4 & 404.3 & 1.33 & 64 & 70 & -- & -- & off & off & off & 7.0 & 18.0 & 18.0 & 18.0 & on \\
\hline 06/28/2002 12:00 & M & 404.4 & 404.3 & 1.13 & 70 & 76 & -- & -- & off & off & off & 7.0 & 18.0 & 18.0 & 18.0 & on \\
\hline 07/02/2002 15:00 & $\mathrm{L}$ & 404.4 & 404.4 & 1.43 & 68 & 72 & -- & -- & off & off & off & 0.0 & 36.0 & 36.0 & 36.0 & -- \\
\hline 07/09/2002 12:00 & $\mathrm{L}$ & -- & 404.4 & 2.00 & 66 & 72 & 53 & 97 & off & off & off & 0.0 & 36.0 & 36.0 & 36.0 & -- \\
\hline 09/23/2002 9:30 & $\mathrm{L}$ & 404.4 & 404.4 & 2.10 & -- & -- & -- & -- & off & off & off & 3.0 & -- & -- & --- & on \\
\hline 09/26/2002 11:00 & $\mathrm{L}$ & 403.4 & 404.4 & 2.10 & 54 & 62 & 46 & 92 & off & off & off & 5.0 & -- & -- & -- & on \\
\hline
\end{tabular}


Appendix Table 3. ANOVA testing with transformed data for differences in juvenile survival between various release groups of hatchery spring chinook salmon, fall chinook salmon, and summer steelhead; outmigration years 1999-2002.

\section{Spring Chinook Salmon}

Cold Water Reared (Overwintered) vs. Standard Reared

\begin{tabular}{llll}
\hline Source & df & F & p-value $^{a}$ \\
\hline Outmigration Year & 1 & 0.99 & 0.768 \\
Release & 4 & &
\end{tabular}

Michigan vs. Oregon Raceways

\begin{tabular}{llll}
\hline Source & df & F & p-level \\
\hline Release & 1 & 0.12 & 0.747 \\
Outmigration Year & 4 & &
\end{tabular}

Fall Chinook Salmon

Early vs. Late Release

\begin{tabular}{llll}
\hline Source & df & F & p-level \\
\hline Release & 1 & 0.003 & 0.959 \\
Outmigration Year & 4 & &
\end{tabular}

\begin{tabular}{|c|c|c|c|}
\hline Source & $\mathrm{df}$ & $\mathrm{F}$ & p-level \\
\hline Release & 1 & 1.78 & 0.253 \\
\hline Outmigration Year & 4 & & \\
\hline
\end{tabular}

Minthorn vs. Bonifer Springs

\begin{tabular}{llll}
\hline Source & df & F & p-level \\
\hline $\begin{array}{l}\text { Release } \\
\text { Outmigration Year }\end{array}$ & 1 & 2.14 & 0.217 \\
& & & \\
Early vs. Late Release & & & p-level \\
\hline Source & df & F & 0.066 \\
\hline $\begin{array}{l}\text { Release } \\
\text { Outmigration Year }\end{array}$ & 1 & 0.232 & \\
\hline
\end{tabular}

a Significant $p=<0.05$. 
Appendix Table 4. Summary of annual abundance estimates of natural juvenile salmonids emigrating the Umatilla River, 1997-2002.

\begin{tabular}{lllllll} 
Species & 1997 & 1998 & 1999 & 2000 & 2001 & 2002 \\
\hline NCH & 1,433 & 259,593 & 20,292 & 46,764 & 37,697 & 45,289 \\
NSTS & 21,861 & 59,182 & 46,530 & 81,759 & 33,844 & 77,016 \\
NCOH $^{a}$ & 331 & 6,258 & 1,557 & 30,163 & 9,444 & 4,444 \\
\hline
\end{tabular}

a Estimate doesn't account for unmarked fish, which are indistinguishable between hatchery and natural. 